IZA DP No. 6423

The Shadow Economy and Work in the Shadow: What Do We (Not) Know?

Friedrich Schneider

March 2012 


\title{
The Shadow Economy and Work in the Shadow: What Do We (Not) Know?
}

\author{
Friedrich Schneider \\ Johannes Kepler University of Linz \\ and IZA
}

\author{
Discussion Paper No. 6423 \\ March 2012
}

\author{
IZA \\ P.O. Box 7240 \\ 53072 Bonn \\ Germany \\ Phone: +49-228-3894-0 \\ Fax: +49-228-3894-180 \\ E-mail: iza@iza.org
}

\begin{abstract}
Any opinions expressed here are those of the author(s) and not those of IZA. Research published in this series may include views on policy, but the institute itself takes no institutional policy positions.

The Institute for the Study of Labor (IZA) in Bonn is a local and virtual international research center and a place of communication between science, politics and business. IZA is an independent nonprofit organization supported by Deutsche Post Foundation. The center is associated with the University of Bonn and offers a stimulating research environment through its international network, workshops and conferences, data service, project support, research visits and doctoral program. IZA engages in (i) original and internationally competitive research in all fields of labor economics, (ii) development of policy concepts, and (iii) dissemination of research results and concepts to the interested public.
\end{abstract}

IZA Discussion Papers often represent preliminary work and are circulated to encourage discussion. Citation of such a paper should account for its provisional character. A revised version may be available directly from the author. 


\section{ABSTRACT \\ The Shadow Economy and Work in the Shadow: What Do We (Not) Know?}

In this paper the main focus lies on the shadow economy and on work in the shadow in OECD, developing and transition countries. Besides informal employment in the rural and non-rural sector also other measures of informal employment like the share of employees not covered by social security, own account workers or unpaid family workers are shown. The most influential factors on the shadow economy and/or shadow labor force are tax policies and state regulation, which, if they rise, increase both. Furthermore the discussion of the recent micro studies underline that economic opportunities, the overall burden of the state (taxes and regulations), the general situation on the labor market, and unemployment are crucial for an understanding of the dynamics of the shadow economy and especially the shadow labor force.

JEL Classification: K42, H26, D78

Keywords: shadow economy, undeclared work, shadow labor force, tax morale, tax pressure, state regulation, labor market

Corresponding author:

Friedrich Schneider

Department of Economics

Johannes Kepler University of Linz

Altenbergerstr. 69

4040 Linz

Austria

E-mail: friedrich.schneider@jku.at 


\section{INTRODUCTION}

Fighting tax evasion, the shadow economy and informal (illegal) employment have been important policy goals in OECD countries during recent decades. In order to do this one should have knowledge about the size and development of the shadow economy and shadow economy labor force as well as the reasons why people are engaged in shadow economy activities. Hence, in this paper I am mainly concerned with the size and development of the shadow economy, black activities or undeclared work, and the shadow economy labor force. Tax evasion is not considered in order to keep the subject of this paper tractable and because too many additional aspects would be involved ${ }^{1}$. Also tax morale or experimental studies on tax compliance are beyond the scope of this paper².

My paper is organized as follows: Section 2 presents theoretical considerations about the definition and measurement of the shadow economy and discusses also the main factors determining its size. In Section 3 the empirical results of the size and development of the shadow economy are discussed. In section 4 first two micro studies of the shadow economy labor force are described and then a detailed discussion of the size and development of the shadow economy labor force and its various aspects is undertaken. In section 5 the interaction between the shadow economy and unemployment is analyzed. In section 6 the adjustments of shadow economy measures in national accounts are presented. Finally section 7 concludes.

\section{SOME THEORETICAL CONSIDERATIONS ABOUT THE SHA- DOW ECONOMY}

\subsection{Defining the Shadow Economy}

Most authors trying to measure the shadow economy still face the difficulty of a precise definition of the shadow economy. ${ }^{3}$ According to one commonly used definition it comprises all

1. See Andreoni, Erard and Feinstein (1998) for the authoritative survey, Feld and Frey (2007) or Kirchler (2007) for broader interdisciplinary approaches, or the papers by Kirchler, Maciejovsky and Schneider (2003), Kastlunger, Kirchler, Mittore and Pitters (2009), Kirchler, Hoelzl and Wahl (2007).

2. The authoritative scientific work on tax morale is by Torgler (2007). See also Torgler (2002) for a survey on experimental studies and Blackwell (2009) for a meta-analysis.

3. My paper focuses on the size and development of the shadow economy for uniform countries and not for specific regions. Recently first studies have been undertaken to measure the size of the shadow economy as well as the "grey" or "shadow" labor force for urban regions or states (e.g. California). See e.g. Marcelli, Pastor and Joassart (1999), Marcelli (2004), Chen (2004), Williams and Windebank (1998, 2001a, b), Flaming, Hayolamak, and Jossart (2005), Alderslade, Talmage and Freeman (2006), Brück, HaistenDeNew and Zimmermann (2006). Herwartz, Schneider and Tafenau (2009) and Tafenau, Herwartz and Schneider (2010) estimate the size of the shadow economy of 234 EU-NUTS regions for the year 2004 for the first time demonstrating a considerable regional variation in the size of the shadow economy. 
currently unregistered economic activities that contribute to the officially calculated Gross National Product. ${ }^{4}$ Smith (1994, p. 18) defines it as "market-based production of goods and services, whether legal or illegal, that escapes detection in the official estimates of GDP”. Put differently, one of the broadest definitions is: “...those economic activities and the income derived from them that circumvent or otherwise avoid government regulation, taxation or observation". 5 As these definitions still leave room for interpretation, Table 2.1 provides a further understanding as to what could be a reasonable consensus definition of the underground (or shadow) economy.

Table 2.1: A Taxonomy of Types of Underground Economic Activities ${ }^{1)}$

\begin{tabular}{|c|c|c|c|c|}
\hline Type of Activity & \multicolumn{2}{|c|}{ Monetary Transactions } & \multicolumn{2}{|c|}{ Non Monetary Transactions } \\
\hline $\begin{array}{l}\text { ILLEGAL ACTIV- } \\
\text { ITIES }\end{array}$ & \multicolumn{2}{|c|}{$\begin{array}{l}\text { Trade with stolen goods; drug dealing } \\
\text { and manufacturing; prostitution; } \\
\text { gambling; smuggling; fraud, human-, } \\
\text { drug-, and weapon-trafficking }\end{array}$} & \multicolumn{2}{|c|}{$\begin{array}{l}\text { Barter of drugs, stolen goods, } \\
\text { smuggling etc. Produce or growing } \\
\text { drugs for own use. Theft for own } \\
\text { use. }\end{array}$} \\
\hline & Tax Evasion & Tax Avoidance & Tax Evasion & Tax Avoidance \\
\hline $\begin{array}{l}\text { LEGAL ACTIVI- } \\
\text { TIES }\end{array}$ & $\begin{array}{l}\text { Unreported in- } \\
\text { come from self- } \\
\text { employment; } \\
\text { wages, salaries } \\
\text { and assets from } \\
\text { unreported work } \\
\text { related to legal } \\
\text { services and } \\
\text { goods }\end{array}$ & $\begin{array}{l}\text { Employee dis- } \\
\text { counts, fringe } \\
\text { benefits }\end{array}$ & $\begin{array}{l}\text { Barter of legal } \\
\text { services and } \\
\text { goods }\end{array}$ & $\begin{array}{l}\text { All do-it-yourself } \\
\text { work and neigh- } \\
\text { bor help }\end{array}$ \\
\hline
\end{tabular}

From Table 2.1, it is obvious that a broad definition of the shadow economy includes unreported income from the production of legal goods and services, either from monetary or barter transactions - and so includes all productive economic activities that would generally be taxable were they reported to the state $(\operatorname{tax})$ authorities.

4. This definition is used, e.g., by Feige (1989, 1994), Schneider (1994a, 2003, 2005) and Frey and Pommerehne (1984). Do-it-yourself activities are not included. For estimates of the shadow economy and the doit-yourself activities for Germany see Bühn, Karmann und Schneider (2009) or Karmann (1986, 1990).

5. This definition is taken from Del'Anno (2003), Del'Anno and Schneider (2004) and Feige (1989); see also Thomas (1999), Fleming, Roman and Farrell (2000) or Feld and Larsen (2005, p. 25). 
In this paper the following more narrow definition of the shadow economy is used. ${ }^{6}$ The shadow economy includes all market-based legal production of goods and services that are deliberately concealed from public authorities for the following reasons:

1. to avoid payment of income, value added or other taxes,

2. to avoid payment of social security contributions,

3. to avoid having to meet certain legal labor market standards, such as minimum wages, maximum working hours, safety standards, etc., and

4. to avoid complying with certain administrative obligations, such as completing statistical questionnaires or other administrative forms.

Thus, I will not deal with typically illegal underground economic activities that fit the characteristics of classical crimes like burglary, robbery, drug dealing, etc. I also exclude the informal household economy which consists of all household services and production.

\subsection{Measuring the Shadow Economy ${ }^{7}$}

The definition of the shadow economy plays an important role in assessing its size. By having a clear definition, a number of ambiguities and controversies can be avoided. In general, there are two types of shadow economic activities: illicit employment and the production of goods and services mostly consumed within the household. ${ }^{8}$ The following analysis focuses on both types, but tries to exclude illegal activities such as drug production, crime and human trafficking. The production of goods and services, consumed within the household, or childcare are not part of this analysis either. Thus, it only focuses on productive economic activities that would normally be included in the national accounts but which remain underground due to tax or regulatory burdens. ${ }^{9}$ Although such legal activities contribute to the country's value added, they are not captured in the national accounts because they are produced in illicit ways (e.g. by people without proper qualification or without a master craftsman's certificate) ${ }^{10}$. From the economic and social perspective, soft forms of illicit employment, such as moonlighting (e.g.

6. See also the excellent discussion of the definition of the shadow economy in Pedersen (2003, pp.13-19) and Kazemier (2005a) who use a similar one.

7. Compare also Feld and Schneider (2010) and Schneider (2011).

8. For a broader discussion of the definition issue see Thomas (1992), Schneider, Volkert and Caspar (2002), Schneider and Enste (2002, 2006), Kazemier (2005a, b) and Buehn, Karmann and Schneider (2009).

9. With this definition the problem of having classical crime activities included could be avoided, because neither the MIMIC procedure nor the currency demand approach captures these activities: e.g. drug dealing is independent of increasing taxes, especially as the included causal variables are not linked (or causal) to classical crime activities. See e.g. Thomas (1992), Kazemir (2005a, b) and Schneider (2005).

10 However, compare chapter 6, where it is shown, that shadow economy activities are partly captured in the official statistics in some countries. 
construction work in private homes) and its contribution to aggregate value added can be assessed rather positively.

Although the issue of the shadow economy has been investigated for a long time, the discussion regarding the "appropriate" methodology to assess its scope has not come to an end yet. ${ }^{11}$ There are three methods of assessment:

(1) Direct procedures at a micro level that aim at determining the size of the shadow economy at one particular point in time. An example is the survey method;

(2) Indirect procedures that make use of macroeconomic indicators in order to proxy the development of the shadow economy over time;

(3) Statistical models that use statistical tools to estimate the shadow economy as an "unobserved" variable.

Today in most cases the estimation of the shadow economy is based on a combination of the MIMIC procedure and on the currency demand method; or the use of only the currency demand method. ${ }^{12}$ The MIMIC procedure assumes that the shadow economy remains an unobserved phenomenon (latent variable) which can be estimated using quantitatively measurable causes of illicit employment, e.g. tax burden and regulation intensity, and indicators reflecting illicit activities, e.g. currency demand, official GDP and official working time. A disadvantage of the MIMIC procedure is the fact, that it produces only relative estimates of the size and the development of the shadow economy. Thus, the currency demand method ${ }^{13}$ is used to calibrate the relative into absolute estimates by using two or three absolute values of the absolute size of the shadow economy.

In addition, the size of the shadow economy is estimated by using survey methods (Feld and Larsen $(2005,2008,2009))$. In order to minimize the number of respondents dishonestly replying or totally declining answers to the sensitive questions, structured interviews are underta-

11. For the strengths and weaknesses of the various methods see Bhattacharyya (1999), Breusch (2005a, b), Dell'Anno and Schneider (2009), Dixon (1999), Feige (1989), Feld and Larsen (2005), Feld and Schneider (2010), Giles (1999a, b, c), Schneider (1986, 2001, 2003, 2005, 2006, 2011), Schneider and Enste (2000a, b, 2002, 2006), Tanzi (1999), Thomas (1992, 1999).

12. These methods are presented in detail in Schneider (1994a, b, c, 2005, 2011), Feld and Schneider (2010) and Schneider and Enste $(2000 \mathrm{~b}, 2002,2006)$. Furthermore, these studies discuss advantages and disadvantages of the MIMIC- and the money demand methods as well as other estimation methods for assessing the size of illicit employment; for a detailed discussion see also Feld and Larsen (2005).

13. This indirect approach is based on the assumption that cash is used to make transactions within the shadow economy. By using this method one econometrically estimates a currency demand function including independent variables like tax burden, regulation etc. which "drive" the shadow economy. This equation is used to make simulations of the amount of money that would be necessary to generate the official GDP. This amount is then compared with the actual money demand and the difference is treated as an indicator for the development of the shadow economy. On this basis the calculated difference is multiplied by the velocity of money of the official economy and one gets a value added figure for the shadow economy. See footnote 11 for references discussing critically this method. 
ken (usually face-to-face) in which the respondents are slowly getting accustomed to the main purpose of the survey. Like it is done by the contingent valuation method (CVM) in environmental economics (Kopp et al. 1997), a first part of the questionnaire aims at shaping respondents' perception as to the issue at hand. In a second part, questions about respondents' activities in the shadow economy are asked, and the third part contains the usual socio-demographic questions.

In addition to the studies by Merz and Wolff (1993), Feld and Larsen (2005, 2008, 2009), Haigner et al. (2011) and Enste and Schneider (2006) for Germany, the survey method has been applied in the Nordic countries and Great Britain (Isachsen and Strøm 1985, Pedersen 2003) as well as in the Netherlands (van Eck and Kazemier 1988, Kazemier 2006). While the questionnaires underlying these studies are broadly comparable in design, recent attempts by the European Union to provide survey results for all EU member states runs into difficulties regarding comparability (Renooy et al. 2004, European Commission 2007): the wording of the questionnaires becomes more and more cumbersome depending on the culture of different countries with respect to the underground economy.

These two sets of approaches are most broadly used in the literature. Although each has its drawbacks, and although biases in the estimates of the shadow economy almost certainly prevail, no better data are currently available. In tax compliance research, the most interesting data stem from actual tax audits by the US Internal Revenue Service (IRS). In the Taxpayer Compliance Measurement Program (TCMP), actual compliance behavior of taxpayers is observed and is used for empirical analysis (Andreoni, Erard and Feinstein 1998). The approach of the IRS is broader in a certain sense as tax evasion from all sources of income is considered, while the two methods discussed before aim at capturing the shadow economy or undeclared work and thus mainly measure tax evasion from labor income. Even the data obtained from the TCMP is biased however because the actually detected tax non-compliance could only be the tip of the iceberg. Although the perfect data on tax non-compliance does therefore not exist, the imperfect data in this area can still provide interesting insights also regarding the size, the development and the determinants of the shadow economy and of the shadow economy labor force.

\subsection{The Main Causes Determining the Shadow Economy}

A useful starting point for a theoretical discussion of tax non-compliance is the paper by Allingham and Sandmo (1972) on income tax evasion. While the shadow economy and tax eva- 
sion are not congruent, activities in the shadow economy in most cases imply the evasion of direct or indirect taxes, such that the factors affecting tax evasion will most certainly also affect the shadow economy. According to Allingham and Sandmo tax compliance depends on its expected costs and benefits. The benefits of tax non-compliance result from the individual marginal tax rate and the true individual income. In the case of the shadow economy the individual marginal tax rate is obtained by calculating the overall marginal tax burden from indirect and direct taxes including social security contributions. The individual income generated in the shadow economy is usually categorized as labor income and less probably as capital income. The expected costs of non-compliance derive from deterrence enacted by the state. Tax non-compliance thus depends on the state's auditing activities raising the probability of detection and the fines individuals face when they are caught. As individual morality also plays a role for compliance, additional costs could pertain beyond pure punishment by the tax administration in the form of psychic costs like shame or regret, but also additional pecuniary costs if, e.g., reputation loss results.

Kanniainen, Pääkönen and Schneider (2004) incorporate many of these insights in their model of the shadow economy by also considering labor supply decisions. They hypothesize that tax hikes unambiguously increase the shadow economy, while the effect of public goods financed by those taxes depends on the ability to access public goods. Morality is also included in this analysis. But the costs for individual non-compliers resulting from moral norms appear to be mainly captured by state punishment although self-esteem also plays a role.

A shortcoming of these analyses is the neglected endogeneity of tax morale and good governance. In contrast, Feld and Frey (2007) argue that tax compliance is the result of a complicated interaction between tax morale and deterrence measures. While it must be clear to taxpayers what the rules of the game are and as deterrence measures serve as signals for the tax morale a society wants to elicit (Posner 2000a, b), deterrence could also crowd out the intrinsic motivation to pay taxes. Moreover, tax morale is not only increased if taxpayers perceive the public goods received in exchange for their tax payments worth it. It also increases if political decisions for public activities are perceived to follow fair procedures or if the treatment of taxpayers by the tax authorities is perceived to be friendly and fair. Tax morale is thus not exogenously given, but is influenced by deterrence, the quality of state institutions and the constitutional differences among states.

Although this leaves me with a rich set of variables that might influence the size of the shadow economy, it is only the starting point. As labor supply decisions are involved, labor and 
product market regulations are additionally important. Recent theoretical approaches thus suggest following a differentiated policy to contain the shadow economy's expansion.

\subsubsection{Deterrence e $^{14}$}

Although the traditional economic theory of tax non-compliance derives unambiguous predictions as to their impact only for deterrence measures and despite the strong focus on deterrence in policies fighting the shadow economy, there is surprisingly little known about the effects of deterrence from empirical studies. In their survey on tax compliance, Andreoni, Erard and Feinstein (1998) report that deterrence matters for tax evasion, but that the reported effects are rather small. Blackwell (2009) finds strong deterrence effects of fines and audits in experimental tax evasion. Regarding the shadow economy, there is however little evidence.

This is due to the fact that data on the legal background and the frequency of audits are not available on an international basis. They would also be difficult to collect even for the OECD member countries. A recent study by Feld, Schmidt and Schneider (2007) demonstrates this for the case of Germany. The legal background is quite complicated differentiating fines and punishment according to the severity of the offense, to true income of the non-complier, but also regionally given different directives on sentences by the courts in different Länder. Moreover, the tax authorities at the state level do not reveal how intensively auditing is taking place. With the available data on fines and audits, Feld, Schmidt and Schneider (2007) conduct a time series analysis using the estimates of the shadow economy obtained by the MIMIC approach. According to their results, deterrence does not have a consistent effect on the German shadow economy. Conducting Granger causality tests, the direction of causation (in the sense of precedence) is ambiguous leaving room for an impact of the shadow economy on deterrence instead of deterrence on the shadow economy.

Feld and Larsen $(2005,2008,2009)$ follow a different approach by using individual survey data for Germany. First replicating Pedersen (2003), who reports a negative impact of the subjectively perceived risk of detection by state audits on the probability of working in the shadows for the year 2001, they then extend it by adding subjectively perceived measures of fines and punishment. Fines and punishment do not exert a negative influence on the shadow economy in any of the annual waves of surveys, nor in the pooled regressions for the years 2004-2007 (about 8000 observations overall). The subjectively perceived risk of detection has a robust and significant negative impact in individual years only for women. In the pooled sample for 2004-2007, which minimizes sampling problems, the probability of detection has a

\footnotetext{
${ }^{14}$ This part is taken from Feld and Schneider (2010, pp.115-116).
} 
significantly negative effect on the probability of working in the shadow economy also for men (keeping the one for women) and is robust across different specifications. ${ }^{15}$

Pedersen (2003) reports negative effects of the subjectively perceived risk of detection on the probability of conducting undeclared work in the shadows for men in Denmark in 2001 (marginally significant), for men in Norway in 1998/2002 (highly significant), ${ }^{16}$ men and women in Sweden in 1998 (highly significant in the first and marginally significant in the second case), and no significant effect for Great Britain in 2000. Moreover, van Eck and Kazemier (1988) report a significant negative of a high perceived probability of detection on participation in the hidden labor market for the Netherlands in 1982/1983. In none of these studies perceived fines and punishments are included as explanatory variables. The large scale survey study on Germany by Feld and Larsen $(2005,2009)$ thus appears to be the most careful analysis of deterrence effects on undeclared work up to date.

Overall, this is far from convincing evidence on the proper working of deterrence as it is always the combination of audits and fines that matters according to theoretical analysis, but also to pure plausibility arguments. The reasons for the unconvincing evidence of deterrence effects are discussed in the tax compliance literature by Andreoni, Erard and Feinstein (1998), Kirchler (2007) or Feld and Frey (2007). They range from interactions between tax morale and deterrence, thus the possibility that deterrence crowds out tax morale, to more mundane arguments like misperceptions of taxpayers. Likewise, these reasons could be important for the evidence on the deterrence effects on work in the shadow economy. As the latter mainly stems from survey studies, the insignificant findings for fines and punishment may also result from shortcomings in the survey design.

\subsubsection{Tax and Social Security Contribution Burdens}

In contrast to deterrence, almost all studies ascertain that the tax and social security contribution burdens are among the main causes for the existence of the shadow economy. ${ }^{17}$ Since taxes affect labor-leisure choices and stimulate labor supply in the shadow economy, the distortion of the overall tax burden is a major concern. The bigger the difference between the total labor cost in the official economy and after-tax earnings (from work), the greater is the incentive to reduce the tax wedge and work in the shadow economy. Since the tax wedge de-

15. An earlier study by Merz and Wolff (1993) does not analyze the impact of deterrence on undeclared work.

16. The earlier study by Isachsen and Strøm (1985) for Norway does also not properly analyze the impact of deterrence on undeclared work.

17. See Thomas (1992), Lippert and Walker (1997), Schneider (1994a, b, c, 1997, 1998a, b, 1999, 2000, 2003, 2005, 2009), Johnson, Kaufmann, and Zoido-Lobatón (1998a, b), Tanzi (1999), Giles (1999a), Mummert and Schneider (2001), Giles and Tedds (2002) and Dell'Anno (2003) as more recent ones. 
pends on the level and increase of the social security burden/payments and the overall tax burden, they are key features of the existence and the increase of the shadow economy.

\subsubsection{Intensity of Regulations}

Increased intensity of regulations, for example labor market regulations, trade barriers, and labor restrictions for immigrants. is another important factor which reduces the freedom (of choice) for individuals engaged in the official economy. Johnson, Kaufmann, and ZoidoLobatón (1998b) find significant empirical evidence of the influence of (labor) regulations on the shadow economy; and the impact is clearly described and theoretically derived in other studies, e.g. for Germany (Deregulierungskommission/ Deregulation Commission 1991). ${ }^{18}$ Regulations lead to a substantial increase in labor costs in the official economy. But since most of these costs can be shifted to employees, regulations provide for another incentive to work in the shadow economy where they can be avoided. Johnson, Kaufmann, and Shleifer (1997) report empirical evidence supporting their model which predicts that countries with higher general regulation of their economies tend to have a higher share of the unofficial economy in total GDP. They conclude that it is the enforcement of regulation which is the key factor for the burden levied on firms and individuals, and not the overall extent of regulation mostly not enforced - which drives firms into the shadow economy. Friedman, Johnson, Kaufmann and Zoido-Lobaton (2000) arrive at a similar conclusion. In their study every available measure of regulation is significantly correlated with the share of the unofficial economy and the estimated sign of the relationship is unambiguous: more regulation is correlated with a larger shadow economy.

\subsubsection{Public Sector Services}

An increase of the shadow economy can lead to reduced state revenues which in turn reduce the quality and quantity of publicly provided goods and services. Ultimately, this can lead to an increase in the tax rates for firms and individuals in the official sector, quite often combined with a deterioration in the quality of the public goods (such as the public infrastructure) and of the administration, with the consequence of even stronger incentives to participate in the shadow economy. Johnson, Kaufmann, and Zoido-Lobatón (1998a, b) present a simple model of this relationship. According to their findings smaller shadow economies occur in countries with higher tax revenues achieved by lower tax rates, fewer laws and regulations and less bribery facing enterprises. Countries with a better rule of law, which is financed by tax revenues, also have smaller shadow economies. Transition countries have higher levels of

18. The importance of regulation on the official and unofficial (shadow) economy is more recently investigated by Loayza, Oviedo and Servén (2005a, b). Kucera and Roncolato (2008) extensively analyze the impact of labor market regulation on the shadow economy. 
regulation leading to a significantly higher incidence of bribery, higher effective taxes on official activities and a large discretionary framework of regulations and consequently a higher shadow economy. Their overall conclusion is that "wealthier countries of the OECD, as well as some in Eastern Europe, find themselves in the 'good equilibrium' of relatively low tax and regulatory burden, sizeable revenue mobilization, good rule of law and corruption control, and a [relatively] small unofficial economy. By contrast, a number of countries in Latin American and the former Soviet Union exhibit characteristics consistent with a 'bad equilibrium': tax and regulatory discretion and burden on the firm is high, the rule of law is weak, and there is a high incidence of bribery and a relatively high share of activities in the unofficial economy.” (Johnson, Kaufmann and Zoido-Lobatón 1998a, p. I).

\subsubsection{Other Public Institutions}

Recently, various authors ${ }^{19}$ consider quality of public institutions as another key factor of the development of the informal sector. They argue that the efficient and discretionary application of tax systems and regulations by government may play a crucial role in the decision of conducting undeclared work, even more important than the actual burden of taxes and regulations. In particular, corruption of bureaucracy and government officials seems to be associated with larger unofficial activity, while a good rule of law by securing property rights and contract enforceability, increases the benefits of being formal.

Hence, it is important to analyze theoretically and empirically the effect of political institutions like the federal political system on the shadow economy. If the development of the informal sector is considered as a consequence of the failure of political institutions in promoting an efficient market economy, since entrepreneurs go underground when there is an inefficient public goods provision, then the effect of institutions of the individual's incentive to operate unofficially can be assessed. In a federal system, competition among jurisdictions and the mobility of individuals act as constraints on politicians because "choices" will be induced that provide incentives to adopt policies which are closer to a majority of voters' preferences. Frequently, the efficient policies are characterized by a certain level of taxation, mostly spent in productive public services. In fact, the production in the formal sector benefits from a higher provision of the productive public services and is negatively affected by taxation, while the shadow economy reacts in the opposite way. As fiscal policy gets closer to a majority of voters' preferences in federal systems, the size of the informal sector goes down. This leads to the hypothesis that the size of the shadow economy should be lower in a federal system than

${ }^{19}$ See e.g. Johnson et al. (1998a, b), Friedman et al. (2000), Dreher and Schneider (2009), Dreher, Kotsogiannis and Macorriston (2007, 2009), as well as Teobaldelli (2011), Teobaldelli and Schneider (2012), Schneider (2010) and Buehn and Schneider (2010). 
in a unitary state, ceteris paribus. Moreover Teobaldelli and Schneider (2012) found out that direct democracy has a quantitative and statistically significant influence on the size of the shadow economy. The more direct democratic elements a country has, the lower the shadow economy, ceteris paribus.

\subsubsection{Tax Morale}

In addition to the incentives effects discussed before, the efficiency of the public sector has an indirect effect on the size of the shadow economy because it affects tax morale. As Feld and Frey (2007) argue, tax compliance is driven by a psychological tax contract that entails rights and obligations from taxpayers and citizens on the one hand, but also from the state and its tax authorities on the other hand. Taxpayers are more heavily inclined to pay their taxes honestly if they get valuable public services in exchange. However, taxpayers are honest even in cases when the benefit principle of taxation does not hold, i.e. for redistributive policies, if the political decisions underlying such policies follow fair procedures. Finally, the treatment of taxpayers by the tax authority plays a role. If taxpayers are treated like partners in a (tax) contract instead of subordinates in a hierarchical relationship, taxpayers will stick to their obligations of the psychological tax contract more easily. In addition to the empirical evidence on these arguments reported by Feld and Frey (2007), and by Kirchler (2007) present a comprehensive discussion of the influence of such factors on tax compliance.

Regarding the impact of tax morale on the shadow economy, there is scarce and only recent evidence. Using data on the shadow economy obtained by the MIMIC approach, Torgler and Schneider (2009) report the most convincing evidence for a negative effect of tax morale. They particularly address causality issues and establish a causal negative relation from tax morale to the size of the shadow economy. This effect is also robust to the inclusion of additional explanatory factors and specifications. These findings are also in line with earlier preliminary evidence by Körner et al. (2006). Using survey data, Feld and Larsen $(2005,2009)$ likewise report a robust negative effect of tax morale in particular and social norms in general on the probability of respondents to conduct undeclared work. Interestingly, the estimated effects of social norms are quantitatively more important than the estimated deterrence effects. Van Eck and Kazemier (1988) also report a marginally significant effect of tax morale on the participation in the hidden labor market.

\subsubsection{Summary of the Main Causes of the Shadow Economy}

In Table 2.2 an overview of a number of empirical studies summarizes the various factors influencing the shadow economy. The overview is based on the studies in which the size of the shadow economy is measured by the MIMIC or currency demand approach. As there is no 
evidence on deterrence using these approaches - at least with respect to the broad panel data base on which this table draws - the most central policy variable does not show up. This is an obvious shortcoming of the studies, but one that cannot be coped with easily due to the lack of internationally comparable deterrence data. In Table 2.2 two columns are presented, showing the various factors influencing the shadow economy with and without the independent variable, "tax morale". This table clearly demonstrates that the increase of tax and social security contribution burdens is by far most important single contributor to the increase of the shadow economy. This factor does explain some $35-38 \%$ or $45-52 \%$ of the variance of the shadow economy with and without including the variable "tax morale". The variable tax morale accounts for some $22-25 \%$ of the variance of the shadow economy, ${ }^{20}$ there is a third factor, "quality of state institutions", accounting for $10-12 \%$ and a forth factor, "intensity of state regulation“ (mostly for the labor market) for 7-9\%. In general Table 2.2 shows that the independent variables tax and social security burden, followed by variables tax morale and intensity of state regulations are the three major driving forces of the shadow economy.

Table 2.2: Main Causes of the Increase of the Shadow Economy

\begin{tabular}{|ll|c|c|}
\hline \multirow{2}{*}{ Factors influencing the shadow economy } & Influence on the shadow economy (in \%) \\
\cline { 3 - 4 } & (a) & (b) \\
\hline (1) & $\begin{array}{l}\text { Increase of the Tax and Social Security Con- } \\
\text { tribution Burdens }\end{array}$ & $35-38$ & $45-52$ \\
\hline (2) & Quality of State Institutions & $10-12$ & $12-17$ \\
\hline (3) $\quad$ Transfers & $5-7$ & $7-9$ \\
\hline (4) $\quad$ Specific Labor Market Regulations & $7-9$ & $7-9$ \\
\hline (5) $\quad$ Public Sector Services & $5-7$ & $7-9$ \\
\hline (6) $\quad$ Tax Morale & $22-25$ & - \\
\hline $\begin{array}{l}\text { Influence of all Factors } \\
\text { (a) Average values of 12 studies. } \\
\text { (b) Average values of empirical results of 22 studies. } \\
\text { Source: Schneider (2009) }\end{array}$ & $84-98$ & $78-96$ \\
\hline
\end{tabular}

20. The importance of this variable with respect to theory and empirical relevance is also shown in Frey (1997), Feld and Frey (2002a, 2002b, 2007) and Torgler and Schneider (2009). 


\section{ESTIMATION AND SIZE OF THE SHADOW ECONOMIES IN HIGHLY DEVELOPED OECD COUNTRIES}

\subsection{Econometric Estimation}

Following the theoretical considerations in section 2, I develop seven hypotheses below (all ceteris paribus), which will be empirically tested subsequently using the MIMIC approach:

1. An increase in direct and indirect taxation increases the shadow economy.

2. An increase in social security contributions increases the shadow economy.

3. The more the country is regulated, the greater the incentives are to work in the shadow economy.

4. The lower the quality of state institutions, the higher the incentives to work in the shadow economy.

5. The lower tax morale, the higher the incentives to work in the shadow economy.

6. The higher unemployment, the more people engage in shadow economy activities.

7. The lower GDP per capita in a country, the higher is the incentive to work in the shadow economy.

As the sample consists of 21 highly developed OECD countries between 1990 and 2007

(pooled cross section time series data), the effect of deterrence cannot be empirically tested. As the size of fines and punishment and the probability of detection are only available for one or two countries across time. They are not considered here. The following estimation results thus rather correspond to the factors reported in Table 2.2 which are gained from an overview of existing studies. 


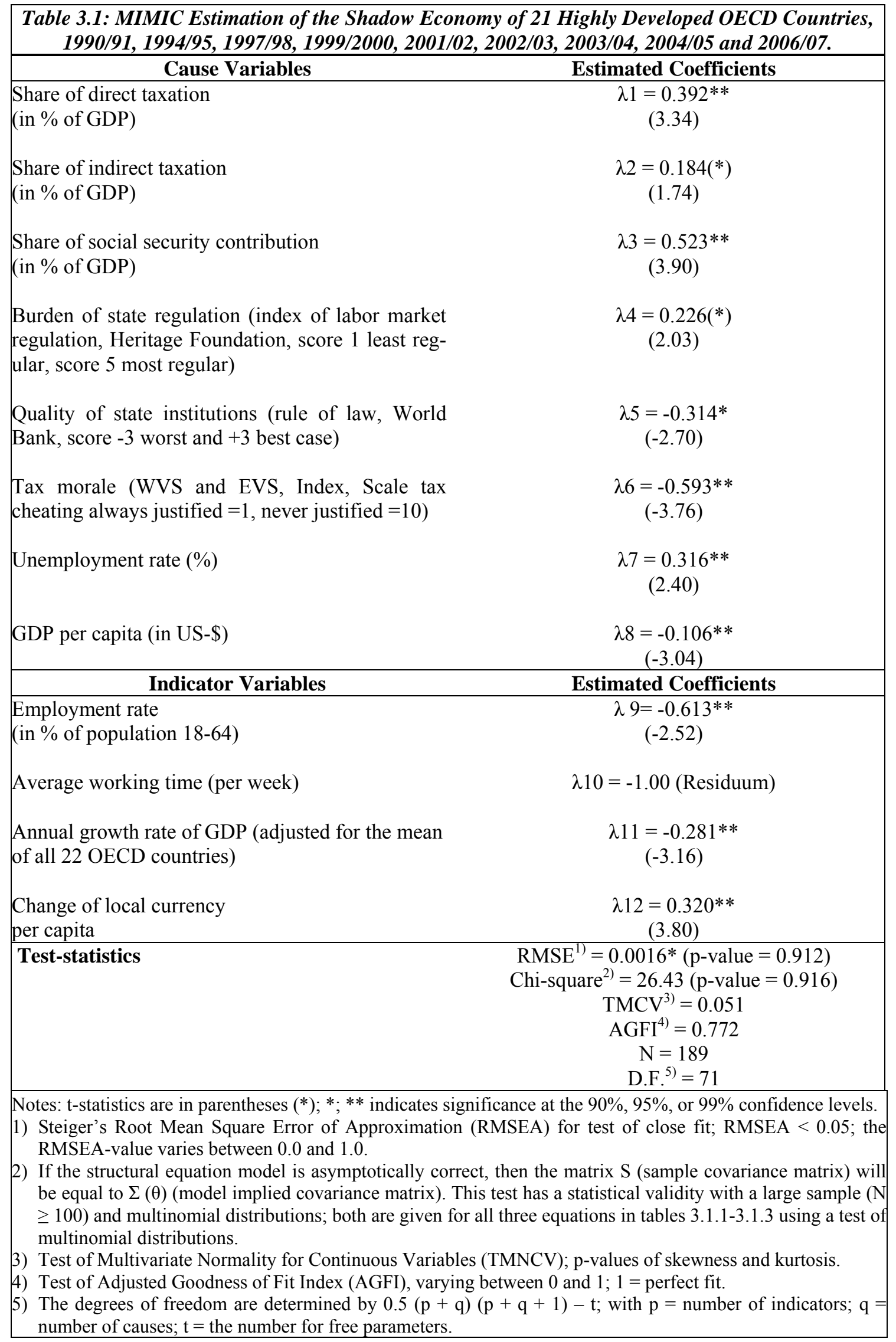


In Table 3.1 the econometric results using the MIMIC approach (latent estimation approach) are presented for these 21 OECD-countries for which I have nine data points of the years 1990/91, 1994/95, 1997/98, 1999/2000, 2001/02, 2002/03, 2003/04, 2004/05 and 2006/07.

Besides the usual cause variables like direct and indirect taxation, social security contributions and state regulation I have added two further causal factors, i.e. tax morale and the quality of state institutions. In addition to the employment rate, the annual growth rate of GDP and the change of currency per capita, I use the average working time (per week) as an additional indicator variable. ${ }^{21}$ The estimated coefficients of all eight cause variables are statistically significant and have the theoretically expected signs. The tax and social security burden variables are quantitatively the most important ones, followed by the tax morale variable which has the single biggest influence. Also the independent variable quality of state institutions is statistically significant and quite important to determine whether one is engaged in shadow economy activities or not. The development of the official economy measured by unemployment and GDP per capita has a quantitatively important influence on the shadow economy. Turning to the indicator variables they all have a statistically significant influence and the estimated coefficients have the theoretically expected signs. The quantitatively most important independent variables are the employment rate and the change of currency per capita. ${ }^{22}$ Summarizing, the econometric results demonstrate that in these OECD countries the social security contributions and the share of direct taxation have the biggest influence, followed by tax morale and the quality of state institutions ${ }^{23}$.

\subsection{The Development and Size of the Shadow Economy in Germany}

Various estimates of the German shadow economy (measured in percentage of official GDP) are shown in table 3.2 (see also Feld et.al. 2007). The oldest estimate uses the survey method of the Institute for Demoscopy (IfD) in Allensbach, Germany, and shows that the shadow economy was $3.6 \%$ of official GDP in 1974. In a much later study, Feld and Larsen (2005, 2008) undertook an extensive research project using the survey method to estimate shadow economic activities in the years 2001 to $2006 .{ }^{24}$ Using the officially paid wage rate, they con-

21. Using this indicator variable the problem might arise that this variable is influenced by state regulation, so that it is not exogenous; hence the estimation may be biased, this problem applies for almost all causal variables!

22. The variable currency per capita or annual change of currency per capita is heavily influenced by banking innovations or payment; hence this variable is pretty unstable with respect to the length of the estimation period. Similar problems are already mentioned by Giles (1999a) and Giles and Tedds (2002).

23. Compare also Schneider, Buehn and Montenegro (2010), and Feld and Schneider (2010).

24. In my paper there is no extensive discussion about the various methods to estimate the size and development of the shadow economy; I do also not discuss the strength and weaknesses of each method. See Schneider and Enste (2000), Schneider (2005, 2011), Feld and Larsen (2005, 2008, 2009), Pedersen (2003), and Giles (1999a, b, c). 
cluded that these activities reached $4.1 \%$ in $2001,3.1 \%$ in $2004,3.6 \%$ in 2005 and $2.5 \%$ in $2006 .{ }^{25}$ Using the (much lower) shadow economy wage rate these estimates shrink however to $1.3 \%$ in 2001 and $1.0 \%$ in 2004 , respectively. If I consider the discrepancy method, for which I have estimates from 1970 to 1980 , the German shadow economy is much larger: using the discrepancy between expenditure and income, I get approximately $11 \%$ for the 1970 s, and using the discrepancy between official and actual employment, roughly $30 \%$. The physical input methods from which estimates for the 1980s are available, "deliver" values of around $15 \%$ for the second half of that decade. The (monetary) transaction approach developed by Feige (1989) places the shadow economy at 30\% between 1980 and 1985 . Yet another monetary approach, the currency demand approach - the first person to undertake an estimation for Germany was Kirchgässner $(1983,1984)$ - provides values of 3.1\% (1970) and 10.1\% (1980). Kirchgässner's values are quite similar to the ones obtained by Schneider and Enste (2000, 2002), who also used a currency demand approach to value the size of the shadow economy at $4.5 \%$ in 1970 and $14.7 \%$ in 2000. Finally, if I look at latent MIMIC estimation procedures, the first ones being conducted by Frey and Weck-Hannemann (1984), and later, Schneider and others followed for Germany, again, the estimations for the 1970s are quite similar. Furthermore, Schneider's estimates using a MIMIC approach (Schneider 2005, 2009) are close to those of the currency demand approach.

Thus, one can see that different estimation procedures produce different results. It is safe to say that the figures produced by the transaction and the discrepancy approaches are rather unrealistically large: the size of the shadow economy at almost one third of official GDP in the mid-1980s is most likely an overestimate. The figures obtained using the currency demand and hidden variable (latent) approaches, on the other hand, are relatively close together and much lower than those produced by other methods (i.e. the discrepancy or transaction approaches). This similarity is not surprising given the fact that the estimates of the shadow economy using the latent (MIMIC) approach were measured by taking point estimates from the currency demand approach. The estimates from the MIMIC approach can be regarded as the upper bound of the size of the shadow economy. For the reasons outlined in Section 2, the estimates obtained from the survey approach provide for its lower bound. It should be noted that the "true" size of the shadow economy does not necessarily lie between both bounds, nor

25. Feld and Larsen (2008) argue, that due to the extraordinarily low rate of participation based on a relatively small sample, the results for 2006 must be interpreted with extra great care. The results for 2006 should be regarded as tentative and, at the most, as an indication that black activities do not appear to have increased from 2005 to 2006 . Additionally it should be noted that they measure "only" black household activities and not the ones of firms. 
is it precluded that it is closer to the upper than the lower bound. But both benchmarks help us to understand the phenomenon better.

\subsection{Size and Development of the Shadow Economy in 21 OECD Countries}

In order to calculate the size and development of the shadow economies of the 21 OECD countries, I have to overcome the disadvantage of the MIMIC approach, which is, that only relative sizes of the shadow economy are obtained such that another approach to calculate absolute figures must be used. For the calculation of the absolute sizes of the shadow economies from these MIMIC estimation results, I take the already available estimates from the currency demand approach for Austria, Germany, Italy and the United States (from studies of Dell'Anno and Schneider 2003, Bajada and Schneider 2005, and Schneider and Enste 2002). As I have values of the shadow economy (in \% of GDP) for various years for the above mentioned countries, we can use them in a benchmark procedure to transform the index of the shadow economy from the MIMIC estimations into cardinal values. ${ }^{26}$

Table 3.3 presents the findings for 21 OECD countries until 2007. They clearly reveal that since the end of 90's the size of the shadow economy in most OECD countries continued to decrease. The unweighted average for all countries in 1999/2000 was $16.8 \%$ and dropped to $13.9 \%$ in 2007 . This means, that since $1997 / 98$ - the year in which the shadow economy was the biggest in most OECD countries, it has continuously shrunk. Only in Germany, Austria and Switzerland the growing trend lasted longer and was reversed two or three years ago. The reduction of the share of the shadow economy from GDP between 1997/98 and 2007 is most pronounced in Italy $(-5.0 \%)$ and in Sweden (-4.0). The German shadow economy ranges in the middle of the ranking, whereas Austria and Switzerland are located at the lower end. With $20 \%$ to $26 \%$, South European countries exhibit the biggest shadow economies measured as a share from official GDP. They are followed by Scandinavian countries whose shadow economies' shares in GDP range between 15 and 16\%. One reason for the differences in the size of the shadow economy between these OECD countries includes, among others, that for example there are fewer regulations in the OECD country USA compared to the OECD country Germany where everything is forbidden, what is not explicitly allowed. The individual's freedom is limited in many areas by far-reaching state interventions. Another reason is the large differences in the direct and indirect tax burden with the lowest in the U.S. and Switzerland in this sample.

26. This procedure is described in great detail in the paper Dell'Anno and Schneider $(2004,2009)$. 


\subsection{Development and Size of the Shadow Economies all over the world ${ }^{27}$}

Figure 3.1 shows the average size of the shadow economy of 162 countries over 1999-2007. ${ }^{28}$ In tables 3.4 und 3.5 the average informality (unweighted and weighted) in different regions is shown using the regions defined by the World Bank. The World Bank distinguishes 8 world regions which are East Asia and Pacific, Europe and Central Asia, Latin America and the Caribbean, Middle East and North Africa, High Income OECD, Other High Income, South Asia, and Sub-Saharan Africa. If we consider first table 3.4 where the average informality (unweighted) is shown, we see that Latin America and the Caribbean have the highest value of the shadow economies of $41.1 \%$, followed by Sub-Saharan Africa of $40.2 \%$ and then followed by Europe and Central Asia of 38.9\%. The lowest have the High Income OECD countries with $17.1 \%$. If we consider the average informality of the shadow economies of these regions weighted by total GDP in 2005, Sub-Saharan Africa has the highest with $37.6 \%$, followed by Europe and Central Asia with 36.4\% and Latin America and the Caribbean with $34.7 \%$. The lowest again has the High Income OECD with $13.4 \%$. If one considers the world mean weighted and unweighted, one sees that if one uses the unweighted measures the mean is $33.0 \%$ over the periods $1999-2007$. If we consider the world with weighted informality measures the shadow economy takes "only" a value of $17.1 \%$ over the period 1999-2007. Weighting the values makes a considerable difference.

One general result of the size and development of the shadow economies world wide is that there is an overall reduction in the size. In figure 3.2 the size and development of the shadow economy of various countries groups (weighted averages by the official GDP of 2005) over 1999, 2003 and 2007 are shown. One clearly realizes that for all countries groups (25 OECD countries, 116 developing counties, 25 transition countries) I observe a decrease in the size of the shadow economy. The average size of the shadow economies of the 162 countries was $34.0 \%$ of official GDP (unweighted measure!) in 1999 and decreased to $31.2 \%$ of official GDP in 2007 (compare table A1 in the appendix). This is a decrease of almost 3.0 percentage points over 9 years. Growth of the official economy with reduced (increased) unemployment (employment) seems to be the most efficient mean to reduce the shadow economy.

27. This part and the figures are taken from Schneider, Buehn and Montenegro (2010)

28. In the appendix a list of these 162 countries in alphabetical order is shown. 
Table 3.2: The Size of the Shadow Economy in Germany According to Different Methods (in Percentage of Official GDP)

\begin{tabular}{|c|c|c|c|c|c|c|c|c|c|}
\hline \multirow[t]{2}{*}{ Method } & \multicolumn{8}{|c|}{ Shadow economy in Germany (in percentage of official GDP) in: } & \multirow[t]{2}{*}{ Source } \\
\hline & 1970 & 1975 & 1980 & 1985 & 1990 & 1995 & 2000 & 2005 & \\
\hline Survey & - & $\begin{array}{c}3.6^{1)} \\
-\end{array}$ & - & $\begin{array}{ll}- \\
-\end{array}$ & - & - & $\overline{-}^{2)}$ & $\overline{-}^{2}$ & $\begin{array}{l}\text { IfD Allensbach }(1975) \\
\text { Feld and Larsen }(2005,2008)\end{array}$ \\
\hline $\begin{array}{l}\text { Discrepancy between expenditure and } \\
\text { income }\end{array}$ & 11.0 & 10.2 & 13.4 & - & - & - & - & - & Lippert and Walker (1997) \\
\hline $\begin{array}{l}\text { Discrepancy between official and ac- } \\
\text { tual employment }\end{array}$ & 23.0 & 38.5 & 34.0 & - & - & - & - & - & Langfeldt $(1984 a, b)$ \\
\hline Physical input method & - & - & - & 14.5 & 14.6 & - & - & - & Feld and Larsen (2005) \\
\hline Transactions approach & 17.2 & 22.3 & 29.3 & 31.4 & - & - & - & - & Langfeldt $(1984 a, b)$ \\
\hline Currency demand approach & $\begin{array}{c}3.1 \\
12.1 \\
4.5\end{array}$ & $\begin{array}{c}6.0 \\
11.8 \\
7.8\end{array}$ & $\begin{array}{c}10.3 \\
12.6 \\
9.2\end{array}$ & $\begin{array}{c}- \\
- \\
11.3\end{array}$ & $\begin{array}{c}- \\
- \\
11.8\end{array}$ & $\begin{array}{c}- \\
- \\
12.5\end{array}$ & $\begin{array}{c}- \\
- \\
14.7\end{array}$ & $\begin{array}{l}- \\
- \\
-\end{array}$ & $\begin{array}{l}\text { Kirchgässner (1983) } \\
\text { Langfeldt (1984a, b) } \\
\text { Schneider and Enste (2000) }\end{array}$ \\
\hline Latent (MIMIC) approach & $\begin{array}{c}5.8 \\
-\end{array}$ & $\begin{array}{c}6.1 \\
-\end{array}$ & $\begin{array}{l}8.2 \\
9.4\end{array}$ & - & $\overline{-}$ & $\overline{-}$ & $\overline{-}$ & $\begin{array}{l}- \\
-\end{array}$ & $\begin{array}{l}\text { Frey and Weck (1984) } \\
\text { Pickhardt and Sarda Pons } \\
(2006)\end{array}$ \\
\hline & 4.2 & 5.8 & 10.8 & 11.2 & 12.2 & 13.9 & 16.0 & 15.4 & Schneider $(2005,2007)$ \\
\hline Soft modeling & - & $8.3^{4)}$ & - & - & - & - & - & - & Weck-Hannemann (1983) \\
\hline
\end{tabular}




\begin{tabular}{|c|c|c|c|c|c|c|c|c|c|c|}
\hline \multicolumn{11}{|c|}{$\begin{array}{c}\text { Table 3.3: The Size of the Shadow Economy (in \% of Official GDP) in } 21 \text { OECD Countries between } 1989 / 90 \text { and } 2007 \\
\text { Estimated Using and MIMIC Method and the Currency Demand Approach to Calibrate the MIMIC values }\end{array}$} \\
\hline & \multicolumn{10}{|c|}{ Shadow Economy (in \% of official GDP) } \\
\hline OECD-countries & Average 1989/90 & Average 1994/95 & Average 1997/98 & Average 1999/00 & Average 2001/02 & 2003 & 2004 & 2005 & 2006 & 2007 \\
\hline 1. Australia & 10.1 & 13.5 & 14.0 & 14.3 & 14.1 & 13.7 & 13.2 & 12.6 & 11.4 & 10.7 \\
\hline 2. Belgium & 19.3 & 21.5 & 22.5 & 22.2 & 22.0 & 21.4 & 20.7 & 20.1 & 19.2 & 18.3 \\
\hline 3. Canada & 12.8 & 14.8 & 16.2 & 16.0 & 15.8 & 15.3 & 15.1 & 14.3 & 13.2 & 12.6 \\
\hline 4. Denmark & 10.8 & 17.8 & 18.3 & 18.0 & 17.9 & 17.4 & 17.1 & 16.5 & 15.4 & 14.8 \\
\hline 5. Germany & 11.8 & 13.5 & 14.9 & 16.0 & 16.3 & 17.1 & 16.1 & 15.4 & 14.9 & 14.6 \\
\hline 6. Finland & 13.4 & 18.2 & 18.9 & 18.1 & 18.0 & 17.6 & 17.2 & 16.6 & 15.3 & 14.5 \\
\hline 7. France & 9.0 & 14.5 & 14.9 & 15.2 & 15.0 & 14.7 & 14.3 & 13.8 & 12.4 & 11.8 \\
\hline 8. Greece & 22.6 & 28.6 & 29.0 & 28.7 & 28.5 & 28.2 & 28.1 & 27.6 & 26.2 & 25.1 \\
\hline 9. Great Britain & 9.6 & 12.5 & 13.0 & 12.7 & 12.5 & 12.2 & 12.3 & 12.0 & 11.1 & 10.6 \\
\hline 10. Ireland & 11.0 & 15.4 & 16.2 & 15.9 & 15.7 & 15.4 & 15.2 & 14.8 & 13.4 & 12.7 \\
\hline 11. Italy & 22.8 & 26.0 & 27.3 & 27.1 & 27.0 & 26.1 & 25.2 & 24.4 & 23.2 & 22.3 \\
\hline 12. Japan & 8.8 & 10.6 & 11.1 & 11.2 & 11.1 & 11.0 & 10.7 & 10.3 & 9.4 & 9.0 \\
\hline 13. Netherlands & 11.9 & 13.7 & 13.5 & 13.1 & 13.0 & 12.7 & 12.5 & 12.0 & 10.9 & 10.1 \\
\hline 14. New Zealand & 9.2 & 11.3 & 11.9 & 12.8 & 12.6 & 12.3 & 12.2 & 11.7 & 10.4 & 9.8 \\
\hline 15. Norway & 14.8 & 18.2 & 19.6 & 19.1 & 19.0 & 18.6 & 18.2 & 17.6 & 16.1 & 15.4 \\
\hline 16. Austria & 6.9 & 8.6 & 9.0 & 9.8 & 10.6 & 10.8 & 11.0 & 10.3 & 9.7 & 9.4 \\
\hline 17. Portugal & 15.9 & 22.1 & 23.1 & 22.7 & 22.5 & 22.2 & 21.7 & 21.2 & 20.1 & 19.2 \\
\hline 18. Sweden & 15.8 & 19.5 & 19.9 & 19.2 & 19.1 & 18.6 & 18.1 & 17.5 & 16.2 & 15.6 \\
\hline 19. Switzerland & 6.7 & 7.8 & 8.1 & 8.6 & 9.4 & 9.5 & 9.4 & 9.0 & 8.5 & 8.2 \\
\hline 20. Spain & 16.1 & 22.4 & 23.1 & 22.7 & 22.5 & 22.2 & 21.9 & 21.3 & 20.2 & 19.3 \\
\hline 21. USA & 6.7 & 8.8 & 8.9 & 8.7 & 8.7 & 8.5 & 8.4 & 8.2 & 7.5 & 7.2 \\
\hline $\begin{array}{l}\text { Unweighted average for } \\
21 \text { OECD countries }\end{array}$ & 12.7 & 16.2 & 16.8 & 16.8 & 16.7 & 16.5 & 16.1 & 15.6 & 14.5 & 13.9 \\
\hline
\end{tabular}




\begin{tabular}{|c|c|c|c|c|c|c|}
\hline \multicolumn{7}{|c|}{ Table 3.4:Average Informality (Unweighted) by World Bank's Regions } \\
\hline & Region & mean & median & $\min$ & $\max$ & sd \\
\hline EAP & East Asia and Pacific & 32.3 & 32.4 & 12.7 & 50.6 & 13.3 \\
\hline ECA & Europe and Central Asia & 38.9 & 39.0 & 18.1 & 65.8 & 10.9 \\
\hline LAC & Latin America and the Caribbean & 41.1 & 38.8 & 19.3 & 66.1 & 12.3 \\
\hline MENA & Middle East and North Africa & 28.0 & 32.5 & 18.3 & 37.2 & 7.8 \\
\hline OECD & High Income OECD & 17.1 & 15.8 & 8.5 & 28.0 & 6.1 \\
\hline OHIE & Other High Income & 23.0 & 25.0 & 12.4 & 33.4 & 7.0 \\
\hline SAS & South Asia & 33.2 & 35.3 & 22.2 & 43.9 & 7.0 \\
\hline SSA & Sub-Saharan Africa & 40.2 & 40.6 & 18.4 & 61.8 & 8.3 \\
\hline World & & 33.0 & 33.5 & 8.5 & 66.1 & 12.8 \\
\hline
\end{tabular}

Source: Schneider, Buehn and Montenegro (2010) 
Table 3.5: Average Informality (Weighted) by Total GDP in 2005

\begin{tabular}{|c|c|c|c|c|c|c|}
\hline & Region & Mean & median & $\min$ & $\max$ & sd \\
\hline EAP & East Asia and Pacific & 17.5 & 12.7 & 12.7 & 50.6 & 10.6 \\
\hline ECA & Europe and Central Asia & 36.4 & 32.6 & 18.1 & 65.8 & 8.4 \\
\hline LAC & Latin America and the Caribbean & 34.7 & 33.8 & 19.3 & 66.1 & 7.9 \\
\hline MENA & Middle East and North Africa & 27.3 & 32.5 & 18.3 & 37.2 & 7.7 \\
\hline OECD & High Income OECD & 13.4 & 11.0 & 8.5 & 28.0 & 5.7 \\
\hline OHIE & Other High Income & 20.8 & 19.4 & 12.4 & 33.4 & 4.9 \\
\hline SAS & South Asia & 25.1 & 22.2 & 22.2 & 43.9 & 5.9 \\
\hline SSA & Sub-Saharan Africa & 37.6 & 33.2 & 18.4 & 61.8 & 11.7 \\
\hline World & & 17.1 & 13.2 & 8.5 & 66.1 & 9.9 \\
\hline
\end{tabular}

Source: Schneider, Buehn and Montenegro (2010) 
Figure 3.1: Average Size of the Shadow Economy of 162 Countries over 1999-2007

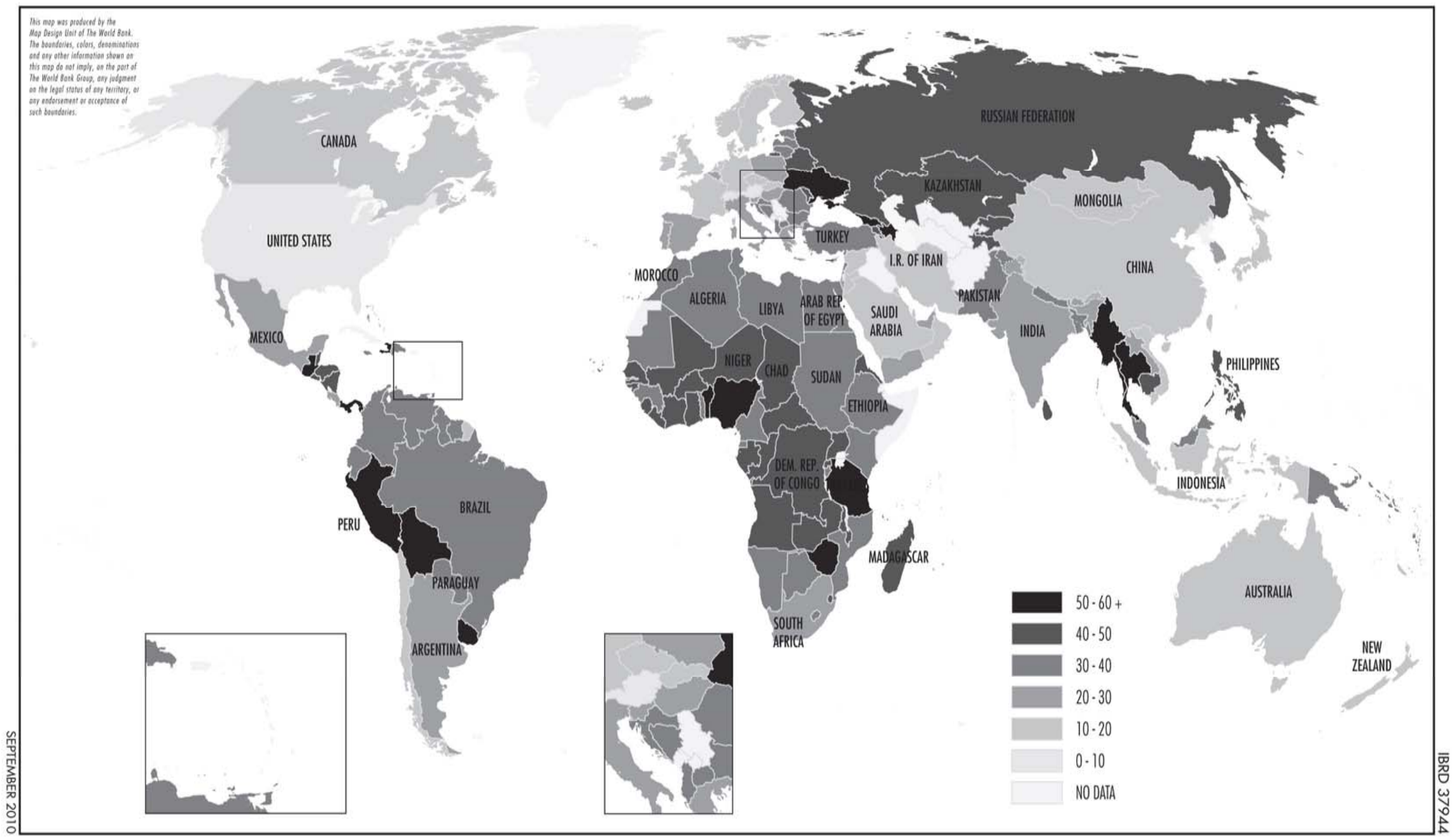

Source: Schneider, Buehn and Montenegro (2010) 
Figure 3.2: Size and Development of the Shadow Economy of Various Countries Groups (Weighted Averages (!); in percent of official total GDP of the respective Country Group)

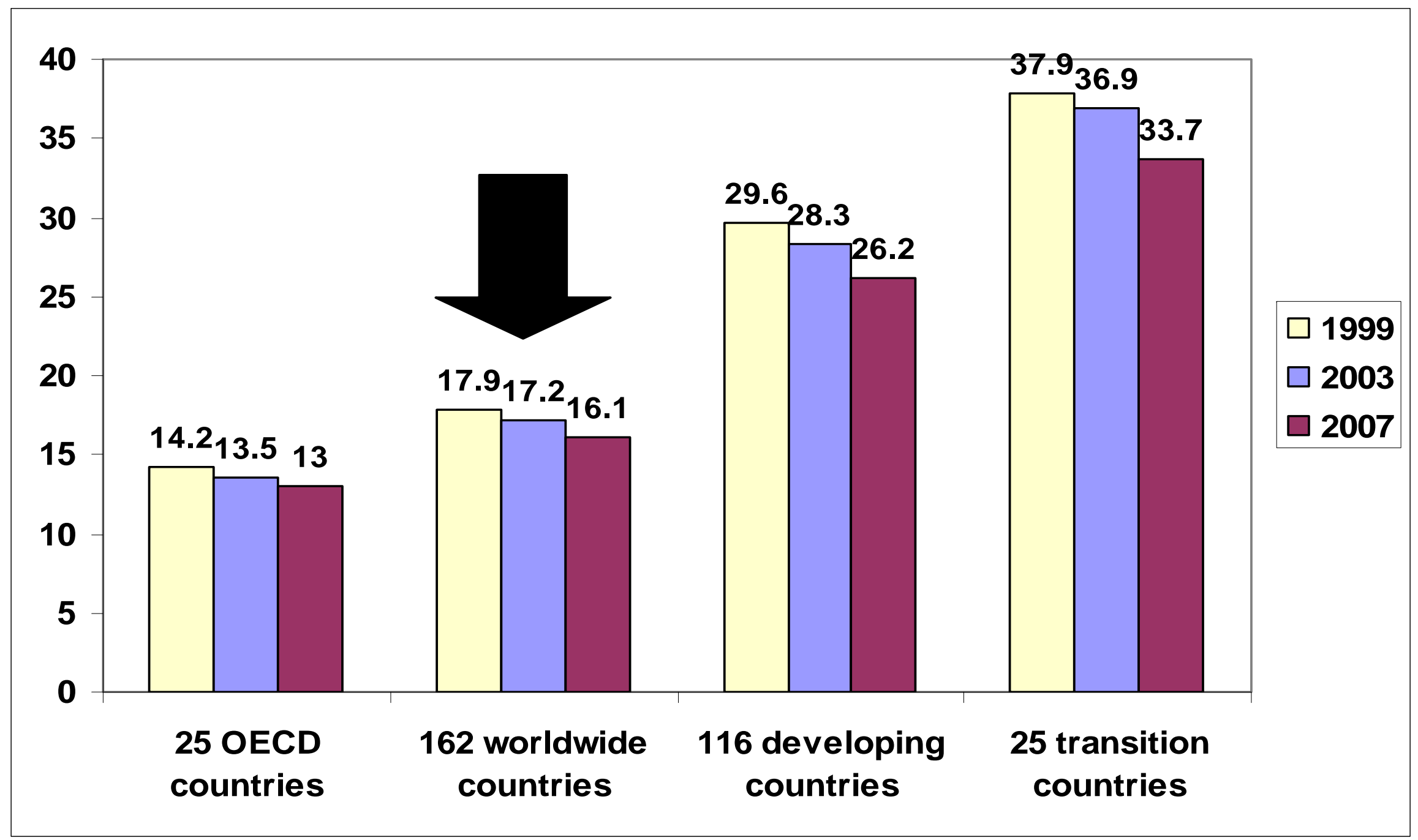

Source: Schneider, Buehn and Montenegro (2010) 


\section{SHADOW ECONOMY LABOR FORCE AND LABOR MARKET}

\subsection{Shadow Economy Labor Market}

Having examined the size, rise and fall of the shadow economy in terms of value added over time, the analysis now focuses on the "shadow labor market", as within the official labor market there is a particularly tight relationship and "social network" between people who are active in the shadow economy. ${ }^{29}$ Moreover, by definition every activity in the shadow economy involves a "shadow labor market" to some extent: ${ }^{30}$ Hence, the "shadow labor market" includes all cases, where the employees or the employers, or both, occupy a "shadow economy position“.

Why do people work in the shadow economy? In the official labor market, the costs firms (and individuals) have to pay when "officially" hiring someone are tremendously increased by the burden of tax and social contributions on wages, as well as by the legal administrative regulation to control economic activity. In various OECD countries, these costs are greater than the wage effectively earned by the worker - providing a strong incentive to work in the shadow economy.

More detailed theoretical information on the labor supply decision in the underground economy is given by Lemieux, Fortin and Fréchette (1994) who use micro data from a survey conducted in Quebec City (Canada). In particular, their study provides some economic insights regarding the size of the distortion caused by income taxation and the welfare system. The results of this study suggest that hours worked in the shadow economy are quite responsive to changes in the net wage in the regular (official) sector. Their empirical results attribute this to a (mis-) allocation of work from the official to the informal sector, where it is not taxed. In this case, the substitution between labor market activities in the two sectors is quite high. These empirical findings indicate, that "participation rates and hours worked in the underground sector also tend to be inversely related to the number of hours worked in the regular sector" (Lemieux, Fortin and Fréchette 1994, p. 235). These findings demonstrate a large negative elasticity of hours worked in the shadow economy with respect both to the wage rate in the regular sector as well as to a high mobility between the sectors.

29. Pioneering work in this area has been done by L. Frey (1972, 1975, 1978, 1980), Cappiello (1986), Lubell (1991), Pozo (1996), Bartlett (1998) and Tanzi (1999). One of the latest surveys or background paper is Hazans (2011) dealing with informal workers across Europe.

30. Compare also one of the latest OECD report with the title "Is Informal Normal: Toward More and Better Jobs" by the OECD (2009). 
Illicit work can take many forms. The underground use of labor may consist of a second job after (or even during) regular working hours. A second form is shadow economy work by individuals who do not participate in the official labor market. A third component is the employment of people (e.g. clandestine or illegal immigrants), who are not allowed to work in the official economy. Empirical research on the shadow economy labor market is even more difficult than of the shadow economy on the value added, since one has very little knowledge about how many hours an average "shadow economy worker" is actually working (from full time to a few hours, only); hence, it is not easy to provide empirical facts. ${ }^{31}$

Kucera and Roncolato (2008, p. 321) also deal with informal employment. They address two issues of crucial importance to labor market policy:

(i) The intensive labor market regulations as one (major) cause of informal employment, and

(ii) the so-called "voluntary" informal employment. Kucera and Roncolato give a theoretical overview on both issues and also a survey of a number of empirical studies, in which mainly the effect of official labor market regulations on informal employment is analyzed, where they find a significant and quantitatively important influence.

\subsection{Two Micro-Studies about the Shadow Economy Labor Market}

To discuss some micro-economic research about the shadow economy labor market two case studies about the size and development of shadow economy labor markets in Denmark and in Germany are presented and discussed. ${ }^{32}$

\subsubsection{The Micro Study of Denmark}

The first study is done by Hvidtfeldt, Jensen and Larsen (2011), which investigates the size and development of undeclared work in Denmark over the years 2008-2010, but also going back to the year 1994. Hvidtfeld, Jensen and Larsen (2011, p. 1) claim that more than half of all Danes purchase undeclared work in the course of a year. The authors got this finding with the help of an interview survey of 2.200 randomly-selected Danes who were conducted by the

31. For developing countries some literature about the shadow labor market exists (Dallago (1990), Pozo (1996), Loayza (1996), Chickering and Salahdine (1991) and OECD (2009)).

32 The selection of these two studies is based on the fact that they use data from 2010 and both provide important and detailed insights, why people choose to demand and supply shadow work. Of course this selection is subjective. Compare also Feld and Larsen (2005, 2008, 2009) and Schneider (2011). 
Rockwool Foundation Research Unit in 2010. According to their survey, 52\% of those questioned had had undeclared work done for them in the previous year and had paid in cash, in kind or through return services. Their survey $(2011$, p. 2) also showed that an additional $28 \%$ would be willing to buy undeclared services, even though they had not actually done so within the previous year. In total, $80 \%$ of the Danish population are potential customers for undeclared work and only $20 \%$ said, they would refuse to pay for undeclared services.

In table 4.1 the proportions of Danish men are shown who carried out undeclared work in the previous 12 month (year 2010). Table 4.3 clearly says that $48 \%$ of such undeclared work is done in the construction sector, followed by agriculture of $47 \%$ and motor vehicle sales and repairs of $43 \%$. The least amount is done in the public and personal services with $26 \%$.

Table 4.1: Proportions of men who had carried out undeclared work in the previous 12 months

\begin{tabular}{|l|l|}
\hline SECTOR & in percent \\
\hline Building and construction & $\mathbf{4 8 \%}$ \\
\hline Agriculture (incl. gardening), fishing and mineral extraction & $47 \%$ \\
\hline Motor vehicle sales and repairs & \\
\hline Energy and water supply & $\mathbf{4 3 \%}$ \\
\hline Manufacturing & $\mathbf{3 8 \% )}$ \\
\hline Transport and telecommunications & $36 \%$ \\
\hline Hotel and restaurant & $31 \%$ \\
\hline Financial and business services & $\mathbf{3 0 \% )}$ \\
\hline Public and personal services & $\mathbf{2 8 \%}$ \\
\hline Retail, wholesale and repair (excluding motor vehicles) & $\mathbf{2 6 \%}$ \\
\hline OVERALL & $\mathbf{2 6 \%}$ \\
\hline
\end{tabular}

Note: Figures in parentheses are based on fewer than 50 observations.

Source: Rockwool Foundation Research Unit, 2011, p. 5

In this study the authors also investigate the amount of undeclared work since the year 1994 and they come to the conclusion that Danes do roughly as much undeclared work today as they did 15 years ago. The latest figures from 2008-2010 show that every forth adult Dane carried out some kind of undeclared work in the course of a year. Those involved spend around three hours per week working on the undeclared labor market. This figure has not changed since the mid 1994. Calculations of the amount of undeclared work in relation to 
GDP also show that the situation remains largely unchanged. Undeclared work today is at a level of $2,8 \%$ in relation to GDP. ${ }^{33}$

Finally what is a quite interesting result of this study, is the acceptance of black labor among the Danish population.

Table 4.2 A: Proportion of the Danish population who find it acceptable that a schoolgirl should earn undeclared income for babysitting, 2007-2008.

$\begin{array}{ll}\text { If she earns DKK } 200 \text { per week } & 84 \% \\ \text { If she earns DKK } 300 \text { per week } & 70 \%\end{array}$

Source: Rockwool Foundation Research Unit, March 2011, p.14

Table 4.2 B: Proportion of the Danish population who find it acceptable that a skilled tradesman should earn undeclared income, 2007-2008.

\begin{tabular}{ll} 
If he earns DKK 10.000 per year & $47 \%$ \\
If he earns DKK 50.000 per year & $27 \%$ \\
\hline
\end{tabular}

Source: Rockwool Foundation Research Unit, March 2011, p. 14.

The Danish population evaluates a school girl who earns some money in the shadow economy, and was asked about the acceptance and the same question war asked about a skilled tradesman. The results are reported in table 4.4. They clearly show that there is a high acceptance of shadow economy labor work for a school girl compared to a well established skilled tradesman with a reasonable high income. Not astonishing for the school girl the acceptance is $70 \%$ earning 300 DKK per week and $84 \%$ earning 200 DKK per week. For the tradesman to earn additional 10.000 DKK per year the acceptance drops down to $47 \%$ (below 50\%) and if he earns more than 50.000 DKK per year the acceptance is only $27 \%$. It is a quite interesting finding which demonstrates that Danes tolerate shadow economy earnings from low income earners but not from high income earners.

33. In this study a lot of interesting facts are reported, like who is working, like distribution of men and women in the shadow economy, like, how much is paid per hour in the different sectors, etc. Also it is investigated whether high income households demand more or less shadow economy work and it seems they demand more. 


\subsubsection{The Micro Study of Germany}

Haigner, Jenewein, Schneider and Wakolbinger (2011) investigate the informal labor supply and demand in Germany for the year 2010. In this study they use data from a representative survey among 2104 German residents, conducted in May 2010. As a matter of fact, questions on illegal behavior like informal labor supply and demand are highly confidential and delicate; hence it is possible that survey respondents who have engaged in such activities do not want to declare that they have done so. In order to encourage more honest answers, the interviewees have been read the following text (translated from German).

"The next set of questions deals with what is called black work. We survey these questions on behalf of a group of independent scientists, who will process the results within a study. By black work they mean the following: One works for somebody and agrees not to pay taxes for the payment. Both partners are better off because no value added tax, income tax or social security contributions are paid. Such procedures are frequently occurring, for example, in cleaning, gardening, baby-sitting, waiting at table, writing or programming. Also, work which is not taxed is prevalent in construction, renovation, car repair and taking care of elderly people."

Moreover, if interviewers recognized that the interviewees hesitated to answer the questions on informal labor supply and demand, they would again note that the interview is confidential and that answers are confidential, anonymous and only for scientific use. The question on informal labor supply was (translated from German) "Have you, during the last year, worked for somebody in the way described above (black work)?" The question on informal labor demand was (again translated from German) "Have you, during the last year, demanded black work?" Moreover, they have asked informal labor suppliers on the reasons for doing so, on the time when they have done such works (working time, weekends, vacations,...), on the sector in which they have worked, on the number of hours they have worked per month and on the estimated hourly wage they have received.

In order to grasp the general attitudes towards informal labor supply and demand, they have asked the survey respondents to declare their accordance with a set of 13 statements on the topic. Possible answers were indicated on a scale ranging from -4 (total disagreement) to +4 (total agreement). Figure 4.1 shows the results. While there seems to be considerable awareness of the fact that informal labor reduces the tax revenues of the state, many people claim, on the other hand, that high tax rates make attractive the informal labor market. Interestingly, many people like informal labor because it is more rapidly available and more flexible than official labor, which is widely perceived to be subject to too strict regulations. 
Moreover, people, on average, do not agree with the statement that informal labor suppliers should be reported to the police, nor would many people report them to the police themselves. This shows that informal labor is, in Germany, perceived as a rather trivial offense.

\section{Figure 4.1: Attitudes towards informal labor supply and demand}

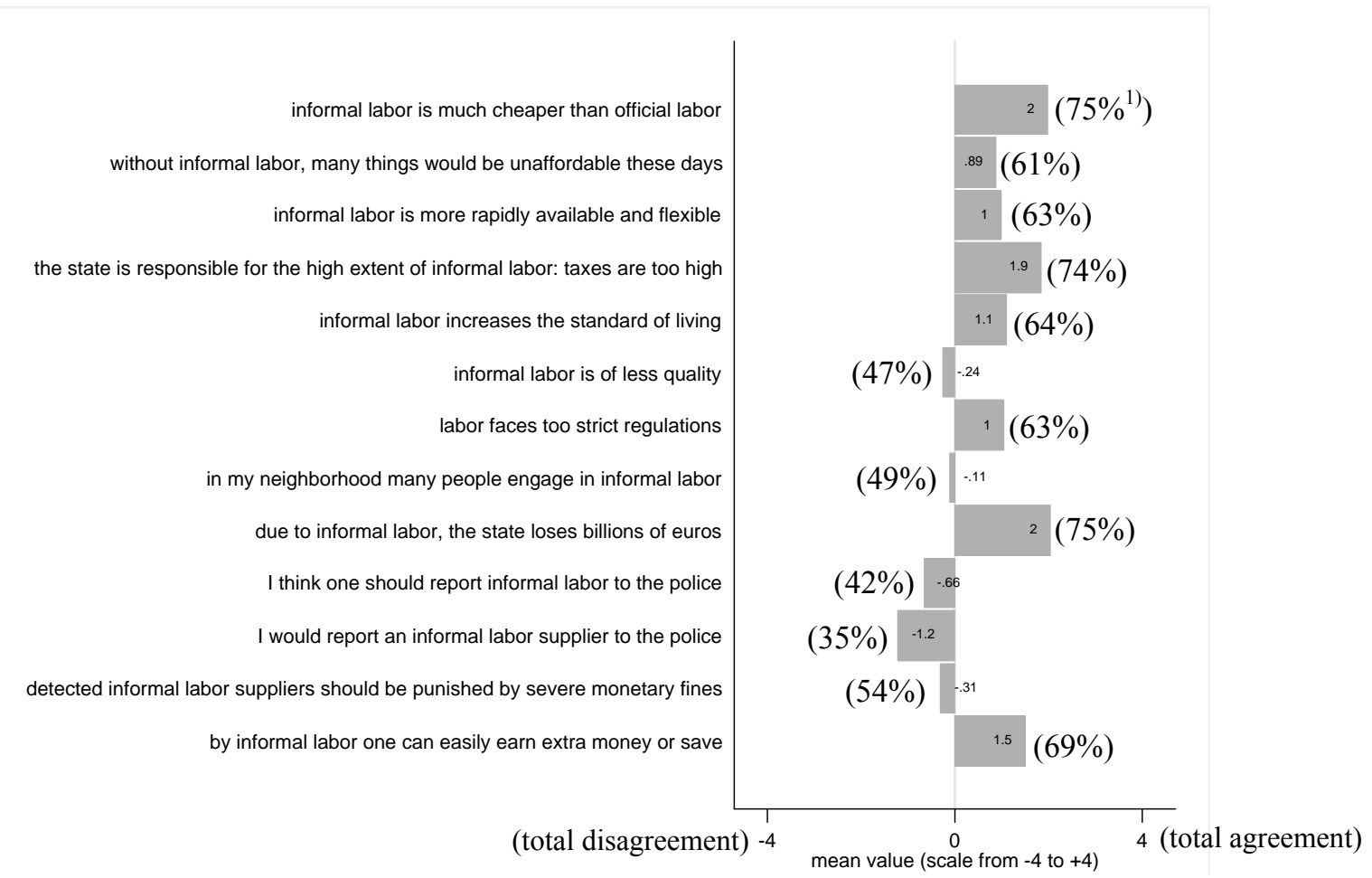

1) in ( ) percenteage points of agreement

Source: Haigner et al. (2012)

\section{(1) Informal Labor Supply}

Out of 2104 respondents, 285 (13.55\%) declared that they have been supplying informal labor during the year before the survey. Among men, the fraction of informal labor suppliers was significantly higher (18.82\%) than among women (8.58\%) (Mann-Whitney U-Test, N=2104, $\mathrm{p}=0.00$ ). Moreover, the authors find above average fractions of informal labor suppliers among the unemployed (29.29\%) and people out of labor force "due to other reasons" $(23.53 \%)$. Among pensioners $(5.10 \%)$ and housewives and housemen $(9.52 \%)$ the fraction is below the average, while it is close to the average among students (14.44\%), apprentices (11.75\%), self-employed persons (15.17\%) and dependent employees (15.60\%). Among persons not having completed compulsory education and those who have completed an apprenticeship, informal labor suppliers are overrepresented (24.24\% and $20.41 \%)$, while they are underrepresented among persons with a university degree $(7.19 \%)$. 


\section{(2) Sectors of Informal Labour Supply}

Figure 4.2 shows in which sectors informal labor supply takes place. Not surprisingly, crafts and technical occupations and private household services have the highest relative importance. In both branches, more than a quarter of informal labor suppliers are engaged. About $15 \%$ of informal labor suppliers declare to be working in other services, gardening/agriculture and construction. Fractions do not add up to $100 \%$ since multiple answers have been allowed.

\section{Figure 4.2: Sectors of informal labor supply}

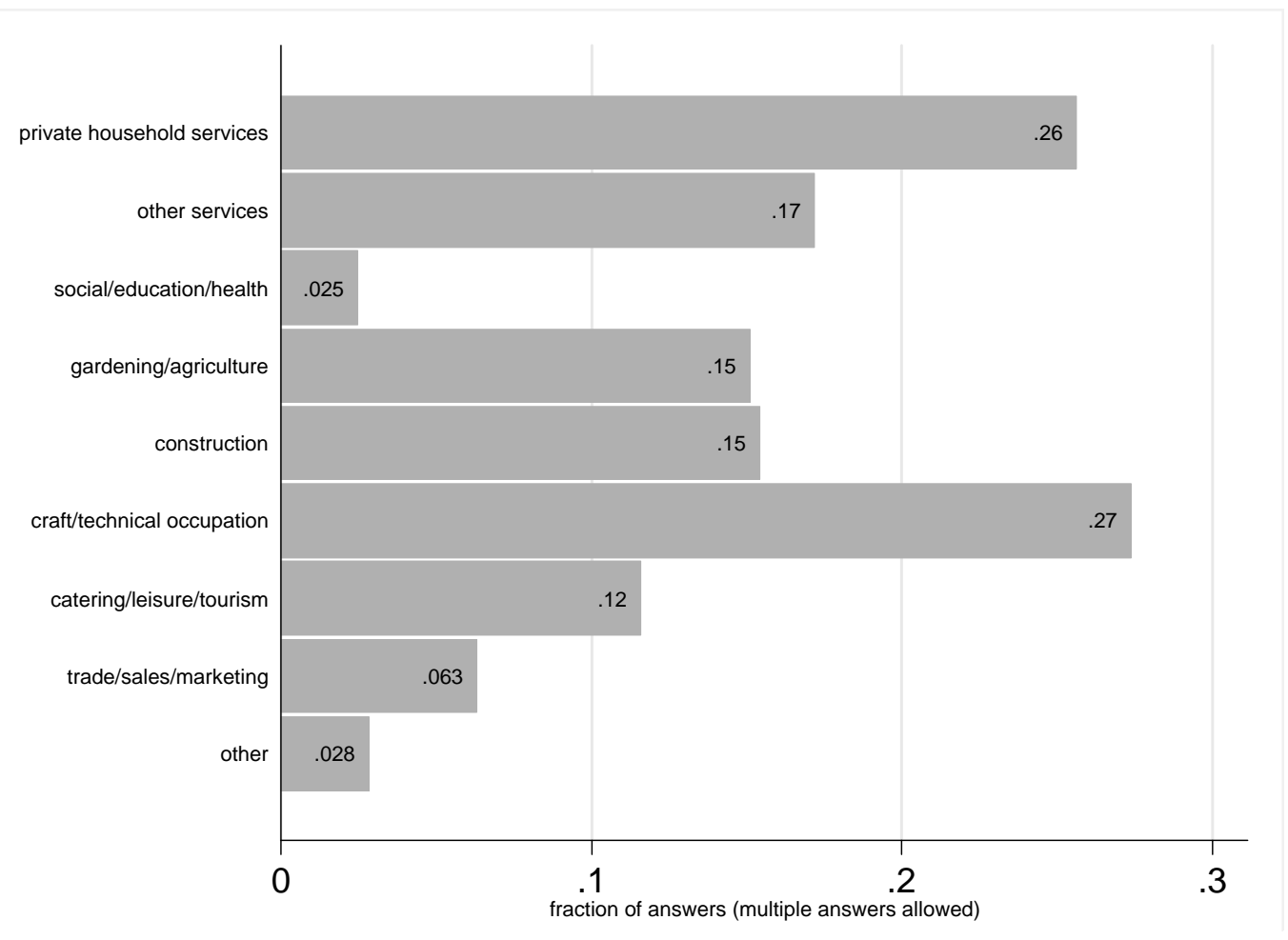

Source: Haigner et al.(2012)

\section{(3) Directly reported reasons}

The authors have directly asked the survey respondents (declaring to engage in informal labor supply) for the reasons for doing so. Again, the results are as expected. Figure 4.3 shows that four in five declare to supply informal labor in order to earn more money. All other noted reasons are far less important. However, it is interesting to see, for example, that one in about eight informal labor suppliers do so because they do not want to lose transfer payments. In the German social system, pensioners as well as unemployment benefit and social assistance 
recipients face a full transfer cut and thus implicit marginal tax rates of $100 \%$ and more if they would officially supply labor.

More than one in five informal labor suppliers claim that a reason for doing so is that others do it as well. This result is in line with our (earlier reported) finding that German residents perceive, in general, informal labor supply and demand as a rather trivial offence. By the same token, slightly more than ten percent of informal labor suppliers claim that they do so because their customers want the demanded work to be done unofficially. Another ten percent say that they like the flexibility of informal labor supply. ${ }^{34}$

\section{Figure 4.3: Directly reported reasons for supplying informal labor}

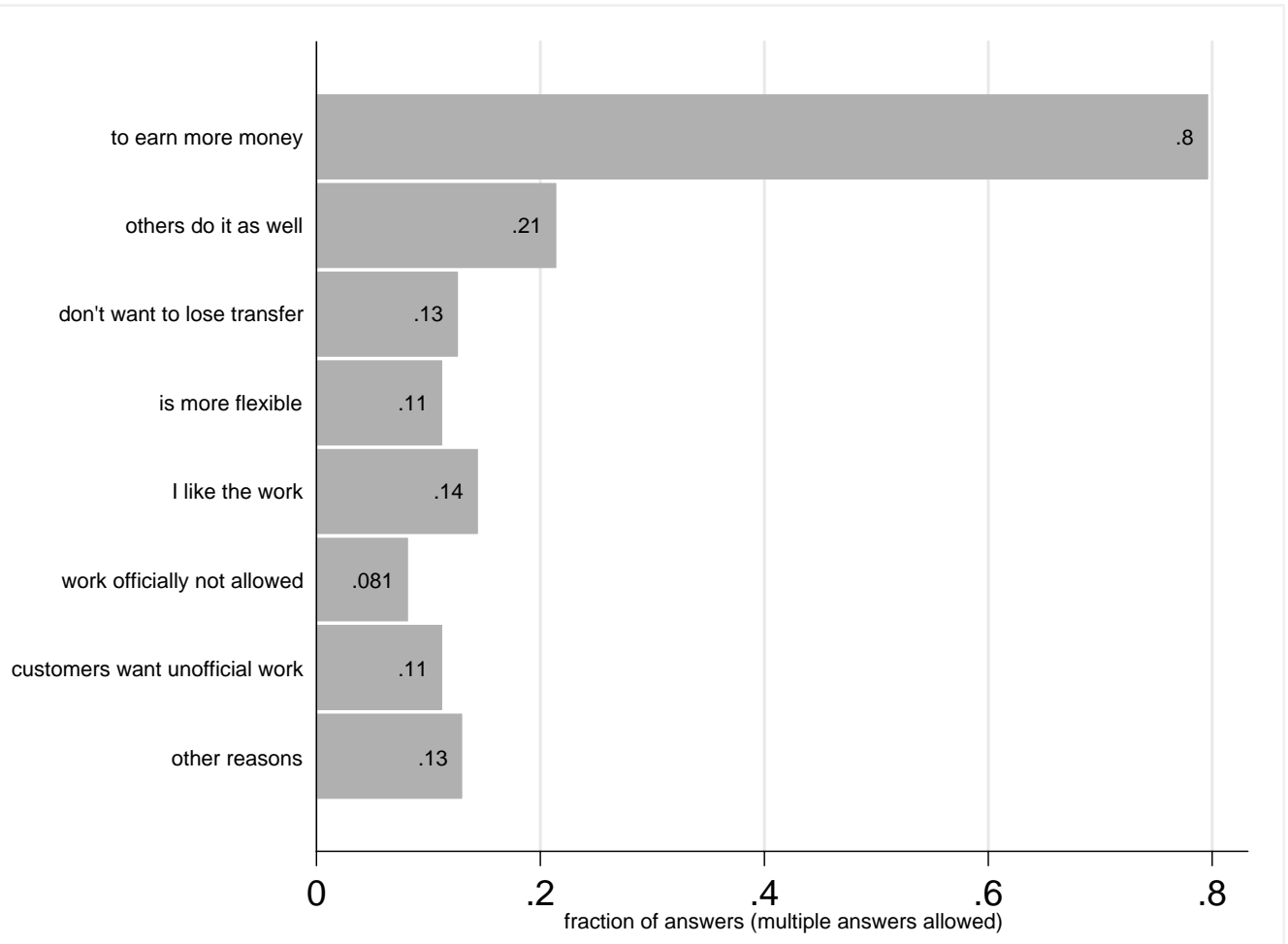

Source: Haigner et al. (2012)

34 In this study also a microeconemetric investigation is undertaken confirming the facts discussed here under ceteris paribus conditions. 


\subsection{Shadow Economy Labor Force}

\subsubsection{World Wide Aspects - Latest Results}

The following results of the shadow economy labor force are based on the OECD and World Bank database on informal employment in major cities and in rural areas, as well as on other sources mentioned in the footnotes of this chapter and the tables. The values of the shadow economy labor force are calculated in absolute terms, and as a percentage of the official labor force, under the assumption that the shadow economy in rural areas is at least as high as in the cities. This is a conservative assumption, since in reality it is likely to be even larger. ${ }^{35}$ Survey techniques and, for some countries, the MIMIC-method and the method of the discrepancy between the official and actual labor force are used for estimation.

One of the latest studies is the OECD (2009) one with the title "Is informal normal?", which provides world wide figures. This OECD study ${ }^{36}$ concludes that in many parts of the world and over the period 1990 to 2007 informal employment is the norm, not the exception,. More than half of all jobs in the non-agricultural sectors of developing countries - over 900 million workers - can be considered informal. If agricultural workers in developing countries are included, the estimates size to roughly 2,000 million people. The share of informal employment is also shown in figures 4.4 for Latin America and South East Asia. In some regions, including Sub-Saharan Africa and South Asia, over $80 \%$ of non-agricultural jobs are informal. Most informal workers in the developing world are self-employed and work independently, or owe and manage very small enterprises. According to the OECD study (2009), informal employment is a result of both, people being excluded from official jobs and people voluntarily opting out of formal structures, e.g. in many middle income countries incentives drive individuals and businesses out of the formal sector.

To summarize, this OECD study clearly comes to the conclusion that informal is really the norm or the normal case 1.8 billion people work in informal jobs, compared to 1.2 billion who benefit from formal contracts and social security protection. Informal economic activity, excluding the agricultural sector, accounts for three quarters of the jobs in Sub-Saharan Africa, more than two thirds in South and South East Asia, half in Latin America, the Middle East

35 The assumption that the shadow economy labour force is at least as high in rural areas as in major cities, is a very modest one and is supported by Lubell (1991). Some authors (e.g., Lubell (1991), Pozo (1996), and Chickering and Salahdine (1991)) argue that the illicit labour force is nearly twice as high in the countryside as in urban areas. But since no (precise) data exists on this ratio, the assumption of an equal size may be justified arguing that such a calculation provides at least minimal figures. 
and North Africa, and nearly one quarter in transition countries. If agriculture is included, the informal share of the economy in the above mentioned regions is even higher (e.g. more than $90 \%$ in South Asia). Also, this OECD study comes to the result that more than 700 million informal workers "survive" on less than $\$ 1.25$ a day and some 1.2 billion on less than $\$ 2$ a day. The study also concludes that the share of informal employment tends to increase during economic turmoil. For example, during the Argentine economic crisis (1999-2002), the countries' "official" economy shrank as by almost one fifth while the share of informal employment expanded from 48 to 52 percent. One can clearly see that even under strong economic growth, the share of non-agricultural employment and, the share of informal employment is strongly rising.

\subsubsection{OECD-Countries}

\subsubsection{General Results}

In Table 4.3 the estimates for the shadow economy labor force in highly developed OECD countries (Austria, Denmark, France, Germany, Italy, Spain and Sweden) are shown. ${ }^{37}$ In Austria the shadow economy labor force has arrived at 500.000 to 750.000 or $16 \%$ of the official labor force (mean value) in the years 1997-1998. In Denmark the development of the 80s and 90 s shows that the part of the Danish population engaged in the shadow economy ranged from $8.3 \%$ of the total labor force (in 1980) to $15.4 \%$ in 1994 - quite a remarkable increase of the shadow economy labor force; it almost doubled over 15 years. In France (in the years 1997/98) the shadow economy labor force reached a size of between 6 and 12\% of the official labor force or between 1.6 and 3.2 million in absolute figures. In Germany this figure rose from 8 to $12 \%$ in 1974 to $19 \%$ and to $22 \%$ (8 millions) in the year 1997/98. For France and Germany this is again a very strong increase in the shadow economy labor force. In other countries the amount of the shadow economy labor force is quite large, too: in Italy $30-48 \%$ (1997-1998), Spain 11.5-32\% (1997-1998) and Sweden 19.8 \% (1997-1998). In the European Union about 30 million people are engaged in shadow economy activities in the years 19971998 and in all European OECD countries 48 million work illicitly.

36 The following results and figures are taken from the OECD (2009), executive summary.

37. Shadow economy labor force consists of estimated full-time "black" jobs, including unregistered workers, illegal immigrants and second "black" jobs. 
Figure 4.4: Informal Employment and GDP in Latin America and Southeast Asia

Part 1: Latin America

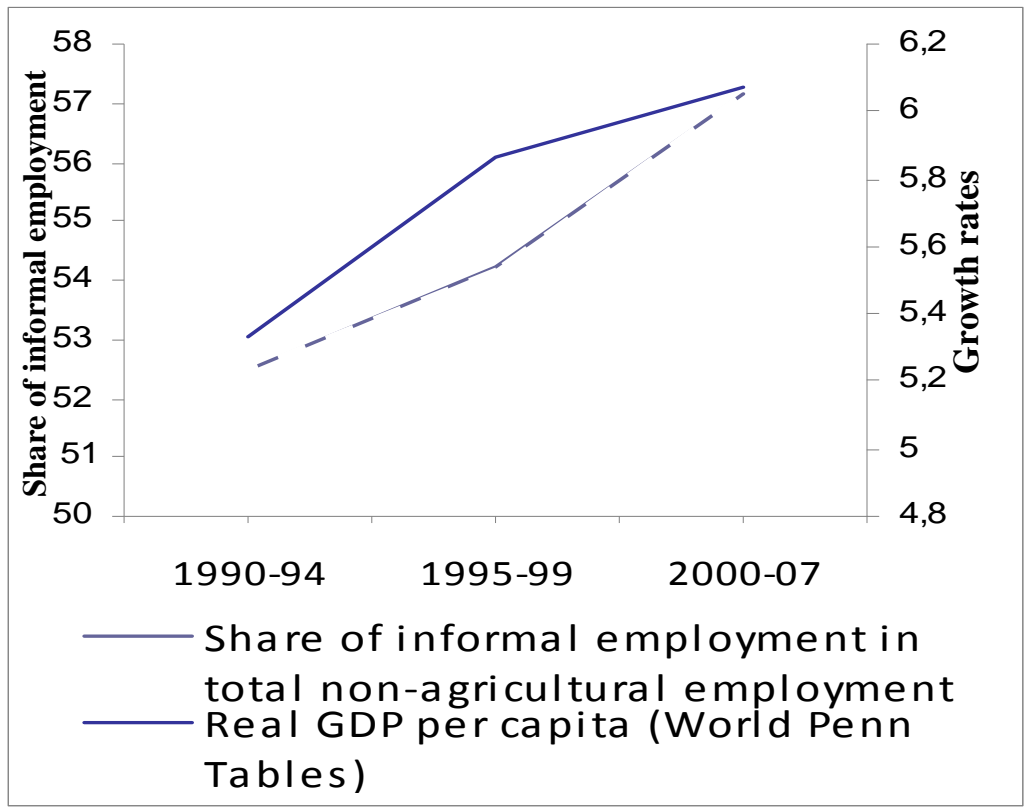

Part 2: Southeast Asia

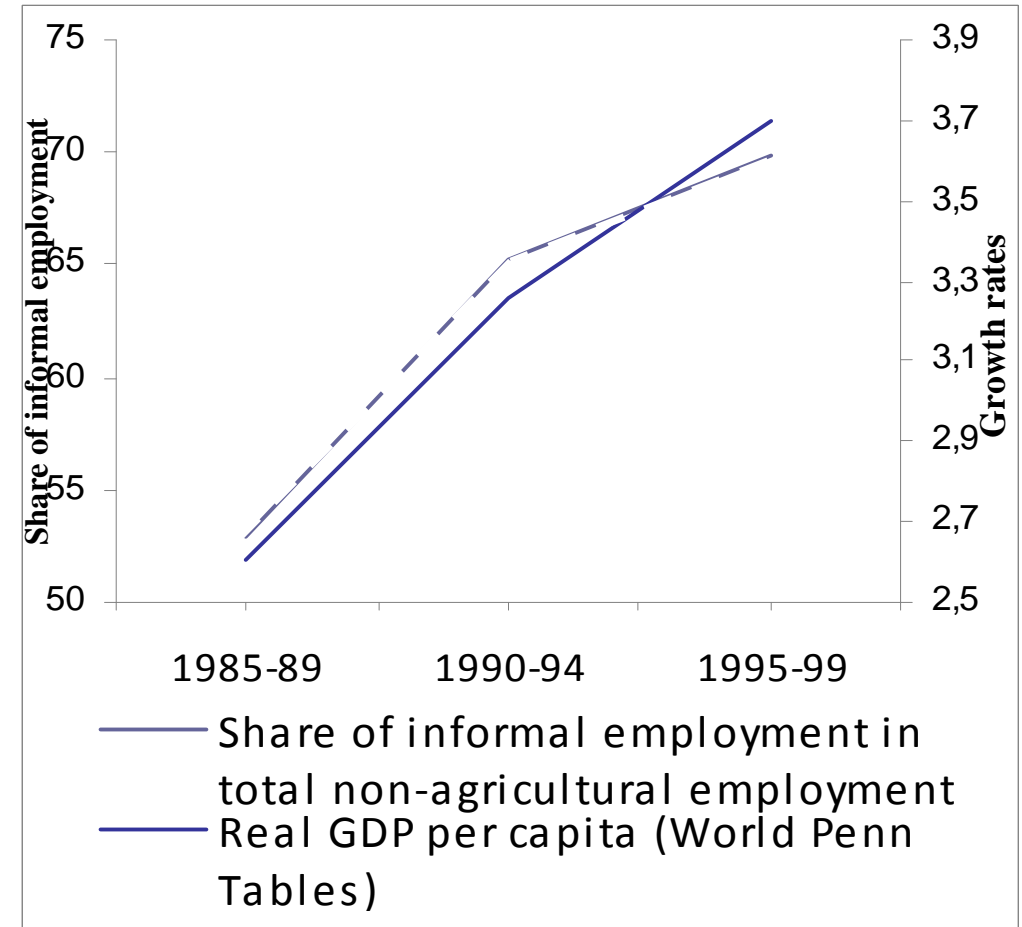

Source: OECD, Is Informal Normal, Paris, 2009. 


\begin{tabular}{|c|c|c|c|c|c|c|c|}
\hline \multicolumn{8}{|c|}{ Table 4.3.: Estimates of the Size of the "Shadow Economy Labor Force" in Some OECD Countries 1974-1998 } \\
\hline Countries & Year & $\begin{array}{l}\text { Official GDP } \\
\text { per capita in } \\
\text { US- } \$^{1)}\end{array}$ & $\begin{array}{l}\text { Total Economy } \\
\text { (Shadow Econ- } \\
\text { omy plus official } \\
\text { GDP per capita } \\
\text { in US-\$) }\end{array}$ & $\begin{array}{l}\text { Size of the Shadow } \\
\text { Economy (in \% of } \\
\text { official GDP) Cur- } \\
\text { rency Demand } \\
\text { Approach }^{2)}\end{array}$ & $\begin{array}{l}\text { Shadow Econ- } \\
\text { omy Labor } \\
\text { Force in } 1000 \\
\text { people }^{3)}\end{array}$ & $\begin{array}{l}\text { Shadow Econ- } \\
\text { omy Partici- } \\
\text { pants in \% of } \\
\text { official Labor } \\
\text { Force }^{4)}\end{array}$ & $\begin{array}{l}\text { Sources of Shadow Economy Labor } \\
\text { Force }\end{array}$ \\
\hline Austria & $\begin{array}{l}90-91 \\
97-98\end{array}$ & $\begin{array}{l}20,636 \\
25,874\end{array}$ & $\begin{array}{l}25,382 \\
29,630\end{array}$ & $\begin{array}{l}5.47 \\
8.93\end{array}$ & $\begin{array}{l}300-380 \\
500-750\end{array}$ & $\begin{array}{c}9.6 \\
16.0\end{array}$ & $\begin{array}{l}\text { Schneider }(1998 \mathrm{a}, \mathrm{b}) \text { and } \\
\text { own calculations }\end{array}$ \\
\hline Denmark & $\begin{array}{l}1980 \\
1986 \\
1991 \\
1994 \\
\end{array}$ & $\begin{array}{l}13,233 \\
18,496 \\
25,946 \\
34,441\end{array}$ & $\begin{array}{l}18,658 \\
26,356 \\
36,558 \\
48,562\end{array}$ & $\begin{array}{c}8.6 \\
9.8 \\
11.2 \\
17.6\end{array}$ & $\begin{array}{l}250 \\
390 \\
410 \\
420\end{array}$ & $\begin{array}{c}8.3 \\
13.0 \\
14.3 \\
15.4\end{array}$ & $\begin{array}{c}\text { Mogensen, et. al. } \\
(1995) \\
\text { and own calculations }\end{array}$ \\
\hline France & $\begin{array}{l}1975-82 \\
1997-98\end{array}$ & $\begin{array}{l}12,539 \\
24,363\end{array}$ & $\begin{array}{l}17,542 \\
34,379\end{array}$ & $\begin{array}{c}6.9 \\
14.9\end{array}$ & $\begin{array}{c}800-1,500 \\
1,400-3,200\end{array}$ & $\begin{array}{l}3.0-6.0 \\
6.0-12.0\end{array}$ & $\begin{array}{l}\text { De Grazia (1983) and } \\
\text { own calculations }\end{array}$ \\
\hline Germany & $\begin{array}{l}1974-82 \\
1997-98 \\
\end{array}$ & $\begin{array}{l}11,940 \\
26,080 \\
\end{array}$ & $\begin{array}{ll}17,911 \\
39,634 \\
\end{array}$ & $\begin{array}{ll}10.6 \\
14.7 \\
\end{array}$ & $\begin{array}{l}3,000-4,000 \\
7,000-9,000 \\
\end{array}$ & $\begin{array}{c}8.0-12.0 \\
19.0-23.0 \\
\end{array}$ & $\begin{array}{l}\text { De Grazia (1983), F. Schneider (1998a, } \\
\text { b) and own calculations }\end{array}$ \\
\hline Italy & $\begin{array}{c}1979 \\
1997-98 \\
\end{array}$ & $\begin{array}{c}8,040 \\
20,361 \\
\end{array}$ & $\begin{array}{l}11,736 \\
29,425 \\
\end{array}$ & $\begin{array}{l}16.7 \\
27.3 \\
\end{array}$ & $\begin{array}{l}4,000-7,000 \\
6,600-11,400 \\
\end{array}$ & $\begin{array}{l}20.0-35.0 \\
30.0-48.0 \\
\end{array}$ & $\begin{array}{c}\text { Gaetani-d'Aragona (1979) and } \\
\text { own calculations }\end{array}$ \\
\hline Spain & $\begin{array}{l}1979-80 \\
1997-98 \\
\end{array}$ & $\begin{array}{c}5,640 \\
13,791 \\
\end{array}$ & $\begin{array}{c}7,868 \\
19,927 \\
\end{array}$ & $\begin{array}{l}19.0 \\
23.1\end{array}$ & $\begin{array}{l}1,250-3,500 \\
1,500-4,200 \\
\end{array}$ & $\begin{array}{c}9.6-26.5 \\
11.5-32.3 \\
\end{array}$ & $\begin{array}{l}\text { Ruesga (1984) and } \\
\text { own calculations }\end{array}$ \\
\hline Sweden & $\begin{array}{c}1978 \\
1997-98 \\
\end{array}$ & $\begin{array}{l}15,107 \\
25,685 \\
\end{array}$ & $\begin{array}{l}21,981 \\
37,331 \\
\end{array}$ & $\begin{array}{l}13.0 \\
19.8 \\
\end{array}$ & $\begin{array}{c}750 \\
1,150 \\
\end{array}$ & $\begin{array}{c}13.0-14.0 \\
19.8\end{array}$ & De Grazia (1983) and own calculations \\
\hline $\begin{array}{c}\text { European } \\
\text { Union }\end{array}$ & $\begin{array}{c}1978 \\
1997-98\end{array}$ & $\begin{array}{c}9,930 \\
22,179\end{array}$ & $\begin{array}{l}14,458 \\
32,226 \\
\end{array}$ & $\begin{array}{l}14.5 \\
19.6 \\
\end{array}$ & $\begin{array}{l}15,000 \\
30,000\end{array}$ & - & De Grazia (1983) and own calculations \\
\hline $\begin{array}{l}\text { OECD }(E u- \\
\text { rope })\end{array}$ & $\begin{array}{c}1978 \\
1997-98\end{array}$ & $\begin{array}{c}9,576 \\
22,880\end{array}$ & $\begin{array}{l}14,162 \\
33,176\end{array}$ & $\begin{array}{l}15.0 \\
20.2\end{array}$ & $\begin{array}{l}26,000 \\
48,000\end{array}$ & - & De Grazia (1983) and own calculations \\
\hline \multicolumn{8}{|c|}{$\begin{array}{l}\text { 1) Source: OECD, Paris, various years } \\
\text { 2) Source: Own calculations from Schneider }(2000,2001) \text {. } \\
\text { 3) Estimated full-time jobs, including unregistered workers, illegal immigrants, and second jobs. } \\
\text { 4) In percent of the population aged 20-69, survey method. }\end{array}$} \\
\hline
\end{tabular}




\begin{tabular}{|c|c|c|c|c|c|c|}
\hline \multirow[t]{2}{*}{ Year } & \multicolumn{2}{|c|}{ Germany } & \multicolumn{2}{|c|}{ Austria } & \multicolumn{2}{|c|}{ Switzerland } \\
\hline & $\begin{array}{l}\text { Full time shadow } \\
\text { economy workers }\end{array}$ & $\begin{array}{c}\text { Illegal foreign } \\
\text { workers }\end{array}$ & $\begin{array}{l}\text { Full time shadow } \\
\text { economy workers }\end{array}$ & $\begin{array}{l}\text { Illegal foreign } \\
\text { workers }\end{array}$ & $\begin{array}{l}\text { Full time shadow } \\
\text { economy workers }\end{array}$ & $\begin{array}{c}\text { Illegal foreign } \\
\text { workers }\end{array}$ \\
\hline 1995 & 7.320 & 878 & 575 & 75 & 391 & 55 \\
\hline 1996 & 7.636 & 939 & 617 & 83 & 426 & 61 \\
\hline 1997 & 7.899 & 987 & 623 & 86 & 456 & 67 \\
\hline 1998 & 8.240 & 1.039 & 634 & 89 & 462 & 69 \\
\hline 1999 & 8.524 & 1.074 & 667 & 93 & 484 & 74 \\
\hline 2000 & 8.621 & 1.103 & 703 & 99 & 517 & 79 \\
\hline 2001 & 8.909 & 1.149 & 734 & 104 & 543 & 84 \\
\hline 2002 & 9.182 & 1.194 & 746 & 109 & 556 & 88 \\
\hline 2003 & 9.420 & 1.225 & 769 & 112 & 565 & 90 \\
\hline 2004 & 9.023 & 1.103 & 789 & 114 & 560 & 89 \\
\hline 2005 & 8.549 & 1.002 & 750 & 104 & 520 & 82 \\
\hline 2006 & 8.124 & 952 & 716 & 98 & 493 & 78 \\
\hline 2007 & 8.206 & 961 & 709 & 97 & 490 & 77 \\
\hline 2008 & 8.154 & 955 & 679 & 93 & 471 & 74 \\
\hline 2009 & 8.272 & 968 & 713 & 98 & 484 & 76 \\
\hline \multicolumn{7}{|c|}{ Source: Own calculations (2010). } \\
\hline $\begin{array}{l}\text { 1) Ex } \\
\text { hours worl } \\
\text { workers. T }\end{array}$ & $\begin{array}{l}\text { tions: These numbe } \\
\text { the shadow econor } \\
\text { culation is only do }\end{array}$ & $\begin{array}{l}\text { of full time shad } \\
\text { Most people, w } \\
\text { o make compari }\end{array}$ & $\begin{array}{l}\text { economy domestic } \\
\text { vork in the shadow } \\
\text { to official statistic }\end{array}$ & $\begin{array}{l}\text { rkers are a fiction } \\
\text { nomy in these th }\end{array}$ & $\begin{array}{l}\text { cause these are calc } \\
\text { countries, are "part-t }\end{array}$ & $\begin{array}{l}\text { ed from the millio } \\
\text { " shadow econom }\end{array}$ \\
\hline
\end{tabular}


These figures demonstrate that the shadow economy labor market is lively and may provide an explanation, why for example in Germany, one could observe such a high and persistent unemployment up to the year 2007.

Additionally, Table 4.3 contains a preliminary calculation of the total GDP per capita (including the official and the shadow economy GDP per capita) in US-\$. In all countries investigated, total GDP per capita is much higher - on average in all countries around $40 \%$. This clearly shows that the productivity in the shadow economy is roughly as high as in the official economy - a clear indication, that the work effort (i.e. the incentive to work effectively) is as strong in the shadow economy as in the official one. In general these results demonstrate that the shadow economy labor force has reached a remarkable size in the developing countries as well as in highly developed OECD countries, even though the calculation still might have many errors.

Data about the share of the shadow economy labor force in highly developed countries is really scarce. For three countries (compare Table 4.4), I have some data, these are Austria, Germany and Switzerland, where I have a shadow economy labor force calculated in full time shadow economy workers ${ }^{38}$. If I consider Germany, the full time shadow economy workers were about 7 million in 1995 and increased to 9.4 million in 2004 and decreased again to 8.2 million in 2009. If I consider the illegal foreign shadow economy full time workers in Germany, they are roughly one twelfth of the full time German or legal resident shadow workers. In 1995 they were 878,000, increased to 1.2 million in 2002 and decreased again to 968,000 in 2009. In Austria, the full time shadow economy workers were 575,000 in 1995 , increased to 798,000 in 2004 and have decreased since to 713,000 in 2009 . Table 4.4 clearly shows that the figures of the shadow economy work force in these highly developed countries Austria, Germany and Switzerland, are much smaller than the ones in developing countries. Finally these results clearly demonstrate that the illegal immigrated working force is small in Austria, Germany and Switzerland like the results in subchapter 4.5 .5 and in table 4.7 for other countries.

38. These numbers of full time shadow economy workers are a "fiction", because most $(2 / 3 !)$ people in these three countries are "part time" shadow economy workers. They are only calculated here to make the figure comparable to the work force in the official economy. Let me repeat, these full time shadow economy workers do not exist for Germany, Austria and Switzerland. 


\subsubsection{Developing Countries - Earlier Results ${ }^{39}$}

Table 4.5 shows the results of countries in Africa over the nineties. Gambia has the largest shadow economy labor force with $80 \%$ of the official one, followed by Guinea with $79 \%$, Benin with $76.9 \%$, Rwanda with $75 \%$, and the Republic of Congo with $50 \%{ }^{40}$ Zimbabwe has the lowest rate of illicit work with $33.9 \%$ of the official labor force. For African countries, the figures show considerable variation and should really be seen as first and preliminary results over 1997-1999. Under the assumption that this informal or shadow economy labor force is as productive as the official economy and contributes per capita a similar added value, the shadow economy GNP can be calculated, which is also shown in Table 4.4. Gambia has the largest shadow economy as a percentage of official GNP with $41.2 \%$, followed by Guinea with $36.9 \%$, and Rwanda with $38.7 \%$. On average, the supply of illicit work in these 33 African countries is $54.2 \%$ (of the official labor force) and $24.6 \%$ of the population.

Table 4.6 illustrates the results for some Asian countries over 1997-1999. Here, China, India, and Indonesia have to be examined more closely, as they are the three largest countries in Asia (regarding population). In China, it is estimated that 160 million people work in the shadow economy $-21.9 \%$ of the official labor force. ${ }^{41}$ In India, 217 million people work illicitly $-50 \%$ of the official labor force. In Indonesia, 36.7 million people engage in shadow economic activities, this corresponds to $37.4 \%$ of the official labor force. In Pakistan, 29.4 million people or 60\% work in the shadow economy. One realizes that in Asia the shadow economy labor force is quite high, a result also found in the OECD (2009) study. On the whole, the shadow economy labor force in these Asian countries makes up $46.5 \%$ of the official labor force and $19.6 \%$ of the population.

39. This parts follows closely Schneider and Enste (2002, part 5, pp. 43-51).

40. These high values strongly indicate that a considerable number of these illicit workers also have (at least part-time) jobs in the official economy. Yet, the number of these 'double-job-holders' (official and unofficial at the same time) is unknown and may differ from country to country. The ratio of the shadow economy labour force as a percentage of the official one should be interpreted very cautiously, since it is unclear what this ratio actually stands for. Hence, an interpretation is very difficult. In addition, making comparisons between different countries is very complicated and such comparisons provide only a very crude picture. Maybe the rate of the shadow economy labour force as a percentage of the population is a somewhat better gauge.

41. The figure for China should be interpreted with great care as this country still has a communist regime with some regions under a capitalist system. 
In Table 4.7 some Latin and South American states are shown over 1997-1999. In absolute terms, Brazil has the highest shadow economy labor force with 37.4 million (49.2\% of the official labor force), followed by Colombia with 9.7 million or 53.8\%. Both Ecuador with $58.8 \%$, and Peru with $54.6 \%$, have a quite high rate of illicit work. Chile has the lowest rate, with $40 \%$, as well as Paraguay with $41 \%$, and El Salvador with $47.3 \%$ of the official labor force. Overall, the shadow economy labor force in these nine countries is $49.6 \%$ of the official labor force and $20.3 \%$ of the population.

\subsubsection{Transition Countries - Earlier Results}

Nine transition countries were analyzed (see Table 4.8.) over 1997 to 1999. Armenia has the highest rate with an illicit labor force of $75.5 \%$ of the official labor force, followed by Croatia with 70\%, and Bulgaria with 63\%. In absolute figures, Russia has by far the largest shadow economy labor force among the transition countries with 32.9 million illegal workers, followed by Rumania with 4.7 million, and Kazakhstan with 2.8 million. Slovenia has the lowest black labor force with $31 \%$ of the official labor force. Generally, the shadow economy labor force in these nine countries is $49 \%$ of the official labor force and $23.9 \%$ of the population. Here the findings should be interpreted with great care, as these "transition" countries switched from a planned economy to a market economy and due to this official statistics had a lot of preliminary figures and calculation methods were difficult to use. 
Table 4.5: Shadow Economy Labor Force in Africa

\begin{tabular}{|c|c|c|c|c|c|c|c|c|c|}
\hline \multirow[b]{2}{*}{ Country } & \multicolumn{3}{|c|}{ Informal employment (1998) } & \multirow[b]{2}{*}{$\begin{array}{l}\text { Popula- } \\
\text { tion (1997) } \\
\text { millions }\end{array}$} & \multicolumn{2}{|c|}{ Labor force (1997) } & \multirow{2}{*}{$\begin{array}{l}\text { Shad. ec. } \\
\text { GNP in } \\
\text { billion \$, } \\
1998\end{array}$} & \multirow{2}{*}{$\begin{array}{l}\text { Official } \\
\text { GNP in } \\
\text { billion } \$ \\
1998\end{array}$} & \multirow[b]{2}{*}{$\begin{array}{l}\text { Shad. ec. } \\
\text { GNP as \% of } \\
\text { official GNP }\end{array}$} \\
\hline & Millions & $\begin{array}{l}\text { As \% of official } \\
\text { labor force }\end{array}$ & $\begin{array}{l}\text { In \% of } \\
\text { population }\end{array}$ & & Millions & $\begin{array}{l}\text { As \% of } \\
\text { popula- } \\
\text { tion }\end{array}$ & & & \\
\hline Angola & 1.90 & 35.7 & 16.3 & 11.66 & 5.3 & 45.45 & 646 & 4,000 & 16.2 \\
\hline Benin & 2.00 & 76.9 & 34.5 & 5.80 & 2.6 & 44.83 & 758 & 2,200 & 34.5 \\
\hline Botswana & 0.30 & 45.0 & 19.6 & 1.53 & 0.7 & 45.75 & 1,080 & 5,600 & 19.3 \\
\hline Burkina Faso & 3.40 & 65.0 & 32.5 & 10.47 & 5.2 & 49.67 & 816 & 2,600 & 31.4 \\
\hline Cameroon & 3.50 & 61.7 & 25.1 & 13.94 & 5.7 & 40.89 & 2,135 & 8,700 & 24.5 \\
\hline Chad & 1.30 & 38.0 & 18.2 & 7.15 & 3.4 & 47.55 & 299 & - & - \\
\hline Congo & 0.60 & 50.3 & 22.1 & 2.71 & 1.1 & 40.59 & 414 & 1,900 & 21.8 \\
\hline Côte d'Ivoire & 3.40 & 60.3 & 23.9 & 14.21 & 5.7 & 40.11 & 2,380 & 10,100 & 23.6 \\
\hline $\begin{array}{l}\text { Dem. Rep. of Con- } \\
\text { go }\end{array}$ & 15.70 & 80.0 & 33.6 & 46.71 & 19.6 & 41.96 & 1,727 & 5,400 & 32.0 \\
\hline Ethiopia & 15.70 & 61.0 & 26.3 & 59.75 & 25.7 & 43.01 & 1,570 & 6,200 & 25.3 \\
\hline Gabon & 0.30 & 58.0 & 26.1 & 1.15 & 0.5 & 43.48 & 1,251 & - & - \\
\hline Gambia & 0.50 & 80.0 & 42.4 & 1.18 & 0.6 & 50.85 & 170 & 413 & 41.2 \\
\hline Ghana & 6.10 & 72.3 & 33.9 & 17.98 & 8.5 & 47.27 & 2,379 & 7,200 & 33.0 \\
\hline Guinea & 2.60 & 79.0 & 37.6 & 6.92 & 3.3 & 47.69 & 1,404 & 3,800 & 36.9 \\
\hline Kenya & 6.00 & 40.8 & 21.0 & 28.61 & 14.6 & 51.03 & 2,100 & 9,800 & 21.4 \\
\hline Lesotho & 0.31 & 38.8 & 15.4 & 2.01 & 0.8 & 39.80 & 185 & 1,200 & 15.4 \\
\hline Liberia & 0.40 & 35.0 & 13.8 & 2.89 & 1.2 & 41.52 & - & - & - \\
\hline
\end{tabular}


Table 4.5: Shadow Economy Labor Force in Africa - cont.

\begin{tabular}{|c|c|c|c|c|c|c|c|c|c|}
\hline \multirow[b]{2}{*}{ Country } & \multicolumn{3}{|c|}{ Informal employment (1998) } & \multirow[b]{2}{*}{$\begin{array}{l}\text { Popula- } \\
\text { tion (1997) } \\
\text { millions }\end{array}$} & \multicolumn{2}{|c|}{ Labor force (1997) } & \multirow{2}{*}{$\begin{array}{l}\text { Shad. ec. } \\
\text { GNP in } \\
\text { billion \$, } \\
1998\end{array}$} & \multirow{2}{*}{$\begin{array}{l}\text { Official } \\
\text { GNP in } \\
\text { billion } \\
1998\end{array}$} & \multirow[b]{2}{*}{$\begin{array}{l}\text { Shad. ec. } \\
\text { GNP as \% of } \\
\text { official GNP }\end{array}$} \\
\hline & Millions & $\begin{array}{l}\text { As \% of official } \\
\text { labor force }\end{array}$ & $\begin{array}{l}\text { In \% of } \\
\text { population }\end{array}$ & & Millions & $\begin{array}{l}\text { As } \% \text { of } \\
\text { popula- } \\
\text { tion }\end{array}$ & & & \\
\hline Madagascar & 3.90 & 57.5 & 27.6 & 14.15 & 6.7 & 47.35 & 1,014 & 3,700 & 27.4 \\
\hline Malawi & 2.50 & 51.7 & 24.3 & 10.28 & 4.9 & 47.67 & 500 & 2,100 & 23.8 \\
\hline Mali & 1.80 & 36.0 & 17.5 & 10.29 & 5.0 & 48.59 & 450 & 2,600 & 17.3 \\
\hline Mauritania & 0.50 & 41.0 & 20.3 & 2.46 & 1.1 & 44.72 & 205 & 1,000 & 20.5 \\
\hline Namibia & 0.33 & 47.1 & 20.4 & 1.62 & 0.7 & 43.21 & 652 & 3,200 & 20.4 \\
\hline Niger & 2.30 & 51.0 & 23.5 & 9.80 & 4.6 & 46.94 & 437 & - & - \\
\hline Nigeria & 23.40 & 48.9 & 19.8 & 117.90 & 47.9 & 40.63 & 17,780 & 36,400 & 48.8 \\
\hline Rwanda & 3.20 & 75.0 & 40.5 & 7.90 & 4.2 & 53.16 & 736 & 1,900 & 38.7 \\
\hline Senegal & 2.50 & 62.4 & 28.4 & 8.79 & 4.0 & 45.51 & 1,325 & 4,800 & 27.6 \\
\hline Sierra Leone & 1.30 & 70.0 & 27.4 & 4.75 & 1.8 & 37.89 & 182 & 702 & 25.9 \\
\hline Sudan & 4.60 & 42.6 & 16.3 & 28.30 & 10.8 & 38.16 & 1,333 & 8,200 & 16.3 \\
\hline Tanzania & 6.80 & 42.2 & 21.7 & 31.32 & 16.1 & 51.40 & 1,476 & 6,800 & 21.7 \\
\hline Togo & 0.70 & 38.9 & 16.1 & 4.34 & 1.8 & 41.47 & 226 & 1,400 & 16.1 \\
\hline Tunisia & 2.00 & 57.1 & 21.5 & 9.30 & 3.5 & 37.63 & 4,272 & 19,400 & 21.5 \\
\hline Uganda & 5.80 & 56.4 & 28.5 & 20.32 & 10.2 & 50.20 & 1,798 & - & - \\
\hline Zimbabwe & 1.80 & 33.9 & 15.7 & 11.47 & 5.3 & 46.21 & 1,082 & 6,900 & 15.7 \\
\hline $\begin{array}{c}\text { Average over } 33 \\
\text { countries }\end{array}$ & 3.9 & 54.2 & 24.6 & & & 44.9 & & & 25.7 \\
\hline
\end{tabular}

Source: Schneider and Enste (2002, chapter 5), based on World Bank, Africa Region Live Database, http://www.worldbank.org/html/extdr/regions.htm. 
Table 4.6: Shadow Economy Labor Force in Asia

\begin{tabular}{|c|c|c|c|c|c|c|c|c|c|}
\hline \multirow[b]{2}{*}{ Country } & \multicolumn{3}{|c|}{ Informal employment (1998) } & \multirow{2}{*}{$\begin{array}{l}\text { Population } \\
\text { (1998) mil- } \\
\text { lions }\end{array}$} & \multicolumn{2}{|c|}{ Labor force (1998) } & \multirow{2}{*}{\begin{tabular}{ll}
\multicolumn{2}{l|}{ Informal } \\
GNP in \\
billion \\
1998
\end{tabular}} & \multirow{2}{*}{$\begin{array}{l}\text { Official GNP } \\
\text { in billion } \$ \text {, } \\
1998\end{array}$} & \multirow{2}{*}{$\begin{array}{l}\text { Informal } \\
\text { GNP as \% } \\
\text { of official } \\
\text { GNP }\end{array}$} \\
\hline & Millions & $\begin{array}{l}\text { As } \% \text { of la- } \\
\text { bor force }\end{array}$ & $\begin{array}{l}\text { As } \% \text { of } \\
\text { population }\end{array}$ & & Millions & $\begin{array}{l}\text { As } \% \text { of } \\
\text { population }\end{array}$ & & & \\
\hline China & 162.40 & 21.9 & 13.1 & $1,238.60$ & 743.0 & 59.99 & 138,327 & $1,055,000$ & 13.1 \\
\hline India & 217.20 & 50.4 & 22.2 & 979.70 & 431.0 & 43.99 & 95,568 & 427,400 & 22.4 \\
\hline Indonesia & 36.70 & 37.4 & 18.0 & 203.70 & 98.0 & 48.11 & 24,956 & 221,500 & 11.3 \\
\hline Mongolia & 0.42 & 44.0 & 16.2 & 2.60 & 1.0 & 38.46 & 169 & 1,000 & 16.9 \\
\hline Nepal & 8.60 & 78.1 & 37.6 & 22.90 & 11.0 & 48.03 & 1,803 & 4,800 & 37.6 \\
\hline Pakistan & 29.40 & 60.0 & 22.3 & 131.60 & 49.0 & 37.23 & - & - & - \\
\hline Philippines & 9.80 & 30.6 & 13.0 & 75.20 & 32.0 & 42.55 & 11,520 & 88,400 & 13.1 \\
\hline Sri Lanka & 2.50 & 31.3 & 13.3 & 18.80 & 8.0 & 42.55 & 一 & 一 & 一 \\
\hline Yemen & 3.30 & 65.0 & 19.9 & 16.60 & 5.0 & 30.12 & 990 & 4,400 & 22.5 \\
\hline $\begin{array}{c}\text { Average of } 9 \\
\text { countries }\end{array}$ & 52.3 & 46.5 & 19.5 & & & 43.4 & & & 19.5 \\
\hline
\end{tabular}

Source: Own calculations based on World Bank, World Development Indicators, http://www.worldbank.org/html/extdr/regions.htm. 
Table 4.7: Shadow Economy Labor Force in Latin and South America

\begin{tabular}{|c|c|c|c|c|c|c|c|c|c|}
\hline \multirow[b]{2}{*}{ Country } & \multicolumn{3}{|c|}{ Informal employment (1998) } & \multirow{2}{*}{$\begin{array}{l}\text { Population } \\
\text { (1998) mil- } \\
\text { lions }\end{array}$} & \multicolumn{2}{|c|}{ Labor force (1998) } & \multirow{2}{*}{$\begin{array}{l}\text { Informal } \\
\text { GNP in } \\
\text { billion \$, } \\
1998\end{array}$} & \multirow{2}{*}{$\begin{array}{l}\text { Official GNP } \\
\text { in billion } \$ \text {, } \\
1998\end{array}$} & \multirow{2}{*}{$\begin{array}{l}\text { Informal } \\
\text { GNP as \% of } \\
\text { official GNP }\end{array}$} \\
\hline & Millions & $\begin{array}{l}\text { As \% of labor } \\
\text { force }\end{array}$ & $\begin{array}{l}\text { As } \% \text { of } \\
\text { population }\end{array}$ & & Millions & $\begin{array}{l}\text { As \% of } \\
\text { population }\end{array}$ & & & \\
\hline Bolivia & 1.54 & 51.3 & 19.5 & 7.90 & 3.0 & 37.97 & 1,540 & 7,400 & 20.8 \\
\hline Brazil & 37.40 & 49.2 & 22.5 & 165.90 & 76.0 & 45.81 & - & - & - \\
\hline Chile & 2.40 & 40.0 & 16.2 & 14.80 & 6.0 & 40.54 & 11,544 & 73,400 & 15.7 \\
\hline Colombia & 9.70 & 53.8 & 23.8 & 40.80 & 18.0 & 44.12 & 25,220 & 106,100 & 23.8 \\
\hline Ecuador & 2.94 & 58.8 & 24.1 & 12.20 & 5.0 & 40.98 & 4,482 & 18,600 & 24.1 \\
\hline El Salvador & 1.40 & 47.3 & 23.0 & 6.10 & 3.0 & 49.18 & 2,590 & 11,200 & 23.1 \\
\hline Guatemala & 2.01 & 50.3 & 18.6 & 10.80 & 4.0 & 37.04 & 3,296 & 16,800 & 19.6 \\
\hline Paraguay & 0.80 & 41.0 & 15.4 & 5.20 & 2.0 & 38.46 & 1,408 & 9,200 & 15.3 \\
\hline Peru & 4.91 & 54.6 & 19.8 & 24.80 & 9.0 & 36.29 & 12,079 & 61,100 & 19.8 \\
\hline $\begin{array}{c}\text { Average of } 9 \\
\text { countries }\end{array}$ & 7.0 & 49.6 & 20.3 & & & 41.2 & & & 20.3 \\
\hline
\end{tabular}

Source: Schneider and Enste (2002, chapter 5) based on World Bank, World Development Indicators, http://www.worldbank.org/html/extdr/regions.htm. 
Table 4.8: Shadow Economy Labor Force in Some Transition Countries

\begin{tabular}{|c|c|c|c|c|c|c|c|c|c|}
\hline \multirow[b]{2}{*}{ Country } & \multicolumn{3}{|c|}{ Informal employment (1998) } & \multirow[b]{2}{*}{$\begin{array}{l}\text { Popula- } \\
\text { tion (1998) } \\
\text { millions } \\
\end{array}$} & \multicolumn{2}{|c|}{ Labor force (1998) } & \multirow[b]{2}{*}{$\begin{array}{l}\text { Informal } \\
\text { GNP in bil- } \\
\text { lion } \$, 1998\end{array}$} & \multirow[b]{2}{*}{$\begin{array}{l}\text { Official GNP } \\
\text { in billion } \$ \text {, } \\
1998\end{array}$} & \multirow{2}{*}{\begin{tabular}{l}
\multicolumn{2}{l|}{ Informal } \\
GNP as \% \\
of official \\
GNP
\end{tabular}} \\
\hline & Millions & $\begin{array}{l}\text { As } \% \text { of la- } \\
\text { bor force }\end{array}$ & $\begin{array}{ll}\text { As } \% & \text { of } \\
\text { population }\end{array}$ & & Millions & $\begin{array}{l}\text { As } \% \text { of } \\
\text { population }\end{array}$ & & & \\
\hline Armenia & 1.51 & 75.5 & 39.7 & 3.80 & 2.0 & 52.63 & 725 & 1,800 & 40.3 \\
\hline Bulgaria & 2.52 & 63.0 & 30.4 & 8.30 & 4.0 & 48.19 & 3,100 & 10,100 & 30.7 \\
\hline Croatia & 1.40 & 70.0 & 31.1 & 4.50 & 2.0 & 44.44 & 6,328 & 20,700 & 30.6 \\
\hline Georgia & 1.10 & 36.7 & 20.4 & 5.40 & 3.0 & 55.56 & 1,023 & 5,100 & 20.1 \\
\hline Kazakhstan & 2.80 & 40.0 & 17.9 & 15.60 & 7.0 & 44.87 & 3,668 & 19,400 & 18.9 \\
\hline Kyrgyzstan & 0.80 & 40.0 & 17.0 & 4.70 & 2.0 & 42.55 & 280 & 1,600 & 17.5 \\
\hline Rumania & 4.70 & 42.7 & 20.9 & 22.50 & 11.0 & 48.89 & 6,533 & 31,300 & 20.9 \\
\hline $\begin{array}{l}\text { Russian Federa- } \\
\text { tion }\end{array}$ & 32.90 & 42.2 & 22.4 & 146.90 & 78.0 & 53.10 & 75,670 & 337,900 & 22.4 \\
\hline Slovenia & 0.31 & 31.0 & 15.5 & 2.00 & 1.0 & 50.00 & 3,026 & 19,400 & 15.6 \\
\hline $\begin{array}{l}\text { Average of } 9 \text { coun- } \\
\text { tries }\end{array}$ & 5.3 & 49.0 & 23.9 & & & 48.9 & & & 24.1 \\
\hline
\end{tabular}

Source: Schneider and Enste (2002, Chapter 5) based on World Bank, World Development Indicators, http://www.worldbank.org/html/extdr/regions.htm 


\subsubsection{Developing and Transition Countries - Latest Results}

Compared to the first estimates presented in the subchapters 4.3.3 and 4.3.4 there have been some newer studies with respect to estimate the size and development of the shadow economy labour force ${ }^{42}$. Kucera and Roncolato $(2008$, p.321) deal with informal employment. They address issues of crucial importance to labour market policy; first, the intensive labour market regulation is one major cause of informal employment, and second, the so called voluntary informal employment. Kucera and Roncolato give a theoretical overview on both issues and also a survey of a number of empirical studies, in which the effect of the official labour market regulations on informal employment is analyzed, where they find a significant and quantitatively important influence.

In Table 4.9 the share of informal employment in total non-agricultural employment by fiveyear period and by region is presented. From the table one clearly sees that in all regions the share of informal employment has remarkably increased over time. The share of informal employment in South- and Middle-American countries in the period of 1985-1989 was 32.4\% and increased in the period of 2000-2007 to 50.1\%. In 34 Asian countries informal employment rose in the period of $1985-1989$ from $55.9 \%$ to $70.2 \%$ from $2000-2007$. In the 42 African countries the share of informal employment (in percent of total non agricultural employment) was $40.3 \%$ from $1985-1989$, and increased to $60.5 \%$ in $2000-2007$. Table 4.9 clearly demonstrates that there is a very strong positive trend in the share of informal employment (in percent of total non agricultural employment).

Table 4.10 provides the share of informal employment in total non-agricultural employment by country, region and gender. If one splits up the share of informal employment (in percent of total non agricultural employment) by gender, I generally observe, that the share of women is significantly higher than the share of men. In North Africa (countries Algeria, Morocco, Tunisia, Egypt) the share of informal employment of women is $43.3 \%$ and the one of men $49.3 \%$ over the period 1990-1999. In Sub-Saharan Africa the share of women is $84.1 \%$, the one of men $63.0 \%$. In Latin America the share of women is $56.2 \%$ and the share of men $47.1 \%$. Only in the region of West Asia and in the transition countries the share of men of informal employment is higher than the one of women. In West Asia (countries Lebanon, West Bank and Gaza Strip, Syria, Turkey, Yemen) the share of women is $31.1 \%$, the share of

\footnotetext{
${ }^{42}$ See also Feld and Schneider (2010), Schneider, Buehn and Montenegro (2010), Williams (2010 a, 2010 b, $2011 \mathrm{a}, 2011 \mathrm{~b})$ and Hazans (2011).
} 
men 43.4\%. In the Transition countries (Kyrgyzstan, Moldova, Russia) the share of women is $22.3 \%$ and the share of men $27.2 \%$. I also realise some remarkable differences. In general the share of informal employment is rather large worldwide and certainly has severe policy implications.

\subsection{Further Indicators of the Shadow Labor Force}

In this part some additional indicators of the shadow economy labor force are discussed, as there are no exact measures of the shadow economy labor force, all the following additional measures which serve as proxies.

\subsubsection{The Share of Self-Employed in total Employment}

Figure 4.5: Share of Self Employed in Total Employment (average: from 1995 to 2008 or the latest year available)

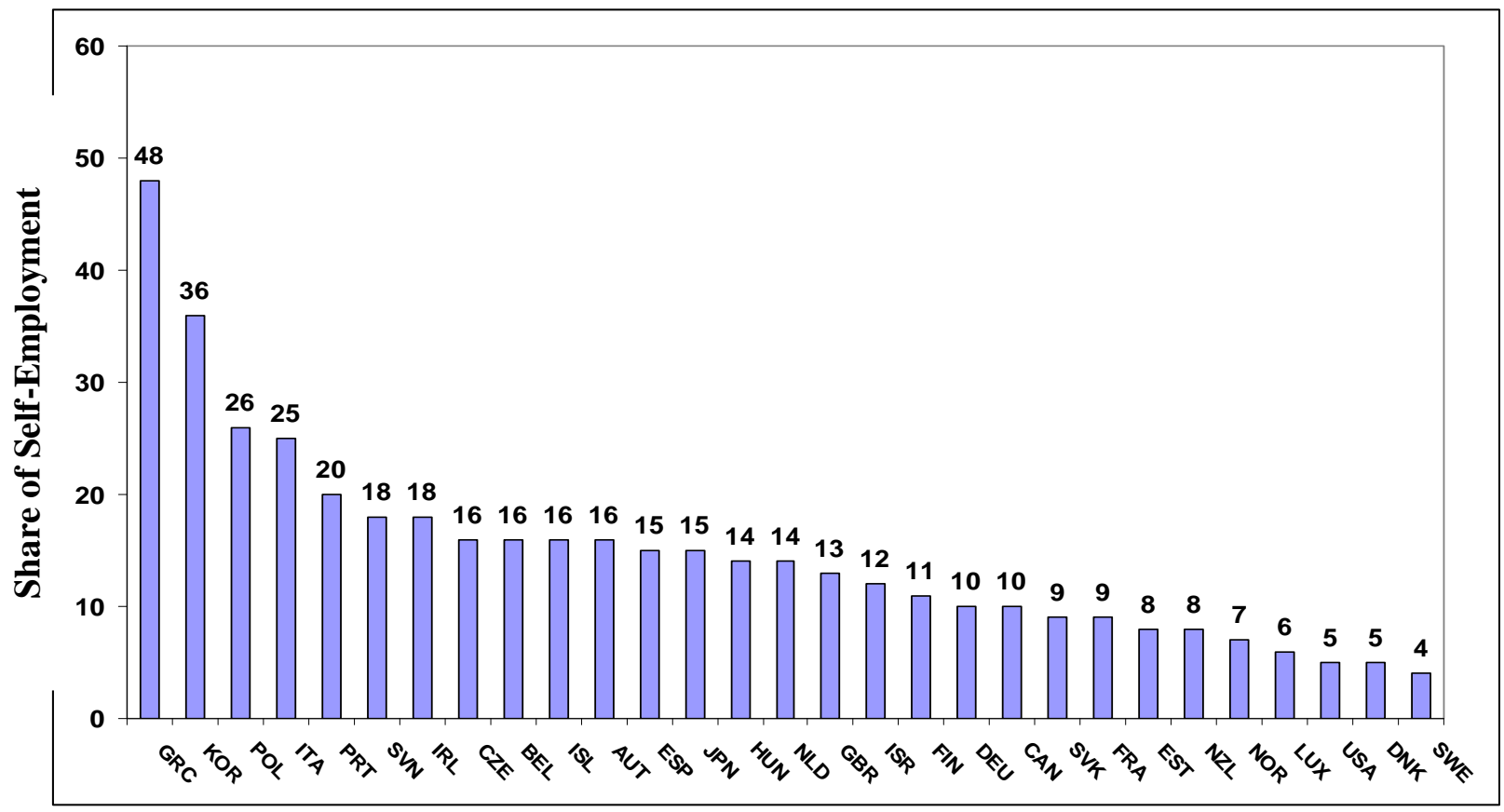

Source: OECD, STAN database, 2010, Paris; quoted from OECD (1022), p. 17, Figure 7.

The share of self employment in total employment can be seen as one indicator of the shadow economy labor force. If I consider Figure 4.5 I clearly see, that Greece, Korea, Poland, Italy, Portugal have the highest share of self employed (in percent of total employed) with a value of $48 \%$ for Greece, a value of $26 \%$ and $25 \%$ for Poland and Italy respectively. As these values are highly correlated with the size of the shadow economy it is quite obvious that at least a great part of this self employed work in the shadow economy, (too). 
Table 4.9: Share of Informal Employment in Total Non-Agricultural Employment by five-year period in \%

\begin{tabular}{|c|c|c|c|c|}
\hline \multirow{2}{*}{ Region } & \multicolumn{4}{|c|}{$\begin{array}{l}\text { Average Share of Informal Employment in \% of } \\
\text { Lokal Non Agricultural Employment over }\end{array}$} \\
\hline & 1985-89 & 1990-94 & 1995-99 & 2000-07 \\
\hline 22 South- and Middle American Countries & 32.4 & 35.4 & 40.3 & 50.1 \\
\hline 34 Asian Countries & 55.9 & 60.4 & 65.4 & 70.2 \\
\hline 42 African Countries & 40.3 & 47.1 & 52.4 & 60.5 \\
\hline 21 Transition Countries & 30.9 & 32.3 & 35.4 & 40.2 \\
\hline
\end{tabular}

Source: OECD 2009, pages 34-35; and Charmes $(2002,2007,2008)$ for the ILO Women and Men in the Informal Economy, 2002.

For the most recent period: Heintz and Chang (2007) for the ILO, and for West Asia: Charmes (2007 and 2008). 
Table 4.10: $\quad$ Share of Informal Employment in Total Non-Agricultural Employment, by country, region and gender (in percent), 1990s and 2000s

\begin{tabular}{|c|c|c|c|c|}
\hline Region & $1990-15$ & & 2000-200 & \\
\hline & Women & Men & Women & Men \\
\hline North Africa & 43.3 & 49.3 & & \\
\hline Algeria & 40.6 & 43.1 & & \\
\hline Morocco & 46.8 & 44.0 & & \\
\hline Tunesia & 39.2 & 53.2 & & \\
\hline Egypt & 46.5 & 56.9 & 38.6 & 47.2 \\
\hline Sub-Saharan Africa & 84.1 & 63.0 & 77.1 & 62.6 \\
\hline Benin & 97.3 & 87.0 & & \\
\hline Chad & 95.2 & 59.5 & & \\
\hline Guinea & 86.7 & 65.6 & & \\
\hline Kenya & 83.1 & 59.1 & & \\
\hline Mali & & & 89.2 & 74.2 \\
\hline South Africa & 58.4 & 43.6 & 64.9 & 51.0 \\
\hline Latin America & 56.2 & 47.1 & 59.5 & 55.4 \\
\hline Bolivia & 74.4 & 55.0 & & \\
\hline Brazil & 67.3 & 54.7 & 52.3 & 50.2 \\
\hline Chile & 43.9 & 30.9 & & \\
\hline Colombia & 44.0 & 34.1 & & \\
\hline Costa Rica & 48.0 & 42.1 & & \\
\hline Dominican Republic & 49.7 & 46.5 & & \\
\hline Ecuador & & & 76.9 & 73.2 \\
\hline El Salvador & 68.6 & 45.7 & & \\
\hline Guatemala & 69.4 & 46.5 & & \\
\hline Honduras & 65.5 & 73.6 & & \\
\hline Mexico & 55.0 & 54.3 & 53.5 & 47.8 \\
\hline Panama & 40.8 & 35.5 & 50.4 & 48.7 \\
\hline Peru & & & 72.0 & 65.1 \\
\hline Venezuela & 47.3 & 46.7 & 52.1 & 47.5 \\
\hline South and Southeast Asia & 72.7 & 70.2 & & \\
\hline India & 85.7 & 82.9 & & \\
\hline Indonesia & 77.2 & 78.0 & & \\
\hline Philippines & 73.4 & 70.8 & & \\
\hline Thailand & 54.3 & 49.1 & & \\
\hline West Asia & 31.1 & 43.4 & 35.4 & 44.4 \\
\hline Lebanon & & & 60.0 & 44.4 \\
\hline West Bank and Gaza Strip & & & 20.2 & 46.8 \\
\hline Syria & 34.6 & 42.8 & & \\
\hline Turkey & 19.1 & 29.1 & 32.2 & 33.4 \\
\hline Yemen & 39.7 & 58.2 & 29.3 & 52.8 \\
\hline Transition countries & & & 22.3 & 27.2 \\
\hline Kyrgyzstan & & & 40.9 & 47.1 \\
\hline Moldova & & & 18.4 & 28.0 \\
\hline Russia & & & 7.6 & 9.6 \\
\hline
\end{tabular}

Source: OECD 2009, page 47; and Charmes (2002), for the ILO Women and Men in the Informal Economy, 2002. For the most recent period: Heintz and Chang (2007) for the ILO, and for West Asia: 


\subsubsection{The Share of Employees not covered by Social Security Contributions}

In Table 4.11 the share of employees without social security contributions are shown for some European countries. If I compare the single countries in Table 4.11 I clearly realise that there are vast differences between the listed countries where in some the share of employees without any social security advantage is pretty high. The leader is Poland with a value between 65 and $57 \%$ in the years 2007 and 2008, followed by France with 51,9 \% and then followed by Spain with 41,5\%. Again the values in Table 4.3 give some indication about the size of the shadow economy labor force, as it is quite plausible that at least some of these work in the shadow economy.

Table 4.11: Share of Employees not Covered by Social Security Contributions

\begin{tabular}{|l|c|c|}
\hline & \multicolumn{2}{|c|}{ Share of non-insured employees in } \\
\hline Country & 2007 & 2008 \\
\hline Austria & & 34,5 \\
\hline Belgium & 35,4 & 36,2 \\
\hline Czech Republic & 38,8 & 40,4 \\
\hline Estonia & 40,8 & 33,9 \\
\hline Finland & 34,6 & 23,5 \\
\hline France & 23,0 & -- \\
\hline Greece & 51,9 & 37,3 \\
\hline Hungary & 37,1 & 42,4 \\
\hline Iceland & 40,6 & 13,3 \\
\hline Ireland & 13,4 & 40,3 \\
\hline Italy & 39,8 & 39,3 \\
\hline Luxembourg & 40,0 & 32,6 \\
\hline Netherlands & 34,6 & 21,6 \\
\hline Norway & 17,7 & 13,2 \\
\hline Poland & 12,2 & 57,0 \\
\hline Portugal & 65,3 & 38,5 \\
\hline Slovak Republic & 35,1 & 38,5 \\
\hline Slovenia & 39,1 & 25,2 \\
\hline Spain & 24,7 & 41,4 \\
\hline Sweden & 41,5 & 22,0 \\
\hline & 22,7 & \\
\hline
\end{tabular}

Source: OECD calculation based on EU-SILC 2007 and 2008, quoted from OECD (2011), p. 18, Table 1. 


\subsubsection{The Share of Workers without an Employment Contract}

In Figure 4.6 the share of workers without an employment contract is shown for various European countries. The leading country is Turkey with $44 \%$, followed by Ireland $39 \%$ and Greece $39 \%$, then Israel $38 \%$. The lowest countries are Sweden and Finland with only 2 or 1 $\%$ share of workers without an employment contract.

Figure 4.6: Share of Workers Without an Employment Contract, 2006

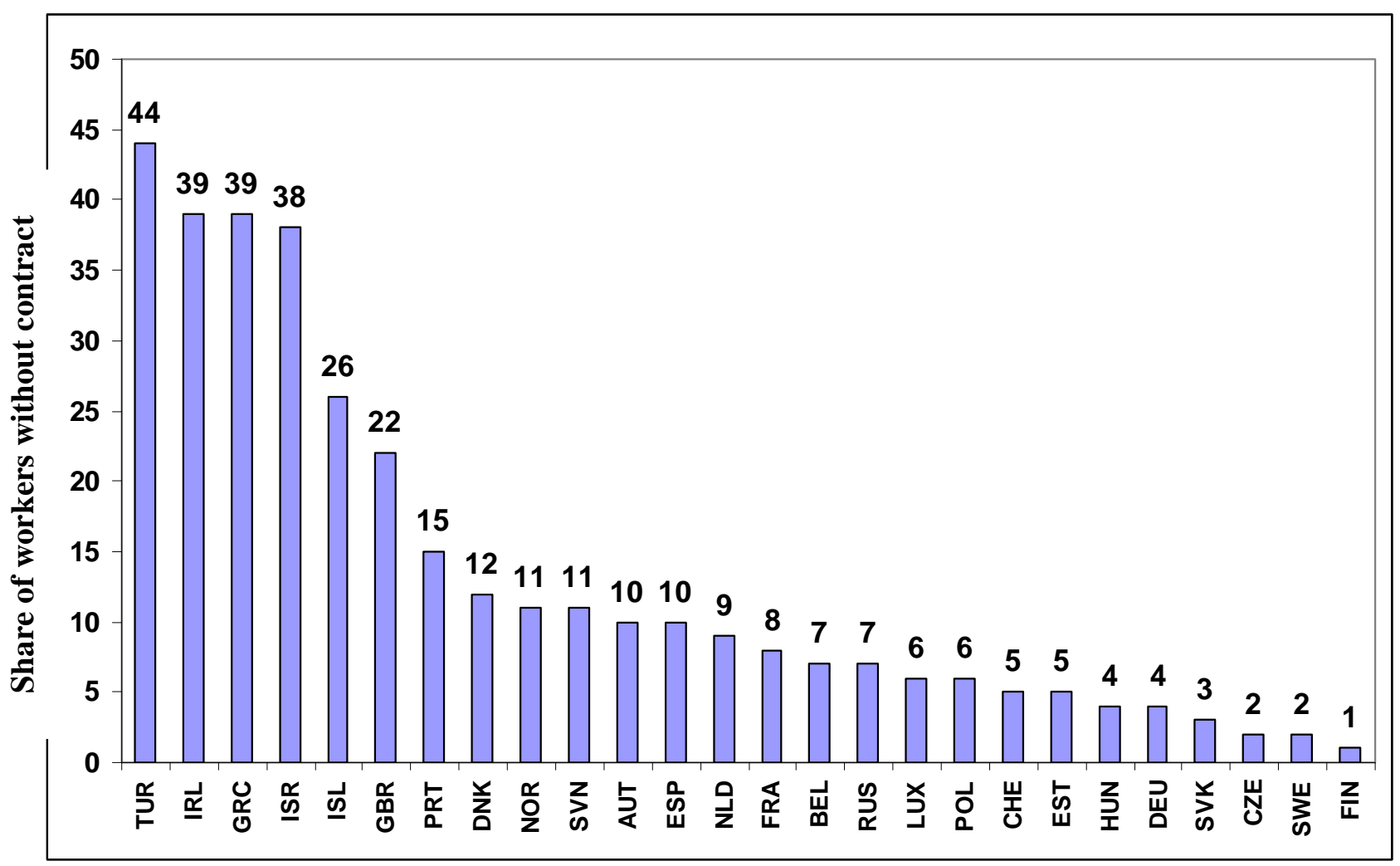

Source. European Social Survey (ESS), 2008, quoted from OECD (2011), p. 18, Figure 8.

\subsubsection{Summary of the Measures of Informal Employment}

An OECD study (2008) focuses on informal employment in seven OECD countries, the Czech Republic, Hungary, Korea, Mexico, Poland and the Slovak Republic and Turkey. Table 4.12 which is taken from this OECD study, nicely shows the alternative measures of informal employment and undeclared work. It is grouped in employees in informal job and own account workers, unpaid family workers, multiple job holders with undeclared income. The highest values for almost all of these seven categories has Mexico, followed by Turkey and 
then by Korea. Table 4.12 clearly shows, how difficult the informal or shadow economy labor force measurement is and how difficult the problems are. In all categories there might be some shadow economy labor work, but it is very difficult to evaluate how large this figure is.

Table 4.12: Alternative Measures of Informal Employment and Undeclared Work, Year 2006

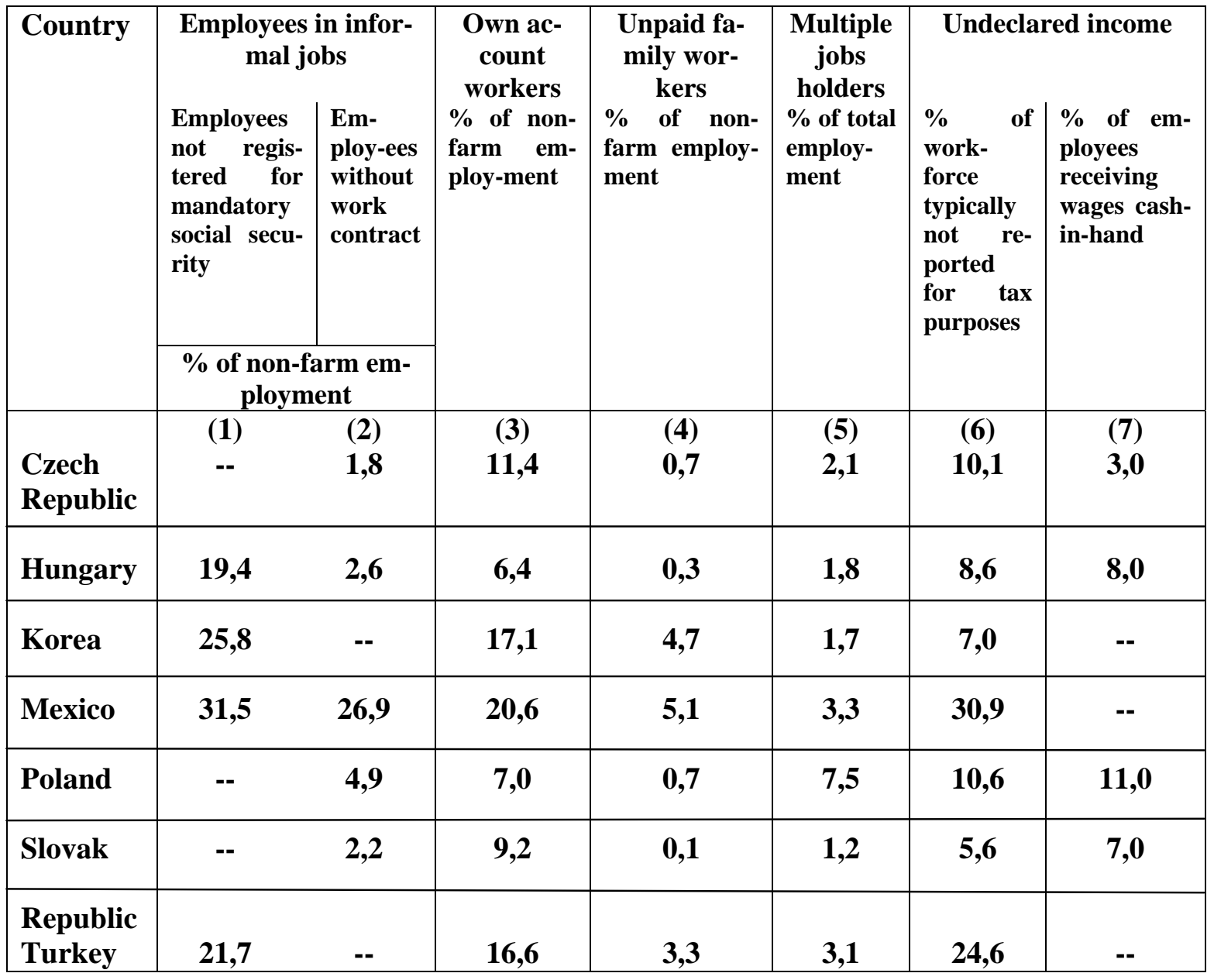

Source: OECD (2008), Paris, quoted from OECD (2011), p. 20, Table 3.1.

\subsubsection{Shadow Economy Workers with Illegal Immigrant Background}

In a number of European countries we find figures about shadow economy workers coming from illegal immigrants. A first estimate has been undertaken again by OECD (2011) and is shown in Figure 4.7. Considering these figures one realizes that the size again is increased with $4,4 \%$ of total employment the highest in Greece, followed by the United States with $3,15 \%$, by Italy $2 \%$ and at the lowest end are Norway and Sweden with $0,5 \%$ or $0,4 \%$ of 
total employment. This table "confirms" the values of a similar size in table 4.2 for Germany, Switzerland and Austria. Both tables clearly show that illegal immigrant employment takes place, but from the size perspective it is rather small for most countries.

Figure 4.7: Illegal employed immigrants as a share of total employment ${ }^{1}$

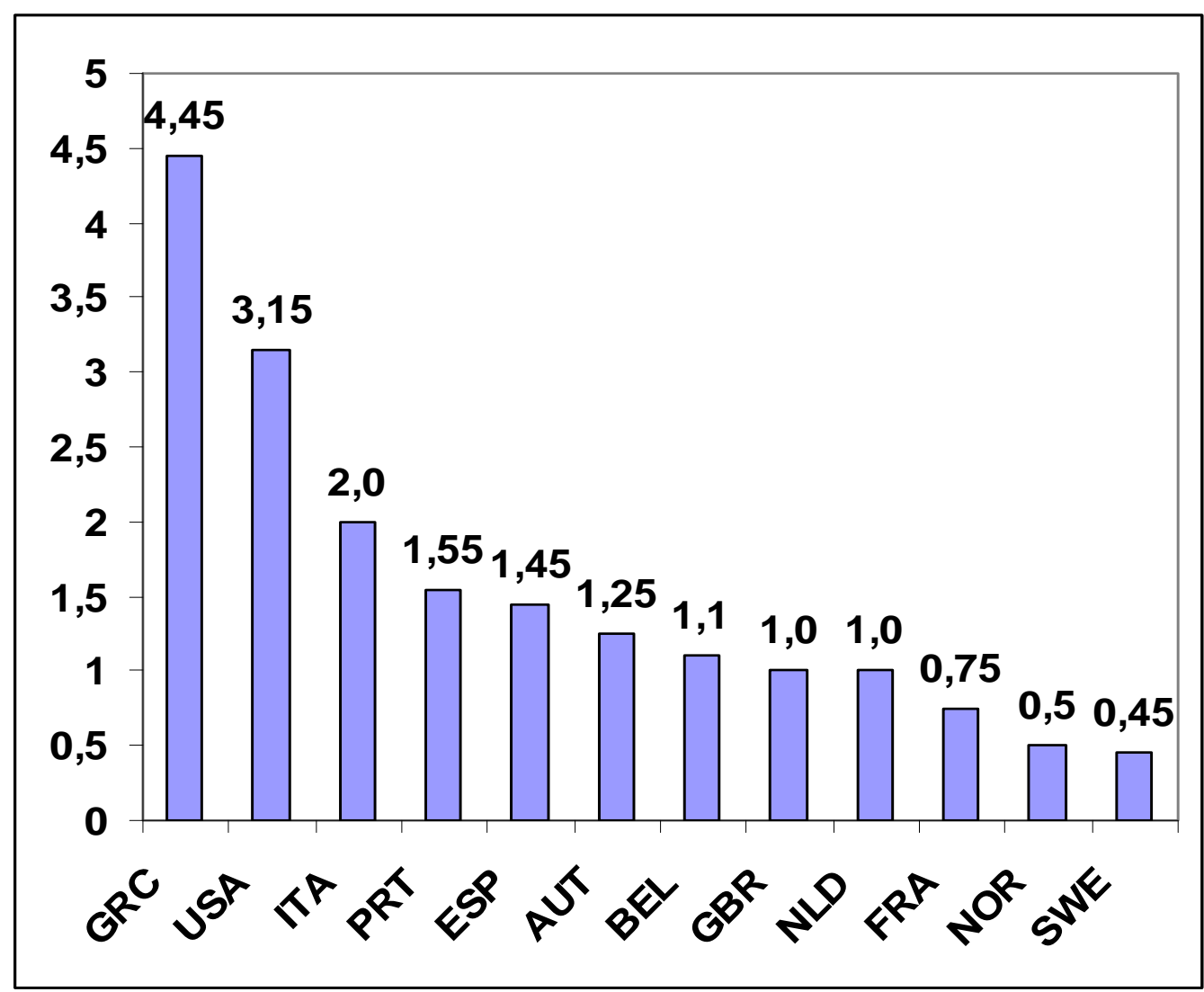

${ }^{1}$ The estimates of the number of employed illegal immigrants are calculated using the number of irregular migrants and assuming the same employment rate for illegal immigrants as for legal migrants.

Source: OECD Calculations based on OECD International Migration Outlook (2009) and OECD Economic Outlook Database (2010), quoted from OECD (2011), p. 21, Figure 10.

\section{SHADOW ECONOMY AND UNEMPLOYMENT ${ }^{43}$}

Although there has been some discussion on the size of the shadow economy labor force and on its reasons, comparatively little attention has been given to the relationship between unemployment and working in the shadow economy. As Tanzi (1999) points out, "the current literature does not cast much light on these relationships even though the existence of large un-

43. This part is taken from Feld and Schneider (2010). 
derground activities would imply that one should look more deeply at what is happening in the labor market" (p. 347). The objective of the paper by Bajada and Schneider (2009) is to examine the extent of participation in the shadow economy by the unemployed. Their paper has investigated the relationship between the unemployment rate and the shadow economy. Previous literature on this topic has suggested that the relationship between these two variables is ambiguous, predominantly because a heterogeneous group of people working in the shadow economy exists and there are also various cyclical forces at work, such that they produce a net effect that is weakly correlated with unemployment. In their paper they have provided a suggestion for disentangling these cyclical effects, so as to study the component of the shadow economy that is influenced directly by those who are unemployed. They refer to this effect as the 'substitution effect' which typically increases during declining periods of legitimate economic activity (and increasing unemployment). Equipped with this approach for measuring the 'substitution effect', they discover that a relationship exists between changes in the unemployment rate and shadow economy activity.

By examining the growth cycle characteristics of the 'substitution effect' component of the shadow economy Bajada and Schneider (2009) determine that the growth cycles are symmetric (in terms of steepness and deepness) and that changes in the unemployment rate, whether positive or negative, had similar impacts on changes in the substitution effect component. They suggest that the shadow economy is a source of financial support during periods of unemployment for those genuinely wanting to participate in the legitimate economy. Although this does not exclude the possibility that long-term unemployed may also be participating in the shadow economy, it would appear that short-term fluctuations in unemployment directly contribute to short-term fluctuations in the shadow economy.

When Bajada and Schneider consider the various unemployment support programs across 12 OECD countries, there appears to be no real systematic relationship between the generosity of the social security systems and the nature of short-term shadow economic activity by the unemployed. Even the various replacement rates across the OECD countries appear to have little consequence on the rate at which the unemployed take on and cut back shadow economy activity. There is however some evidence to suggest that extended duration spell in unemployment lasts anywhere between less than 3 months to approximately 9 months.

On the whole Bajada and Schneider argue that dealing with unemployment participation in the shadow economy as a way of correcting the inequity it generates, is best handled by more stringent monitoring of those receiving unemployment benefits rather than reducing replace- 
ment rates as a way of encouraging re-integration into the work force. A strategy of reducing replacement rates would not only fail to maintain adequate support for those experiencing financial hardship during periods of unemployment, it is likely to have little impact on reducing participation by the unemployed who are willing and able to engage in shadow economy activity.

\section{ADJUSTMENTS OF SHADOW ECONOMY MEASURES (VALUE ADDED) IN NATIONAL ACCOUNTS}

Due to the strong increase of the size and development of the shadow economy (in value added terms) a number of countries have undertaken adjustments of this non observed economy measures in their national accounts ${ }^{44}$. OECD (2011, p.14) has detected seven adjustment activities, which are included in some countries in their national accounts.

A1: A producer deliberately does not register to avoid tax and social security obligations.

A2: A producer deliberately does not register as a legal identity or as entrepreneur because he is involved in illegal activities.

A3: A producer is not required to register because he has no market output.

A4: A legal person not surveyed due to reasons such as business register is out of date or updating procedures are inequate.

A5: Registered entrepreneurs may not be surveyed due to the statistical office does not conduct a survey of registered entrepreneurs.

A6: Cross output is underreported and/or intermediate consumption is overstated.

A7: Data is either not complete or not collected or not directly collectable and/or data are incorrectly handled.

If one considers those countries, which do some adjustment, one amazing thing is, that big adjustment takes place in Italy between 14,8 and 16,7 \% and in Poland between 7,8 and 15,7 $\%$. The largest adjustment is taking place in Russia with $24,3 \%$ and the smallest one in the United States with $0,8 \%$. Table 6.1 clearly shows that those countries, which do some adjustment, their adjustment is vastly different compared to other countries. Hence, this leads to the problem, that for these countries starting from Australia and ending with the United States

\footnotetext{
${ }^{44}$ The following text closely follows OECD (2011) pages 11 and 12, Box 2. Also the Table is taken from there.
} 
the measures of the size and development of the shadow economy in percent of official GDP is biased, because a part of the shadow economy has been already considered. This is certainly a further difficulty when comparing the size and development of shadow economies between countries.

\section{CONCLUSIONS}

In my paper some of the most recent developments in research on the shadow economy and undeclared work in highly developed OECD, developing and transition countries are shown. Besides the figures of the illicit work force in the rural and non-rural sector some other measures of the shadow economy labor force, like unpaid family workers, own account workers, multiple job holders, etc. are presented. The studies based on the MIMIC approach also report strong effects of tax morale, but underline the higher importance of tax policies and state regulation to increase the shadow economy.

The discussion of the recent literature shows that economic opportunities for employees, the overall situation on the labor market, not least unemployment are crucial for an understanding of the dynamics of the shadow economy. Individuals look for ways to improve their economic situation and thus contribute productively to aggregate income of a country. This holds regardless of their being active in the official or the unofficial economy.

If I come back to the headline of my paper "The shadow economy and work in the shadow: What do we (not) know?", I clearly realize that we have some knowledge about the size and development of the shadow economy and the size and development of the shadow economy labor force. For developing countries, the shadow economy labor force has reached a remarkable size according to OECD (2009) estimates, which is, that in most developing countries the shadow economy labor force is higher than the official labor force. What we do not know are the exact motives, why people work in the shadow economy and what is their relation and feeling if a government undertakes reforms in order to bring them back into the official economy. Hence, much more micro studies are needed to obtain a more detailed knowledge about people's motivation to work either the shadow economy and/or in the official one. 
Table 6.1: Adjustment of non-observed economy in National Accounts, around 2000

\begin{tabular}{|c|c|c|c|c|c|c|c|c|}
\hline & \multicolumn{8}{|c|}{ Activities included } \\
\hline & $\begin{array}{l}\text { Size of non-observed } \\
\text { economy ( } \% \text { of GDP) }\end{array}$ & $\begin{array}{l}\text { A } 1 \\
\text { Non } \\
\text { registered } \\
\text { producers }\end{array}$ & $\begin{array}{l}\text { A } 2 \\
\text { Non } \\
\text { registered } \\
\text { identity of a } \\
\text { producer }\end{array}$ & $\begin{array}{l}\text { A } 3 \\
\text { No requirement } \\
\text { to register }\end{array}$ & $\begin{array}{l}\text { A } 4 \\
\text { Non registra- } \\
\text { tion due to old } \\
\text { state }\end{array}$ & $\begin{array}{lr}\text { A } 5 & \\
\text { Not } & \text { cap- } \\
\text { tured } & \text { by } \\
\text { the } & \text { stat. } \\
\text { office } & \\
\end{array}$ & $\begin{array}{l}\text { A } 6 \\
\text { Underreporting } \\
\text { Of output }\end{array}$ & $\begin{array}{l}\text { A } 7 \\
\text { Incorrect } \\
\text { data }\end{array}$ \\
\hline Australia & 1,3 & & & $\mathbf{X}$ & & & $\mathbf{X}$ & $\mathbf{X}$ \\
\hline Austria & 7,9 & $\mathbf{X}$ & & $\mathbf{X}$ & $\mathbf{X}$ & $\mathbf{X}$ & $\mathrm{X}$ & $\mathbf{X}$ \\
\hline Belgium & $3,0-4,0$ & $\mathbf{X}$ & & $\mathbf{X}$ & & & $\mathbf{X}$ & $\mathbf{X}$ \\
\hline Canada & Not stated & $\mathbf{X}$ & $\mathbf{X}$ & $\mathbf{X}$ & & & $\mathbf{X}$ & $\mathbf{X}$ \\
\hline Czech Rep. & $\begin{array}{c}4,6(E) ; 6,6(I) ; 9,3 \\
(O)\end{array}$ & $\mathbf{X}$ & $\mathbf{X}$ & $\mathbf{X}$ & $\mathbf{X}$ & $\mathbf{X}$ & $\mathbf{X}$ & $\mathbf{X}$ \\
\hline Estonia & 9,6 & $\mathbf{X}$ & $\mathbf{X}$ & & & & $\mathbf{X}$ & $\mathbf{X}$ \\
\hline Finland & Not stated & $\mathbf{X}$ & & $\mathbf{X}$ & & & $\mathbf{X}$ & \\
\hline Germany & Not stated & & & & & & & \\
\hline Hungary & 11,9 & $\mathbf{X}$ & $\mathbf{X}$ & $\mathbf{X}$ & & & $\mathbf{X}$ & $\mathbf{X}$ \\
\hline Ireland & 4,0 & & & $\mathbf{X}$ & $\mathbf{X}$ & & $\mathbf{X}$ & $\mathbf{X}$ \\
\hline Italy & 14,8(L); 16,7(U) & $\mathbf{X}$ & & $\mathbf{X}$ & $\mathbf{X}$ & $\mathbf{X}$ & $\mathbf{X}$ & \\
\hline Mexico & 12,1 & & $\mathbf{X}$ & $\mathbf{X}$ & & & & \\
\hline Netherlands & 1,0 & & & & & & $\mathbf{X}$ & $\mathbf{X}$ \\
\hline Norway & $2,4(0) ; 1(E)$ & & & $\mathbf{X}$ & $\mathbf{X}$ & $\mathbf{X}$ & $\mathbf{X}$ & $\mathbf{X}$ \\
\hline Poland & $15,7(0) ; 7,8(E)$ & $\mathbf{X}$ & $\mathbf{X}$ & $\mathbf{X}$ & & & $\mathbf{X}$ & $\mathbf{X}$ \\
\hline Russia & 24,3 & $\mathbf{X}$ & & $\mathbf{X}$ & $\mathbf{X}$ & $\mathbf{X}$ & $\mathbf{X}$ & $\mathbf{X}$ \\
\hline Spain & 11,2 & $\mathbf{X}$ & & & $\mathbf{X}$ & & $\mathbf{X}$ & $\mathbf{X}$ \\
\hline Sweden & 1,3 & & $\mathbf{X}$ & & & & $\mathbf{X}$ & $\mathbf{X}$ \\
\hline Turkey & 1,66 & $\mathbf{X}$ & & $\mathbf{X}$ & & & $\mathbf{X}$ & \\
\hline UK & Not stated & $\mathbf{X}$ & & $\mathbf{X}$ & & $\mathbf{X}$ & $X$ & $X$ \\
\hline US & 0,8 & & & & & & $\mathbf{X}$ & \\
\hline
\end{tabular}

$\mathrm{O}=$ according to output approach; E-according to expenditure approach; I=according to income approach; L=Lower bound; U=Upper bound; Source: United Nations, UN, 2008, quoted from OECD (2011), p. 12, Table 2.1. 


\section{Appendix}

Table 1A: Size and Development of the Shadow Economy of 162 Countries

\begin{tabular}{|c|c|c|c|c|c|c|c|c|c|c|c|}
\hline \multirow[b]{2}{*}{ No. } & \multirow[b]{2}{*}{ Country } & \multicolumn{9}{|c|}{ Years } & \multirow{2}{*}{$\begin{array}{l}\text { Country } \\
\text { Average }\end{array}$} \\
\hline & & 1999 & 2000 & 2001 & 2002 & 2003 & 2004 & 2005 & 2006 & 2007 & \\
\hline 1 & Albania & 35.7 & 35.3 & 34.9 & 34.7 & 34.4 & 33.9 & 33.7 & 33.3 & 32.9 & 34.3 \\
\hline 2 & Algeria & 34.2 & 34.1 & 33.8 & 33.3 & 32.5 & 31.7 & 31.1 & 31.0 & 31.2 & 32.5 \\
\hline 3 & Angola & 48.8 & 48.8 & 48.4 & 47.4 & 47.3 & 47.1 & 45.0 & 44.0 & 42.1 & 46.5 \\
\hline 4 & Argentina & 25.2 & 25.4 & 26.1 & 27.6 & 26.4 & 25.5 & 24.7 & 23.8 & 23.0 & 25.3 \\
\hline 5 & Armenia & 46.6 & 46.3 & 45.4 & 44.5 & 43.9 & 43.6 & 42.7 & 42.1 & 41.1 & 44.0 \\
\hline 6 & Australia & 14.4 & 14.3 & 14.3 & 14.1 & 13.9 & 13.7 & 13.7 & 13.7 & 13.5 & 14.0 \\
\hline 7 & Austria & 10.0 & 9.8 & 9.7 & 9.8 & 9.8 & 9.8 & 9.8 & 9.6 & 9.5 & 9.8 \\
\hline 8 & Azerbaijan & 61.0 & 60.6 & 60.3 & 60.0 & 59.1 & 58.6 & 56.7 & 54.0 & 52.0 & 58.0 \\
\hline 9 & Bahamas, The & 26.3 & 26.2 & 26.4 & 26.5 & 27.0 & 27.4 & 26.7 & 26.2 & 26.2 & 26.5 \\
\hline 10 & Bahrain & 18.6 & 18.4 & 18.2 & 18.0 & 17.8 & 17.4 & \begin{tabular}{|l|}
17.1 \\
\end{tabular} & - & - & 17.9 \\
\hline 11 & Bangladesh & 36.0 & 35.6 & 35.5 & 35.7 & 35.6 & 35.5 & 35.1 & 34.5 & 34.1 & 35.3 \\
\hline 12 & Belarus & 48.3 & 48.1 & 47.9 & 47.6 & 47.0 & 46.1 & 45.2 & 44.2 & 43.3 & 46.4 \\
\hline 13 & Belgium & 22.7 & 22.2 & 22.1 & 22.0 & 22.0 & 21.8 & 21.8 & 21.4 & 21.3 & 21.9 \\
\hline 14 & Belize & 45.2 & 43.8 & 43.3 & 43.4 & 42.3 & 42.0 & 42.1 & 41.7 & 42.0 & 42.9 \\
\hline 15 & Benin & 51.2 & 50.2 & 49.8 & 49.6 & 49.3 & 49.5 & 49.8 & 49.6 & 49.1 & 49.8 \\
\hline 16 & Bhutan & 29.6 & 29.4 & 29.2 & 29.1 & 28.7 & 28.7 & 28.3 & 28.2 & 27.7 & 28.8 \\
\hline 17 & Bolivia & 67.0 & 67.1 & 67.6 & 67.7 & 67.7 & 66.9 & 64.3 & 62.8 & 63.5 & 66.1 \\
\hline 18 & $\begin{array}{l}\text { Bosnia \& Herze- } \\
\text { govina }\end{array}$ & 34.3 & 34.1 & 34.0 & 33.9 & 33.5 & 33.6 & 33.2 & 32.9 & 32.8 & 33.6 \\
\hline 19 & Botswana & 33.9 & 33.4 & 33.2 & 33.3 & 33.0 & 32.8 & 32.7 & 32.3 & 31.9 & 32.9 \\
\hline 20 & Brazil & 40.8 & 39.8 & 39.9 & 39.9 & 39.6 & 38.6 & 38.4 & 37.8 & 36.6 & 39.0 \\
\hline 21 & $\begin{array}{l}\text { Brunei Darussa- } \\
\text { lam }\end{array}$ & 31.3 & 31.1 & 31.0 & 30.2 & 29.9 & 31.2 & 31.8 & 30.8 & 31.2 & 30.9 \\
\hline 22 & Bulgaria & 37.3 & 36.9 & 36.6 & 36.1 & 35.6 & 34.9 & 34.1 & 33.5 & 32.7 & 35.3 \\
\hline 23 & Burkina Faso & 41.3 & 41.4 & 41.3 & 41.4 & 40.3 & 40.1 & 39.7 & 39.7 & 39.6 & 40.5 \\
\hline 24 & Burundi & 39.1 & 39.5 & 39.6 & 39.4 & 39.6 & 39.6 & 39.7 & 39.6 & 39.6 & 39.5 \\
\hline 25 & Cambodia & 50.4 & 50.1 & 49.6 & 50.0 & 49.2 & 48.8 & 47.8 & 46.8 & 46.0 & 48.7 \\
\hline 26 & Cameroon & 33.3 & 32.8 & 32.4 & 32.1 & 31.7 & 31.6 & 31.6 & 31.4 & 31.4 & 32.0 \\
\hline 27 & Canada & 16.3 & 16.0 & 15.9 & 15.8 & 15.7 & 15.6 & 15.5 & 15.3 & 15.3 & 15.7 \\
\hline 28 & Cape Verde & 36.5 & 36.1 & 35.9 & 35.9 & 35.7 & 35.8 & 35.4 & 34.1 & 33.4 & 35.4 \\
\hline 29 & $\begin{array}{l}\text { Central African } \\
\text { Republic }\end{array}$ & 42.8 & 42.6 & 43.1 & 44.0 & 46.9 & 47.3 & 46.9 & 45.9 & 45.1 & 45.0 \\
\hline 30 & Chad & 45.8 & 46.2 & 45.5 & 45.1 & 44.2 & 41.5 & 41.1 & 41.7 & 42.2 & 43.7 \\
\hline 31 & Chile & 19.9 & 19.8 & 19.6 & 19.6 & 19.4 & 19.1 & 18.9 & 18.7 & 18.5 & 19.3 \\
\hline 32 & China & 13.2 & 13.1 & 13.0 & 12.9 & 12.8 & 12.6 & 12.5 & 12.2 & 11.9 & 12.7 \\
\hline 33 & Coloml & 39.4 & 39.1 & 38.9 & 38.9 & 37.9 & 37.1 & 36.1 & 35.1 & 33.5 & 37.3 \\
\hline 34 & Comoros & 39.3 & 39.6 & 39.0 & 37.7 & 37.6 & 39.0 & 38.0 & 38.4 & 39.4 & 38.7 \\
\hline 35 & Congo, Dem. Rep. & 47.2 & 48.0 & 48.2 & 48.1 & 47.1 & 46.9 & 46.8 & 46.8 & 46.7 & 47.3 \\
\hline 36 & Congo, Rep. & 49.5 & 48.2 & 47.2 & 46.8 & 46.8 & 46.2 & 44.7 & 43.3 & 44.6 & 46.4 \\
\hline 37 & Costa Rica & 26.1 & 26.2 & 26.4 & 26.4 & 26.1 & 25.9 & 25.6 & 25.0 & 24.0 & 25.7 \\
\hline 38 & Côte d'Ivoire & 41.4 & 43.2 & 44.3 & 45.5 & 46.0 & 46.1 & 46.3 & 46.8 & 47.0 & 45.2 \\
\hline 39 & Croatia & 33.8 & 33.4 & 33.2 & 32.6 & 32.1 & 31.7 & 31.3 & 30.8 & 30.4 & 32.1 \\
\hline
\end{tabular}


Table 1A: Size and Development of the Shadow Economy of 162 Countries (cont.)

\begin{tabular}{|c|c|c|c|c|c|c|c|c|c|c|c|}
\hline \multirow[b]{2}{*}{ No. } & \multirow[b]{2}{*}{ Country } & \multicolumn{9}{|c|}{ Years } & \multirow{2}{*}{$\begin{array}{l}\text { Country } \\
\text { Average }\end{array}$} \\
\hline & & 1999 & 2000 & 2001 & 2002 & 2003 & 2004 & 2005 & 2006 & 2007 & \\
\hline 40 & Cyprus & 29.2 & 28.7 & 28.2 & 27.8 & 28.2 & 28.1 & 27.7 & 27.3 & 26.5 & 28.0 \\
\hline 41 & Czech Republic & 19.3 & 19.1 & 18.9 & 18.8 & 18.7 & 18.4 & 17.8 & 17.3 & 17.0 & 18.4 \\
\hline 42 & Denmark & 18.4 & 18.0 & 18.0 & 18.0 & 18.0 & 17.8 & 17.6 & 17.0 & 16.9 & 17.7 \\
\hline 43 & $\begin{array}{l}\text { Dominican Re- } \\
\text { public }\end{array}$ & 32.4 & 32.1 & 32.4 & 32.1 & 32.1 & 32.4 & 31.7 & 31.0 & 30.5 & 31.9 \\
\hline 44 & Ecuador & 34.2 & 34.4 & 33.7 & 33.3 & 32.8 & 31.6 & 30.8 & 30.4 & 30.4 & 32.4 \\
\hline 45 & Egypt, Arab Rep. & 35.5 & 35.1 & 35.2 & 35.7 & 35.4 & 35.0 & 34.8 & 34.1 & 33.1 & 34.9 \\
\hline 46 & El Salvador & 46.5 & 46.3 & 46.2 & 45.6 & 45.2 & 44.9 & 44.5 & 43.8 & 43.0 & 45.1 \\
\hline 47 & Equatorial Guinea & 32.7 & 32.8 & 32.0 & 31.5 & 31.2 & 30.8 & 30.5 & 30.6 & 30.1 & 31.4 \\
\hline 48 & Eritrea & 38.1 & 40.3 & 39.4 & 39.4 & 40.3 & 40.6 & 40.5 & 41.2 & 41.4 & 40.1 \\
\hline 49 & 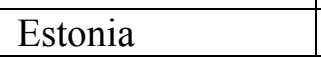 & - & 32.7 & 32.4 & 32.0 & 31.4 & 31.1 & 30.5 & 29.8 & 29.5 & 31.2 \\
\hline 50 & & 40.6 & 40.3 & 39.5 & 39.6 & 40.1 & 38.6 & 37.7 & 36.3 & 35.1 & 38.6 \\
\hline 51 & Fiji & 32.9 & 33.6 & 33.3 & 32.6 & 32.5 & 31.9 & \begin{tabular}{|l|l}
31.4 \\
\end{tabular} & 31.0 & 32.6 & 32.4 \\
\hline 52 & 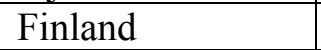 & 18.4 & 18.1 & 17.9 & 17.8 & \begin{tabular}{|l|l}
17.7 \\
\end{tabular} & 17.6 & 17.4 & 17.1 & 17.0 & .7 \\
\hline 53 & & 15.7 & 15.2 & 15.0 & 15.1 & 15.0 & 14.9 & 14.8 & 14.8 & 14.7 & 5.0 \\
\hline 54 & 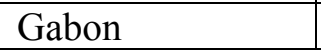 & 46.2 & 48.0 & 47.4 & 47.6 & 47.5 & 48.0 & 47.7 & 48.0 & 47.3 & 47.5 \\
\hline 55 & & 6.1 & 45.1 & \begin{tabular}{|l|l}
4.7 \\
\end{tabular} & 47.1 & 45.4 & 43.8 & 43.6 & 42.4 & 40.9 & 44.3 \\
\hline 56 & & 8.3 & 67.3 & 67.2 & 67.2 & 65.9 & 65.5 & 65.1 & 63.6 & 62.1 & 65.8 \\
\hline 57 & 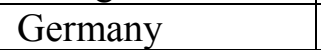 & 16.4 & 16.0 & 15.9 & 16.1 & 16.3 & $\mid 16.1$ & 16.0 & 15.6 & 15.3 & 16.0 \\
\hline 58 & & 2.0 & 41.9 & 41.8 & 41.6 & 41.3 & 40.9 & 39.5 & 38.6 & 38.3 & 40.7 \\
\hline 59 & & 8.5 & 28.7 & 28.2 & 28.0 & 27.4 & 27.1 & 26.9 & 26.4 & 26.5 & 27.5 \\
\hline 60 & $\mathrm{Gu}$ & 51.6 & 51.5 & 51.6 & 51.2 & 50.7 & 50.5 & 50.2 & 49.0 & 47.9 & 50.5 \\
\hline 61 & & 39.7 & 39.6 & 39.3 & 38.7 & 38.8 & 38.5 & 38.4 & 38.9 & 39.2 & 39.0 \\
\hline 62 & & 40.4 & 39.6 & 39.6 & 40.7 & 41.5 & 41.9 & 41.7 & 41.5 & 41.6 & 40.9 \\
\hline 63 & $\mathrm{Gl}$ & 33.4 & 33.6 & 33.3 & 33.7 & 33.9 & 33.4 & 34.3 & 33.8 & 34.0 & 33.7 \\
\hline 64 & & 54.8 & 55.4 & 56.1 & 56.5 & \begin{tabular}{|l|l|}
56.4 \\
\end{tabular} & 57.4 & 57.1 & 57.0 & 57.1 & 56.4 \\
\hline 65 & $\mathrm{H}$ & 50.3 & 49.6 & 49.7 & 49.6 & \begin{tabular}{|l}
48.9 \\
\end{tabular} & 48.3 & 47.3 & 46.1 & 45.1 & 48.3 \\
\hline 66 & & 17.0 & 16.6 & 16.6 & 16.6 & \begin{tabular}{|l|l}
16.4 \\
\end{tabular} & \begin{tabular}{|l|}
15.9 \\
\end{tabular} & 15.5 & 15.0 & 14.7 & 16.0 \\
\hline 67 & $\mathrm{Hy}$ & 25.4 & 25.1 & 24.8 & 24.5 & 24.4 & 24.1 & 24.0 & 23.7 & 23.7 & 24.4 \\
\hline 68 & & 16.0 & 15.9 & 15.8 & 16.0 & \begin{tabular}{|l|}
15.9 \\
\end{tabular} & 15.5 & 15.1 & 15.0 & 15.0 & 15.6 \\
\hline 69 & & 23.2 & 23.1 & 22.8 & 22.6 & 22.3 & 22.0 & 21.7 & 21.2 & 20.7 & 22.2 \\
\hline 70 & - & 19.7 & 19.4 & 19.4 & 19.3 & 19.1 & 18.8 & 18.6 & 18.3 & 17.9 & 18.9 \\
\hline 71 & & 19.1 & 18.9 & 19.0 & 18.7 & 18.2 & 17.9 & 18.1 & 17.7 & 17.3 & 18.3 \\
\hline 72 & & 16.1 & 15.9 & 15.9 & 15.9 & \begin{tabular}{|l|l}
16.0 \\
\end{tabular} & 15.8 & 15.6 & 15.5 & 15.4 & 15.8 \\
\hline 73 & Isra & 22.7 & 21.9 & 22.3 & 22.7 & 22.7 & 22.1 & 21.8 & 21.2 & 20.7 & 22.0 \\
\hline 74 & & 27.8 & 27.1 & 26.7 & 26.8 & 27.0 & 27.0 & 27.1 & 26.9 & 26.8 & 27.0 \\
\hline 75 & Jan & 36.4 & 36.4 & 36.2 & 36.2 & \begin{tabular}{|l|l}
34.4 \\
\end{tabular} & 33.9 & 34.0 & 32.9 & 32.5 & 34.8 \\
\hline 76 & Japan & 11.4 & 11.2 & 11.2 & 11.3 & 11.2 & 10.9 & 10.7 & 10.4 & 10.3 & 11.0 \\
\hline 77 & & 19.4 & 19.4 & 19.2 & 18.9 & 18.7 & 18.3 & 18.0 & 17.5 & 17.2 & 18.5 \\
\hline 78 & Kazakh & 43.8 & 43.2 & 42.5 & 42.0 & 41.1 & 40.6 & 39.8 & 38.9 & 38.4 & 41.1 \\
\hline 79 & Kenya & 33.7 & 34.3 & 34.0 & 34.8 & 34.6 & 33.7 & 32.7 & 31.1 & 29.5 & 33.2 \\
\hline 80 & Korea, R & 28.3 & 27.5 & 27.3 & 26.9 & 26.8 & 26.5 & 26.3 & 25.9 & 25.6 & 26.8 \\
\hline 81 & Kuwait & 20.1 & 20.1 & 20.2 & 20.3 & 19.3 & 18.8 & 18.1 & 17.9 & - & 19.4 \\
\hline 82 & Kyrgyz & 41.4 & 41.2 & 40.8 & 41.4 & 40.5 & 39.8 & 40.1 & 39.8 & 38.8 & 40.4 \\
\hline 83 & Lao PDR & 30.9 & 30.6 & 30.2 & 30.0 & 29.8 & 29.4 & 28.9 & 28.4 & 28.0 & 29.6 \\
\hline
\end{tabular}


Table 1A: Size and Development of the Shadow Economy of 162 Countries (cont.)

\begin{tabular}{|c|c|c|c|c|c|c|c|c|c|c|c|}
\hline \multirow[b]{2}{*}{ No. } & \multirow[b]{2}{*}{ Country } & \multicolumn{9}{|c|}{ Year } & \multirow{2}{*}{$\begin{array}{l}\text { Country } \\
\text { Average }\end{array}$} \\
\hline & & 1999 & 2000 & 2001 & 2002 & 2003 & 2004 & 2005 & 2006 & 2007 & \\
\hline 84 & Latvia & 30.8 & 30.5 & 30.1 & 29.8 & 29.4 & 29.0 & 28.4 & 27.7 & 27.2 & 29.2 \\
\hline 85 & Lebanon & 34.1 & 34.1 & 33.7 & 33.5 & 33.2 & 32.4 & 32.4 & 32.8 & 32.0 & 33.1 \\
\hline 86 & Lesotho & 31.7 & 31.3 & 31.1 & 31.0 & 30.7 & 30.1 & 30.2 & 29.3 & 28.8 & 30.5 \\
\hline 87 & Liberia & 44.2 & 43.2 & 43.2 & 43.1 & 45.0 & 45.4 & 44.9 & 44.5 & 44.2 & 44.2 \\
\hline 88 & Libya & 34.7 & 35.1 & 34.5 & 33.8 & 34.9 & 33.9 & 33.1 & 32.0 & 30.9 & 33.7 \\
\hline 89 & Lithuania & 33.8 & 33.7 & 33.3 & 32.8 & 32.0 & 31.7 & 31.0 & 30.4 & 29.7 & 32.0 \\
\hline 90 & Luxembourg & 10.0 & 9.8 & 9.8 & 9.8 & 9.8 & 9.8 & 9.7 & 9.6 & 9.4 & 9.7 \\
\hline 91 & Macao, China & 13.3 & 13.1 & 13.0 & 12.9 & 12.5 & 12.1 & 11.9 & 11.7 & 11.1 & 12.4 \\
\hline 92 & Macedonia & 39.0 & 38.2 & 39.1 & 38.9 & 38.4 & 37.4 & 36.9 & 36.0 & 34.9 & 37.6 \\
\hline 93 & Madag & 40.1 & 39.6 & 38.7 & 44.8 & 43.4 & 41.6 & 40.8 & 39.8 & 38.5 & 40.8 \\
\hline 94 & Malawi & 39.9 & 40.3 & 42.5 & 44.4 & 43.4 & 42.5 & 42.6 & 41.3 & 39.4 & 41.8 \\
\hline 95 & Mal & 32.2 & 31.1 & 31.6 & 31.5 & 31.2 & 30.7 & 30.4 & 30.0 & 29.6 & 30.9 \\
\hline 96 & Malc & 30.3 & 30.3 & 30.0 & 29.4 & 29.2 & 28.9 & 29.6 & 29.3 & 28.6 & 29.5 \\
\hline 97 & Mali & 42.5 & 42.3 & 40.8 & 40.2 & 39.9 & 40.6 & 40.1 & 39.9 & 39.9 & 40.7 \\
\hline 98 & Malta & 27.4 & 27.1 & 27.3 & 27.3 & 27.5 & 27.6 & 27.3 & 27.0 & 26.5 & 27.2 \\
\hline 99 & Maurit & 35.5 & 36.1 & 36.0 & 35.8 & 35.8 & 35.1 & 34.4 & 31.7 & & 35.1 \\
\hline 100 & Mau & 23.3 & 23.1 & 22.9 & 23.0 & 22.7 & 22.4 & 22.4 & 22.2 & 21.9 & 22.7 \\
\hline 101 & $\mathrm{Me}$ & 30.8 & 30.1 & 30.3 & 30.4 & 30.5 & 30.1 & 29.9 & 29.2 & 28.8 & 30.0 \\
\hline 102 & Moldova & 45.6 & 45.1 & 44.1 & 44.5 & 44.6 & 44.0 & 43.4 & 44.3 & - & 44.5 \\
\hline 103 & Mongolia & 18.4 & 18.4 & 18.3 & 18.0 & $\mid 17.7$ & 17.4 & \begin{tabular}{|l|}
17.1 \\
\end{tabular} & $\mid 16.7$ & 16.4 & 17.6 \\
\hline 104 & Mor & 36.5 & 36.4 & 35.7 & 35.5 & 35.0 & 34.2 & 34.9 & 33.1 & 33.1 & 34.9 \\
\hline 105 & $\mathrm{Mo}$ & 41.1 & 40.3 & 40.4 & 39.8 & \begin{tabular}{|l|}
39.8 \\
\end{tabular} & 39.7 & 38.9 & 38.6 & - & 39.8 \\
\hline 106 & Mya & 51.6 & 52.6 & 51.5 & 50.7 & 49.0 & 49.1 & 47.8 & - & - & 50.3 \\
\hline 107 & Nami & 31.4 & 31.4 & 31.2 & 31.3 & 30.7 & 29.7 & 29.6 & 28.8 & 28.5 & 30.3 \\
\hline 108 & $\mathrm{Ne}$ & 37.2 & 36.8 & 36.7 & 37.1 & 36.9 & 36.8 & 36.7 & 36.3 & 36.0 & 36.7 \\
\hline 109 & Netherlands & 13.3 & 13.1 & 13.1 & 13.2 & 13.3 & 13.2 & 13.2 & 13.2 & 13.0 & 13.2 \\
\hline 110 & $\mathrm{Ner}$ & 13.0 & 12.8 & 12.6 & 12.4 & 12.2 & 12.0 & 12.1 & 12.1 & 12.0 & 12.4 \\
\hline 111 & & 45.7 & 45.2 & 45.3 & 45.5 & 45.0 & 44.2 & 43.8 & 43.5 & 43.1 & 44.6 \\
\hline 112 & Niger & 41.7 & 41.9 & 40.9 & 40.3 & 39.7 & 40.7 & 39.7 & 38.6 & - & 40.4 \\
\hline 113 & Nig & 58.0 & 57.9 & 57.8 & 57.6 & 56.3 & 55.1 & 53.8 & 53.0 & - & 56.2 \\
\hline 114 & Norway & 19.2 & 19.1 & 19.0 & 19.0 & 19.0 & 18.5 & 18.5 & 18.2 & 18.0 & 18.7 \\
\hline 115 & $\mathrm{Om}$ & 19.1 & 18.9 & 18.5 & 18.5 & \begin{tabular}{|l|}
18.4 \\
\end{tabular} & 18.3 & 18.0 & 17.6 & - & 18.4 \\
\hline 116 & Pak & 37.0 & 36.8 & 37.0 & 36.8 & 36.2 & 35.3 & 34.9 & 33.8 & 33.6 & 35.7 \\
\hline 117 & Panama & 64.8 & 64.1 & 64.7 & 65.1 & 64.4 & 63.5 & 61.7 & 60.0 & - & 63.5 \\
\hline 118 & $\begin{array}{l}\text { Papua } \mathrm{Ne} \\
\text { nea }\end{array}$ & 35.5 & 36.1 & 36.8 & 37.1 & 37.1 & 37.0 & 37.2 & 37.1 & 36.5 & 36.7 \\
\hline 119 & Paraguay & 38.0 & 39.8 & 39.7 & 40.1 & 39.1 & 38.3 & 38.2 & 37.4 & - & 38.8 \\
\hline 120 & Peru & 60.1 & 59.9 & 60.2 & 59.1 & 58.6 & 57.9 & 57.2 & 55.7 & 53.7 & 58.0 \\
\hline 121 & Philippir & 43.8 & 43.3 & 43.0 & 42.5 & 42.0 & 41.6 & 40.1 & 39.5 & 38.3 & 41.6 \\
\hline 122 & Poland & 27.7 & 27.6 & 27.7 & 27.7 & 27.5 & 27.3 & 26.9 & 26.4 & 26.0 & 27.2 \\
\hline 123 & Portugal & 23.0 & 22.7 & 22.6 & 22.7 & 23.0 & 23.1 & 23.3 & 23.2 & 23.0 & 23.0 \\
\hline 124 & Quatar & - & 19.0 & 19.3 & 19.0 & 19.6 & 17.4 & 18.4 & - & - & 14.1 \\
\hline 125 & Romania & 34.3 & 34.4 & 33.7 & 33.5 & 32.8 & 32.0 & 31.7 & 30.7 & 30.2 & 32.6 \\
\hline 126 & $\begin{array}{l}\text { Russian Federati- } \\
\text { on }\end{array}$ & 47.0 & 46.1 & 45.3 & 44.5 & 43.6 & 43.0 & 42.4 & 41.7 & 40.6 & 43.8 \\
\hline 127 & Rwanda & 40.5 & 40.3 & 40.6 & 39.9 & 40.7 & 40.2 & 39.3 & 39.1 & - & 40.1 \\
\hline
\end{tabular}


Table 1A: Size and Development of the Shadow Economy of 162 Countries (cont.)

\begin{tabular}{|c|c|c|c|c|c|c|c|c|c|c|c|}
\hline \multirow[b]{2}{*}{ No. } & \multirow[b]{2}{*}{ Country } & \multicolumn{9}{|c|}{ Year } & \multirow{2}{*}{$\begin{array}{l}\text { Country } \\
\text { Average }\end{array}$} \\
\hline & & 1999 & 2000 & 2001 & 2002 & 2003 & 2004 & 2005 & 2006 & 2007 & \\
\hline 128 & Saudi Arabia & 18.7 & 18.4 & 18.7 & 19.2 & 18.3 & 17.7 & 17.4 & 17.4 & 16.8 & 18.1 \\
\hline 129 & Senegal & 45.0 & 45.1 & 44.5 & 45.1 & 44.4 & 43.2 & 42.3 & 42.4 & 41.7 & 43.7 \\
\hline 130 & Sierra Leone & 48.6 & 48.6 & 47.6 & 45.4 & 44.8 & 44.4 & 44.3 & 43.6 & 42.9 & 45.6 \\
\hline 131 & Singapore & 13.3 & 13.1 & 13.3 & 13.3 & 13.1 & 12.8 & 12.7 & 12.4 & 12.2 & 12.9 \\
\hline 132 & Slovak Republic & 18.9 & 18.9 & 18.8 & 18.6 & 18.3 & 18.1 & 17.6 & 17.2 & 16.8 & 18.1 \\
\hline 133 & Slovenia & 27.3 & 27.1 & 26.7 & 26.6 & 26.4 & 26.2 & 25.8 & 25.3 & 24.7 & 26.2 \\
\hline 134 & Solomon Islands & 31.7 & 33.4 & 34.5 & 34.8 & 34.7 & 33.8 & 33.4 & 33.2 & 32.7 & 33.6 \\
\hline 135 & South Africa & 28.4 & 28.4 & 28.4 & 28.0 & 27.8 & 27.1 & 26.5 & 26.0 & 25.2 & 27.3 \\
\hline 136 & Spain & 23.0 & 22.7 & 22.4 & 22.4 & 22.4 & 22.5 & 22.4 & 22.4 & 22.2 & 22.5 \\
\hline 137 & Sri Lar & 45.2 & 44.6 & 44.6 & 44.1 & 43.8 & 43.9 & 43.4 & 42.9 & 42.2 & 43.9 \\
\hline 138 & Sudan & 34.1 & - & - & - & - & - & - & - & - & 34.1 \\
\hline 139 & Sur & 39.7 & 39.8 & 39.3 & 38.9 & 38.1 & 36.9 & 36.5 & 35.9 & 35.1 & 37.8 \\
\hline 140 & Swaz & 43.5 & 41.4 & 41.3 & 40.9 & 40.2 & 40.1 & 39.3 & 38.9 & - & 40.7 \\
\hline 141 & Swe & 19.6 & 19.2 & 19.1 & 19.0 & 18.7 & 18.5 & 18.6 & 18.2 & 17.9 & 18.8 \\
\hline 142 & rland & 8.8 & 8.6 & 8.6 & 8.6 & 8.8 & 8.6 & 8.5 & 8.3 & 8.1 & 8.5 \\
\hline 143 & $\begin{array}{l}\text { Syrian Arab Re- } \\
\text { public }\end{array}$ & 19.3 & 19.3 & 19.2 & 19.1 & 19.3 & 19.1 & 19.0 & 18.7 & 18.5 & 19.1 \\
\hline 144 & Taiwan & 25.7 & 25.4 & 25.7 & 25.4 & 25.2 & 24.7 & 24.5 & 24.2 & 23.9 & 25.0 \\
\hline 145 & Taj & 43.5 & 43.2 & 42.9 & 42.7 & 42.1 & 41.7 & 41.5 & 41.2 & 41.0 & 42.2 \\
\hline 146 & Tal & 58.6 & 58.3 & 57.7 & 56.9 & 56.6 & 56.0 & 55.4 & 54.7 & 53.7 & 56.4 \\
\hline 147 & Thail & 53.4 & 52.6 & 52.4 & 51.5 & 50.2 & 49.6 & 49.0 & 48.5 & 48.2 & 50.6 \\
\hline 148 & Togo & 34.4 & 35.1 & 35.4 & 34.5 & 34.9 & 35.0 & 35.0 & 34.6 & - & 34.9 \\
\hline 149 & $\begin{array}{l}\text { Trinidad and To- } \\
\text { bago }\end{array}$ & 34.7 & 34.4 & 34.3 & 34.4 & 33.4 & 33.1 & 32.9 & 31.9 & 31.5 & 33.4 \\
\hline 150 & Tun & 38.7 & 38.4 & 37.8 & 37.8 & 37.4 & 36.9 & 36.7 & 35.9 & 35.4 & 37.2 \\
\hline 151 & Tur & 32.7 & 32.1 & 32.8 & 32.4 & 31.8 & 31.0 & 30.0 & 29.5 & 29.1 & 31.3 \\
\hline 152 & Uganda & 43.5 & 43.1 & 42.9 & 42.9 & 42.5 & 42.4 & 42.2 & 41.0 & 40.3 & 42.3 \\
\hline 153 & Ukraine & 52.7 & 52.2 & 51.4 & 50.8 & 49.7 & 48.8 & 47.8 & 47.3 & 46.8 & 49.7 \\
\hline 154 & $\begin{array}{l}\text { United Arab Emi- } \\
\text { rates }\end{array}$ & 26.3 & 26.4 & 27.0 & 27.4 & 26.3 & 25.4 & 24.8 & 23.5 & - & 25.9 \\
\hline 155 & United Kingdom & 12.8 & 12.7 & 12.6 & 12.6 & 12.5 & 12.4 & 12.4 & 12.3 & 12.2 & 12.5 \\
\hline 156 & United States & 8.8 & 8.7 & 8.8 & 8.8 & 8.7 & 8.6 & 8.5 & 8.4 & 8.4 & 8.6 \\
\hline 157 & Uruguay & 50.5 & 51.1 & 51.7 & 54.0 & 53.6 & 51.1 & 49.2 & 48.5 & 46.1 & 50.6 \\
\hline 158 & Venezuela, RB & 33.8 & 33.6 & 33.5 & 35.5 & 36.9 & 34.9 & 33.5 & 32.0 & 30.9 & 33.8 \\
\hline 159 & Vietnam & 15.8 & 15.6 & 15.5 & 15.3 & 15.2 & 15.1 & 14.7 & 14.6 & 14.4 & 15.1 \\
\hline 160 & Yemen, Rep. & 27.7 & 27.4 & 27.3 & 27.2 & 27.0 & 27.0 & 26.6 & 26.8 & 26.8 & 27.1 \\
\hline 161 & Zambia & 49.3 & 48.9 & 48.3 & 48.1 & 47.5 & 46.8 & 46.3 & 45.0 & 43.9 & 47.1 \\
\hline 162 & Zimbabwe & 59.6 & 59.4 & 61.5 & 62.8 & 63.7 & 62.3 & 62.0 & 62.3 & 62.7 & 61.8 \\
\hline & Time Average & 34.0 & 33.7 & 33.6 & 33.6 & 33.3 & 32.9 & 32.5 & 32.1 & 31.2 & \\
\hline
\end{tabular}




\section{REFERENCES}

Alderslade, J., J. Talmage and Y. Freeman (2006), Measuring the Informal Economy: One Neighborhood at a Time, Discussion Paper, The Brooking Institution Metropolitan Policy Program, Washington D.C., September 2006.

Allingham, M.G. and A. Sandmo (1972), Income Tax Evasion: A Theoretical Analysis, Journal of Public Economics 1/3, pp. 323-338.

Andreoni, J., B. Erard and J. Feinstein (1998), Tax Compliance, Journal of Economic Literature 36/4, pp. $818-860$.

Bajada, C. and F. Schneider (2009), Unemployment and the Shadow Economy in the OECD, Review Economique, 60/4, pp. 1011-1033Bartlett, B. (1998), Corruption, the Underground Economy, and Taxation, Unpublished Manuscript, National Center for Policy Analysis, Washington D.C.

Bhattacharyya, D.K. (1999), On the Economic Rationale of Estimating the Hidden Economy, Economic Journal 109/3, 348-359.

Blackwell, C. (2010), A Meta Analysis of Incentive Effects, Intex Compliance Experiments, in: J. Alm, J. Martinez-Vazquez and Benno Torgler (eds.), Developing alternative Framework explaining Tax Compliance, London: Routledge Publishing Company.

Breusch, T. (2005a), The Canadian Underground Economy: An Examination of Giles and Tedds, Canadian Tax Journal 53/4, 367-391.

Breusch, T. (2005b), Estimating the Underground Economy Using MIMIC Models, Working Paper, Canberra, Australia, http://econwpa.wustl.edu/eps/em/papers/0507/0507003.pdf.

Brueck, T., J.B. Haisten-DeNew and K.F. Zimmermann (2006), Creating Low-Skilled Jobs by Subsidizing Market Contracted Household Work, Applied Economics 38/4, 899-911.

Buehn, A., A. Karmann and F. Schneider (2009), Shadow Economy and Do-it-yourself Activities: The German Case, Journal of Institutional and Theoretical Economics, 165/4, pp.701-722.

Buehn, Andreas and Friedrich Schneider (2011), Corruption and the Shadow Economy: Like Oil and Vinegar, like Water and Fire?, International Tax and Public Finance, LLC, 2011, pp.220-241.

Cappiello, M.A. (1986), Proposita di bibliografia ragionata sull'economia sommersa nell'industria (Italia 1970-82), in: A. Bagnasco (ed.): L'altra metà dell'economia, La ricerca internazionale sull'economia informale, Liguori, Naples, 307-345.

Charmes, J. (2002), Informal Sector, Poverty and Gender: A Review of the Empirical Evidence, Paper prepared on behalf of Wiego (Women in Informal Employment: Globalizing and Organizing), OECD and World Bank, Washington and Paris, 2002.

Charmes, J. (2007), Informal Sector Poverty and Gender, A Review of Empirical Evidence, Paper prepared on behalf of Wiego (Women in Formal Employment Globalizing and Organizing), OECD and World Bank, Washington and Paris, 2007. 
Charmes, J. (2008), Informal Sector Poverty and Gender, A Review of Empirical Evidence, Paper prepared on behalf of Wiego (Women in Formal Employment Globalizing and Organizing), OECD and World Bank, Washington and Paris 2008.

Chen, M. (2004), Rethinking the Informal Economy: Linkages with the Formal Economy and the Formal Regulatory Environment, Paper presented a the EGDI-WIDR Conference 'Unleashing Human Potential: Linking the Informal and Formal Sectors, Helsinki, Finland, 2004.

Chickering, L.A. and M. Salahdine (eds.) (1991), The Silent Revolution - The Informal Sector in Five Asian and near Eastern Countries, An International Center for Economic Growth Publication (ICS Press), San Francisco.

Dallago, B. (1990), The Irregular Economy: The "Underground Economy" and the "Black Labor Market”, Publishing Company, Dartmouth (U.K.).

De Grazia, R. (1983), Le travail clandistin: Situation dans les pays industrialisés à économie de marché, Bit, Genève.

Dell'Anno R., (2003). Estimating the Shadow Economy in Italy: a Structural Equation Approach, Working Paper 2003-7, Department of Economics, University of Aarhus.

Dell'Anno, R. and F. Schneider (2003), The Shadow Economy of Italy and other OECD Countries: What Do We Know?, Journal of Public Finance and Public Choice 21, 223-245.

Dell'Anno, R. and F. Schneider (2009), A Complex Approach to Estimate Shadow Economy: The Structural Equation Modelling, in: M. Faggnini and T. Looks (eds.), Coping with the Complexity of Economics, Berlin: Springer, pp. 110-130.

Dixon, H. (1999), Controversy, On the Hidden Economy, Editorial introduction, Economic Journal 456/3, pp.335-337.

Dreher, A. and F. Schneider (2009) Corruption and the Shadow Economy: An Empirical Analysis, Public Choice, 144/2, pp.215-277.

Dreher, A., C. Kotsogiannis and S. McCorriston (2007), Corruption around the World: Evidence from a Structural Model, Journal of Comparative Economics 35/4, pp. 443-466.

Dreher, A., C. Kotsogiannis and S. McCorriston (2009), How Do Institutions Affect Corruption and the Shadow Economy?, International Tax and Public Finance, 16/4, pp.773-796.

Eck, R. van and B. Kazemier (1988), Features of the Hidden Economy in the Netherlands, Review of Income and Wealth 34/3, pp. 251-273.

Enste, D. and F. Schneider (2006), Umfang und Entwicklung der Schattenwirtschaft in 145 Ländern, in: F. Schneider and D. Enste (eds.), Jahrbuch Schattenwirtschaft 2006/07. Zum Spannungsfeld von Poltik und Ökonomie, LIT Verlag, Berlin, 55-80.

Feige, E.L. (ed.) (1989), The Underground Economies. Tax Evasion and Information Distortion, Cambridge University Press, Cambridge.

Feige, E.L. (1994), The Underground Economy and the Currency Enigma, Supplement to Public Finance/ Finances Publiques 49, 119-136. 
Feld, L.P. and B.S. Frey (2002a), Trust Breeds Trust: How Taxpayers are Treated, Economics of Governments 3, 87-99.

Feld, L.P. and B.S. Frey (2002b), The Tax Authority and the Taxpayer: An Exploratory Analysis. Discussion Paper, University of Zurich

Feld, L.P. and B.S. Frey (2007), Tax Compliance as the Result of a Psychological Tax Contract: The Role of Incentives and Responsive Regulation, Law and Policy 29/1, pp. 102-120.

Feld, L.P. and C. Larsen (2005), Black Activities in Germany in 2001 and 2004: A Comparison Based on Survey Data, Study No. 12, The Rockwool Foundation Research Unit, Copenhagen.

Feld, L.P. and C. Larsen (2008), "Black" Activities Low in Germany in 2006, News from the Rockwool Foundation Research Unit, March 2008, 1-12.

Feld, L.P. and C. Larsen (2009), Undeclared Work in Germany 2001-2007 - Impact of Deterrence, Tax Policy, and Social Norms: An Analysis Based on Survey Data, Springer, Berlin et al.

Feld, L.P. and F. Schneider (2010), Survey on the Shadow Economy and Undeclared Earnings in OECD Countries, German Economic Review 11/2, pp. 109-149.

Feld, L-P., A. Schmidt and F. Schneider (2007), Tax Evasion, Black Activities and Deterrence in Germany: An Institutional and Empirical Perspective, Discussion Paper, Department of Economics, University of Heidelberg, Germany.

Flaming, D., B. Hayolamak and P. Jossart (2005), Hopeful Workers, Marginal Jobs: LA's Off-TheBooks Labor Force, Economic Roundtable, Los Angeles, CA, 2005.

Fleming, M.H., Roman, J. and G. Farrel (2000), The Shadow Economy, Journal of International Affairs, Spring 2000, No. 53/2, 64-89.

Frey, B.S. (1997), Not just for the Money: An Economic Theory of Personal Motivation, Edward Elgar, Cheltenham.

Frey, B.S. and W. Pommerehne (1984), The Hidden Economy: State and Prospect for Measurement, Review of Income and Wealth 30/1, pp. 1-23.

Frey,. B.S. and H. Weck-Hannemann (1984), The Hidden Economy an "Unobserved" Variable, European Economic Review 26, 33-53.

Frey, L. (1972), Il lavoro a domicilio in Lombardia, Giunta Regionale Lombarda, Assessorato al Lavoro, Milan.

Frey, L. (1975), Il potenziale di lavoro in Italia, Documenti ISVET, no. 50.

Frey, L. (1978), Il lavoro nero nel 1977 in Italia, Tendenze della occupazione, no. 6.

Frey, L. (1980), Introduzione all'analisi economica del lavoro minorile, Economia del Lavoro, no. 1-2, 5-16.

Friedman, E., S. Johnson, D. Kaufmann and P. Zoido-Lobatón (2000), Dodging the Grabbing Hand: The Determinants of Unofficial Activity in 69 Countries, Journal of Public Economics 76/4, pp. 459-493. 
Giles, D.E.A. (1999a), Measuring the Hidden Economy: Implications for Econometric Modelling, Economic Journal 109/3, 370-380.

Giles, D.E.A. (1999b), Modelling the Hidden Economy in the Tax-Gap in New Zealand, Empirical Economics 24/ 4, 621-640.

Giles, D.E.A. (1999c), The Rise and Fall of the New Zealand Underground Economy: Are the Reasons Symmetric?, Applied Economic Letters 6, 185-189.

Giles, D.E.A. and L.M. Tedds (2002), Taxes and the Canadian Underground Economy, Canadian Tax Paper No. 106, Canadian Tax Foundation, Toronto/Ontario.

Haigner, Stefan, Stefan Jenewein, Friedrich Schneider and Florian Wakolbinger (2011), Dissatisfaction, Fear and Annoyance: Driving Forces of Informal Labor Supply and Demand, Discussion Paper, Department of Economics, University of Linz, Linz, Austria. Paper presented at the European Public Choice Meeting, Rennes, April 28 to May 1, 2011.

Hazans, Mihails (2011), Informal Workers across Europe, Evidence from 30 Countries, Discussion Paper and Background Paper, Worldbank, P112988, University of Latvia.

Heintz, E. and Chang G.B. (2007), Report of Informal Employment for the ILO, ILO Geneva.

Herwartz, H., F. Schneider and E. Tafenau (2009), One Share Fits It All? Regional Variation in the Shadow Economy in the EU Regions, Discussion paper, Universities of Linz and Kiel.

Hvidtfeldt, Camilla, Bent Jensen and Claus Larsen (2011), Undeclared work and the Danes, Universitiy Press of Southern Denmark, June 2010, English summary reported in: Rockwool Foundation Research Unit, News, March 2011, Copenhagen, Denmark.

. Institut für Demoskopie (IfD) Allensbach (1975), Freizeit Arbeit (1974), Studie im Auftrag der Kommission für Wirtschaftlichen und Sozialen Wandel, Allensbach, Bodensee.

Isachsen, A.J. and S. Strøm (1985), The Size and Growth of the Hidden Economy in Norway, Review of Income and Wealth 31/1, 21-38.

Johnson, S., D. Kaufmann and P. Zoido-Lobatón (1998a), Regulatory Discretion and the Unofficial Economy, American Economic Review, Papers and Proceedings 88 (2), 387-392.

Johnson, S., D. Kaufmann and A. Shleifer (1997), The Unofficial Economy in Transition, Brookings Papers on Economic Activity No. 2, pp. 159-221.

Johnson, S., D. Kaufmann and P. Zoido-Lobatón (1998b), Corruption, Public Finances and the Unofficial Economy, World Bank Policy Research Working Paper Series No. 2169, The World Bank, Washington, D.C.

Kanniainen, V., J. Pääkönen and F. Schneider (2004), Fiscal and Ethical Determinants of Shadow Economy: Theorey and Evidence, Discussion Paper, Department of Economics, Johannes Kepler University of Linz, Linz, Austria.

Karmann, A. (1986), Monetäre Ansätze zur Erfassung der Schattenwirtschaft: Ein Vergleich verschiedener Messansätze, Kredit und Kapitel 19, 233-247. 
Karmann, A. (1990), Schattenwirtschaft und ihre Ursachen: Eine empirische Analyse zur Schwarzwirtschaft und Selbstversorgung in der Bundesrepublik Deutschland, Zeitschrift für Wirtschaftsund Sozialwissenschaften (ZWS) 110, 185-206.

Kastlunger, B., E. Kirchler, L. Mittore and J. Pitters (2009), Sequences of Audits, Tax Compliance, and Taxpaying Strategies, Journal of Economic Psychology 30/4, pp. 405-418.

Kazemier, B. (2005a), The Undergroud Economy: A Survey of Methods and Estimates, Discussion Paper, Statistics Netherlands, Voorburg, Netherlands.

Kazemier, B. (2005b), Monitoring the Underground Labor Market: What Surveys Can Do, Discussion Paper, Statistics Netherlands, Voorburg, Netherlands.

Kazemir, B. (2006) Monitoring the Underground Economy: A Survey of Methods and Estimates, in: F. Schneider and D. Enste (eds.), Jahrbuch Schattenwirtschaft 2006/07. Zum Spannungsfeld von Politik und Ökonomie, LIT Verlag, Berlin, pp. 11-53.

Kirchgässner, G. (1983), Size and Development of the West German Shadow Economy, 1955-1980, Zeitschrift für die gesamte Staatswissenschaft /ZgS)/ Journal of Institutional and Theoretical Economics (JITE) 139, pp. 197-214.

Kirchgässner, G. (1984), Verfahren zur Erfassung des in der Schattenwirtschaft erarbeiteten Sozialprodukts, Allgemeines Statistisches Archiv 68, pp. 378-405.

Kirchler, E. (2007), The Economic Psychology of Tax Behaviour, Cambridge (UK) University Press, Cambridge.

Kirchler, E., E. Hoelzl and I. Wahl (2007), Enforces versus Voluntary Tax Compliance: The „Slippery Slope“" Framework, Journal of Economic Psychology 29/2, pp. 210.225.

Kirchler, E., B. Maciejovsky and F. Schneider (2003) Everyday Representations of Tax Avoidance, Tax Evasion and Tax Flight: Do Legal Differences Matter?, Journal of Economic Psychology 24/4, pp. 535-553.

Kopp, R.J., W.W. Pommerehne and N. Schwarz (1997), Determining the Value of Non-Marketed Goods: Economic, Psychological, and Policy Relevant Aspects of Contingent Valuation Methods, Boston, (USA), Kluwer Academic Publishing Company.

Körner, M., H. Strotmann, L.P. Feld and F. Schneider (2006), Steuermoral - Das Spannungsfeld von Freiwilligkeit der Steuerhinterziehung und Regelverstoß durch Steuerhinterzieung, IAW Forschungsbereicht Nr. 64, Tübingen.

Kucera, D. and L. Roncolato (2008), Informal Employment: Two Contested Policy Issues, International Labor Review 147/3, 321-348.

Langfeldt, E. (1984a), The Unobserved Economy in the Federal Republic of Germany, in. E.L. Feige (ed.), The Unobserved Economy, Cambridge University Press, pp. 236-260.

Langfeldt, E. (1984b), Die Schattenwirtschaft in der Bundesrepublik Deutschland, Kieler Studien 191, Mohr Siebeck Verlag, Tübingen. 
Lemieux. T., B. Fortin and P. Fréchette (1994), The Effect of Taxes on Labor Suppy in the Underground Economy, American Economic Review 84/3, pp. 231-254.

Lippert, O. and M. Walker (eds.) (1997), The Underground Economy: Global Evidences of its Size and Impact, The Frazer Insitute, Vancouver, B.C.

Loayza, N.V. (1996), The Economics of the Informal Sector: A Simple Model and Some Empirical Evidence from Latin America, Carnegie-Rochester Conference Series on Public Policy 45, 129162.

Loayza, N.V., A.M. Oviedo and L. Servén (2005a), The Impact of Regulation on Growth and Informality: Cross Country Evidence, World Bank, Policy Research Paper WPS3623, Washington, D.C.

Loayza, N.V., A.M. Oviedo and L. Servén (2005b), Regulation and Firm Dynamics, Discussion Paper World Bank, Washington D. C.

Lubell, H. (1991), The Informal Sector in the 1980's and 1990's, OECD, Paris.

Marcelli, E.A. (2004), Unauthorized Mexican Immigration, the Labour and other Lower-Wage Informal Employment in California, Regional Studies 38/1, pp. 1-13.

Marcelli, E.A., M. Pastor jr. and P.M. Joassart (1999), Estimating the Effects of Informal Economic Activity: Evidence from Los Angeles County, Journal of Economic Issues 33, 579-607.

Merz, J. and K.G. Wolff (1993), The Shadow Economy: Illicit Work and Household Production - A Microanalysis of West Germany, Review of Income and Wealth 39/2, 177-194.

Mogensen, G.V., H.K. Kvist, E. Körmendi and S. Pedersen (1995), The Shadow Economy in Demark 1994: Measurement and Results, Study No. 3, The Rockwool Foundation Research Unit, Copenhagen.

Mummert, A. and F. Schneider (2001), The German Shadow Economy: Parted in a United Germany? Finanzarchiv 58, 260-285.

OECD (2008), Declaring Work or Staying in Underground: Informal Employment in 7 OECD Countries, OECD Employment Outlook, chapter 2, OECD, Paris.

OECD (2009), Is Informal Normal? Towards More and Better Jobs, OECD, Paris.

OECD (2009), Policy Round Tables, Competition Policy and the Informal Economy, OECD, Paris.

OECD (2010), Economic Outlook Data Base, OECD, Paris.

OECD (2011), Towards a Better Understanding of the Informal Economy, written by Dan Andrews, Aida Caldera Sánchez, Asa Johansson, OECD Economics Department ,Working Papers, No. 873, OECD Publishing, Paris (2011).

Pedersen, S. (2003), The Shadow Economy in Germany, Great Britain and Scandinavia: A Measurement Based on Questionnaire Service, Study No. 10, The Rockwool Foundation Research Unit, Copenhagen.

Pickhardt, M. and J. Sardà Pons (2006), Size and Scope of the Underground Economy in Germany, Applied Economics 38/4, pp. 1707-1713. 
Posner, E.A. (2000a), Law and Social Norms, Harvard University Press. Cambridge.

Posner E.A. (2000b), Law and Social Norms: The Case of Tax Compliance, Virginia Law Review 86/6, pp. 1781-1820.

Pozo, S. (ed.) (1996), Exploring the Underground Economy: Studies of Illegal and Unreported Activity, W.E. Upjohn, Institute for Employment Research, Michigan.

Ruesga, B.S.M. (1984), Economia oculta y mercado de trabajo: Aproximación al caso espaniol, Información commercial espaniola, pp. 55-61.

Schneider, F. (1986), Estimating the Size of the Danish Shadow Economy Using the Currency Demand Approach: An Attempt, Scandinavian Journal of Economics 88/4, 643-668.

Schneider, F. (1994a), Measuring the Size and Development of the Shadow Economy. Can the Causes be Found and the Obstacles be Overcome?, in: H. Brandstaetter and W. Güth (eds.), Essays on Economic Psychology, Springer, Berlin et al., 193-212.

Schneider, F. (1994b), Determinanten der Steuerhinterziehung der Schwarzarbeit im internationalen Vergleich, in: C. Smekal and E. Theurl (eds.), Stand und Entwicklung der Finanzpsychologie, Nomos, Baden-Baden, 247-288.

Schneider, F. (1994c), Can the Shadow Economy be Reduced Through Major Tax Reforms? An Empirical Investigation for Austria, Supplement to Public Finance/ Finances Publiques 49, 137 152.

Schneider, F. (1997), The Shadow Economies of Western Europe, Economic Affairs 17, 42-48.

Schneider, F. (1998a), Further Empirical Results of the Size of the Shadow Economy of 17 OECDCountries over Time, Paper to be presented at the 54. Congress of the IIPF Cordoba, Argentina and Discussion Paper, Department of Economics, University of Linz, Linz, Austria.

Schneider, F. (1998b), Stellt das Anwachsen der Schwarzarbeit eine wirtschaftspolitische Herausforderung dar? Einige Gedanken aus volkswirtschaftlicher Sicht. Mitteilungen des Instituts für angewandte Wirtschaftsforschung (IAW) I/98, 4-13.

Schneider, F. (1999), Ist Schwarzarbeit ein Volkssport geworden? Ein internationaler Vergleich des Ausmaßes der Schwarzarbeit von 1970-97, in: S. Lamnek and J. Luedtke (eds.), Der Sozialstaat zwischen Markt und Hedeonismus, Leske und Budrich, Opladen, 126-161.

Schneider, F. (2000), The Increase of the Size of the Shadow Economy of 18 OECD-Countries: Some Preliminary Explanations, Paper presented at the Annual Public Choice Meeting, March 10-12, 2000, Charleston, S.C.

Schneider, F. (2001), Die Schattenwirtschaft - Tatbestand, Ursachen, Auswirkungen, in: A. Rauscher (ed.), Die Arbeitswelt im Wandel, J.P. Bachem, Köln, 127-143.

Schneider, F. (2003), Shadow Economy, in: C.K. Rowley and F. Schneider (eds.), Encyclopedia of Public Choice Vol. II, Kluwer Academic Publishers, Dordrecht, 286-296.

Schneider, F. (2005), Shadow Economies around the World: What Do We Really Know? European Journal of Political Economy 21/4, 598-642. 
Schneider, F. (2006), Shadow Economies and Corruption All Over the World: What Do We Really Know?, Universität Linz: Institut für Volkswirtschaftslehre, Diskussionspapier, August 2006.

Schneider, F. (2009), Size and Development of the Shadow Economy in Germany, Austria and Other OECD Countries: Some Preliminary Findings, Revue Economique 60, 1079-1116.

Schneider, F. (2010), The Influence of Public Institutions on the Shadow Economy: An Empirical Investigation for OECD Countries, European Journal of Law and Economics, 6/3, pp.441-468.

Schneider, F. (eds.), (2011), Handbook on the Shadow Economy, Cheltenham (UK), Edward Elgar Publishing Company.

Schneider, F. and D. Enste (2000a), Schattenwirtschaft und Schwarzarbeit - Umfang, Ursachen, Wirkungen und wirtschaftspolitische Empfehlungen, Oldenbourg, München.

Schneider, F. and D. Enste (2000b), Shadow Economies: Size, Causes and Consequences, Journal of Economic Literature 38/1, 73-110.

Schneider, F. and D. Enste (2002), The Shadow Economy: Theoretical Approaches, Empirical Studies, and Political Implications, Cambridge University Press, Cambridge (UK).

Schneider, F. and D. Enste (eds.) (2006), Jahrbuch Schattenwirtschaft 2006/07. Zum Spannungsfeld von Poltik und Ökonomie, LIT Verlag, Berlin.

Schneider, F. and Desiré Teobaldelli (2012), Beyond the veil of ignorance: The influence of direct democracy on the shadow economy, CESifo Working Paper MO3749, University of Munich, Munich.

Schneider, F., J. Volkert and S. Caspar (2002), Schattenwirtschaft und Schwarzarbeit: Beliebt bei vielen - Ein Problem für alle?: Eine Analyse der schattenwirtschaftlichen Aktivitäten in Deutschland (am Beispiel Baden-Württemberg) und mögliche politische Konsequenzen, Nomos, Baden-Baden.

Schneider, F., A. Buehn and C.E. Montenegro (2010), New Estimates for the Shadow Economies all over the World, International Economic Journal 24/4, pp. 443-461.

Smith, P. (1994), Assessing the Size of the Underground Economy: The Canadian Statistical Pespectives, Canadian Economic Observer, Catalogue No. 11-010, pp 16-33.

Tafenau, Egle, Helmut Herwartz and Friedrich Schneider (2010), Regional Estimates for the Shadow Economy in Europe, International Economic Journal, 24/4, pp. 629-636.

Tanzi, V. (1999), Uses and Abuses of Estimates of the Underground Economy, Economic Journal 109/3, 338-347.

Teobaldelli, D. (2011), Federalism and the Shadow Economy, Public Choice (2011) 146/3, pp. 269269.

Thomas, J.J. (1992), Informal Economic Activity, Harvester/Weatsheaf, New York et al.

Thomas, J.J. (1999), Quantifying the Black Economy: 'Measurement Without Theory' Yet Again?, Economic Journal 109, 381-389. 
Torgler, B. (2002), Speaking to Theorists and Searching for Facts: Tax Morale and Tax Compliance in Experiments, Journal of Economic Survey 16/4, pp. 657-683.

Torgler, B. (2007), Tax Compliance and Tax Morale: A Theoretical and Empirical Analysis, Edward Elgar, Cheltenham (UK), Blackwell (2009), A Meta-Analysis of Incentive Effects in Tax Compliance Experiments in J.Alm, J. Martinez, Vazquez and B. Torgler (eds.) Developing Alternative Frameworks explaining Tax Compliance, London: Routledge Publishing Company, pp. 164-181.

Torgler, B. and F. Schneider (2009), The Impact of Tax Morale and Institutional Quality on the Shadow Economy, Journal of Economic Psychology 30/3, 228-245.

United Nations (UN) (2008), Non Observed Economy and National Accounts, Survey of National Practices, United Nations, Geneva.

Weck-Hannemann, H. (1983), Schattenwirtschaft: Eine Möglichkeit zur Einschränkung der Öffentlichen Verwaltung? Eine ökonomische Analyse, Peter Lang Verlag, Bern.

Williams, C.C. (2010a), Evaluating the Nature of undeclared Work in South-Eastern Europe, Employee Relations 32/3, pp. 212-226.

Williams, C.C. (2010b), Special Variations in the hidden Enterprise Culture: Some Lessons from England, Entrepreneurship and Regional Development 22/5, pp. 403-423.

Williams, C.C. (2011a), A critical Evaluation of competing Representations of Informal Employment: Some Lessons from England, Review of Social Economy, 69/2, pp. 211-237.

Williams, C.C. (2011b), Reconceptualising Men's and Women's undecleared Work: Evidence from Europe, Gender Work and Organization, 18/4, pp. 415-437.

Williams, C.C. and J. Windebank (1998), Informal Employment in the Advanced Economies: Implication for Work and Welfare, Routledge, London.

Williams, C.C. and J. Windebank (2001a), Beyond Profit Motivated Exchange: Some Lessons from the Study of Paid Informal Work, European Urban and Regional Studies 8, 49-61.

Williams, C.C. and J. Windebank (2001b), Reconceptualizing Paid Informal Exchange: Some Lessons from English Cities, Environment and Planning A 33, 121-140. 